\title{
Structural and Igneous
}

\section{Geology of the}

\section{La Sal Mountains, Utah}

By CHARLES B. HUNT

SHORTER CONTRIBUTIONS TO GENERAL GEOLOGY

GEOLOGICAL SURVEY PROFESIONAL PAPER 294-I

With collaboration by Aaron C. Waters on the

North La Sal stock and the origin and

evolution of the magmas

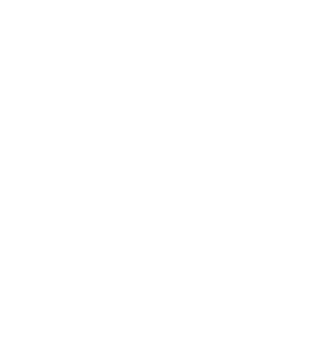

UNITED STATES GOVERNMENT PRINTING _OFFICE WASHINGTON : 1958 
UNITED STATES DEPARTMENT OF THE INTERIOR

FRED A. SEATON, Secretary

GEOLOGIGAL SURVEY

Thomas B. Nolan, Director

For sale by the Superintendent of Documents, U. S. Government Printing Office Washington 25, D. C. 


\section{CONTENTS}

Abstract.

Introduction

Previous investigations

Present investigation and acknowledgments........

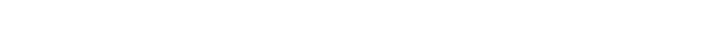

Stratigraphy

Concealed formations

Precambrian complex . . . . . . . . .

Carboniferous systems

Pennsylvanian system

Paradox member of the Hermosa formation

Hermosa and Rico formations............

Exposed formations...

Pennsylvanian and Permian systems..........

Cutler formation........

Triassic system

Lower and Middle(?) Triassic series_........... Moenkopi formation. . . . .

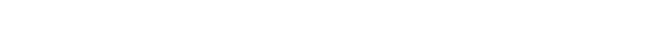
Shinarump conglomerate and Chinle formation ........

Triassic and Jurassic systems Glen Canyon group and Entrada sandstone....

Jurassic system............

Upper Jurassic series.....

Morrison formation

Cretaceous system

Lower(?) and Upper Cretaceous series......... Dakota sandstone.

Upper Cretaceous series.

Mancos shale.

Tertiary(?) system

Pliocene(?) series. . . . . . Conglomerate in Castle Valley..........

Quaternary system

Pleistocene and Recent deposits...........

Structural geology

Structural features surrounding the mountains

Details of folds adjacent to the mountains....Castle Creek anticline. Moab anticline and the Spanish Valley-Pack Creek synclines............................ Area adjacent to Middle Mountain Other folds nearby

Structure of the La Sal Mountains. ................

Relation between the La Sal Mountains and the

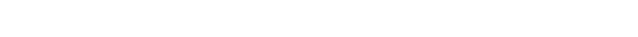

Intrusions and intrusive structures..........

Intrusions on North Mountain . . . . .

Diorite porphyry laccoliths and related intrusions................. Petrography Laccoliths southeast of the stock
Page
Intrusions and intrusive structures-Continued Intrusions on North Mountain-Continued

Diorite porphyry laccoliths and related intrusions-Continued

Laccoliths southwest of the stock ....... 320

Haystack Mountain laccolith........... 322

Mill Creek sill........................ 322

Laccoliths northwest of the stock........ 322

Laccoliths northeast of the stock........- 323

Intrusions between Willow Basin and Bear Creek . . . . . 323

Beaver Creek laccolith . . . . . . 323

Round Mountain bysmalith............. 323

Monzonite porphyry sills and dikes. . . . . 324

Petrography ....................... 324

Placer Creek sill ................ 324

Other dikes and sills.

North La Sal stock, by Charles B. Hunt and

Aaron C. Waters . . . 325

General features.......... 325

Diorite porphyry . . . . . 325

Monzonite porphyry _............. 326

Dike-swarm complex ................... 326

Feldspathoidal and other soda-rich dikes_-- $\quad 328$

Soda syenite porphyry

Explosion breccias and associated aegirine granite porphyry and aphanitic sheets...Soda rhyolite porphyry dikes............

Summary of the structural history of the North La Sal stock . . . . . . . . . . . . 333

Rock alteration on North Mountain ........... 334

Structural control of altered zones....... 334

Degree of alteration

Alteration minerals. . .

Distribution of metals............... 338

Source of the alteration products . . . . . . 339

Middle Mountain

Brumley Creek laccolith.............. 340

Dorry Canyon laccolith.......... 341

Mount Tukuhnikivatz laccolith.............. 341

Intrusions at head of La Sal Creek ... . . . . . . 341

Mount Peale laccolith....... 342

Mount Mellenthin laccoliths_...

Blue Lake laccolith . . .

Intrusions in Horse Canyon............... 344

Brumley Ridge noselite syenite porphyry ...... 344

Middle Mountain stock........ 344

South Mountain

Pack Creek laccolith . . . . _ . . . .

Laccolith southeast of the stock............ 345

Intrusions south and west of the stock........ 346

Intrusions northeast of the stock........... 346

South Mountain stock............. 346

Summary comparison of the volumes and positions of the intrusions. ... 
Origin and evolution of the magmas, by Aaron C. Waters and Charles B. Hunt

Inadequacy of crystallization differentiation of

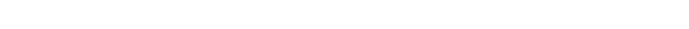

Evidence from inclusions

Palingenesis of amphibolite $\ldots \ldots \ldots$

Some physical-chemical deductions...............

Field evidence

Origin of the quartz-rich differentiate . . . . . .

Summary.

Economic geology

General

\begin{tabular}{l|} 
Page \\
348 \\
\\
348 \\
349 \\
352 \\
352 \\
353 \\
353 \\
354 \\
355 \\
355
\end{tabular}

Economic geology-Continued

Placer deposits

Metalliferous deposits in the intrusions

Mine descriptions

Dillon adit.

M. I. F. adit

High Ore adit

Dewey adit.

McCoy adit

Selected bibliography

Index.
Page

355

355

356

356

356

357

357

357

359

361

\section{ILLUSTRATIONS}

[Plates 41-44 follow page 332]

Plate 39. Geologic map of La Sal Mountains. In pocket

40. Geologic map of the North La Sal stock, La Sal Mountains

41. Aerial view of North and Middle Mountains.

42. Green Mountain vent breccia. A. Northwest edge. B. East side.

43. View northwest along the vertically sheeted joints in the south part of Beaver Basin.

44. Aerial view of Middle Mountain.

45. Maps of adits in North La Sal Mountain In pocket

Figure 105. Index map showing location of the La Sal Mountains, Utah, and other igneous centers on the Colorado Plateau.-

106. Sketch of the La Sal Mountains; view from west .

107. Generalized map of part of eastern Utah and western Colorado showing relation of the La Sal Mountains to other structural features.

108. Structure contour map of the La Sal Mountains

109. Thin sections of diorite porphyry and metadiorite

110. Thin sections of rocks from the dike-swarm complex in the North La Sal stock

111. Filter-press relations at contact between soda syenite porphyry and metadiorite in Snowslide Gulch, Mineral Mountain

112. Thin sections of soda syenite porphyry and feldspathoidal rocks, North Mountain

113. Sketch of Precambrian schist partly replaced by soda syenite porphyry

114. Vesiculated syenite porphyry from vent breccia on Green Mountain

115. Thin sections of soda rhyolite and aegirine granite porphyries

116. Thin sections of altered rocks

117. Thin sections illustrating alteration of feldspar

118. View west in Gold Basin

119. View west across cirque at head of North Fork of La Sal Creek

120. Graphs showing variations in alkali and silica content of the differentiation sequence in North Mountain.....-

\section{TABLES}

TABLE 1. Chemical analyses of diorite porphyry from the laccolithic mountains on the Colorado Plateau

2. Chemical analyses of monzonite porphyry from the iaccolithic mountains on the Colorado Plateau.............

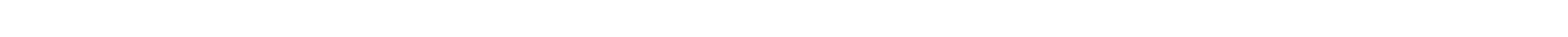

4. Estimated volumes of intrusive rock in the Henry Mountains.

5. Statistical study of 85 inclusions in diorite porphyry float in the La Sal Mountains. 


\title{
SHORTER CONTRIBUTIONS TO GENERAL GEOLOGY
}

\section{STRUCTURAL AND IGNEOUS GEOLOGY OF THE LA SAL MOUNTAINS, UTAH}

\author{
By Charles B. Hunt
}

\begin{abstract}
The La Sal Mountains, in central-eastern Utah, comprise 3 of the 15 laccolithic mountain groups on the Colorado Plateau. The mountains include 3 masses that are distinct topographically and geologically; each of the 3 consists of a stock surrounded by a cluster of laccoliths that radiate from the stock.

Sedimentary rocks exposed in the La Sal Mountains are mostly of Mesozoic age, but some are late Paleozoic. The rocks of late Paleozoic age include the highly incompetent or even plastic salt beds of the Paradox member of the Hermosa formation. The intrusives are Tertiary.

The intrusions are in the midst of a series of salt anticlines and synclines whose axes trend northwest. Although the folding and attendant faulting in the area around the La Sal Mountains are chiefly the result of late Late Cretaceous or early Tertiary deformation, the structural history is complicated because there has been repeated plastic deformation of the salt beds and the strata arched over them. These structures antedate the intrusions and are not believed to be causally related to them.
\end{abstract}

North La Sal Mountain is located on an anticline, South La Sal Mountain is in a faulted syncline, and Middle La Sal Mountain is in an area of gentle homoclinal dips between these two structures. The North La Sal Mountain forms a dome 10 miles long and 5 miles wide, and the uplift on it exceeds 6,000 feet. This dome is greatly elongated northwesterly, parallel to the axis of the anticline in which it is located. The Middle Mountain dome is nearly circular in plan, about 5 miles in diameter, and about 3,500 feet high. South Mountain dome is 6 miles long, 4 miles wide, and about 6,000 feet high. At the center of each of these domes is a stock, and radiating from each stock are laccoliths. The domes are attributed to the physical injection of the stocks. In the North and South La Sal Mountains the laccoliths spread in the salt beds of late Paleozoic age; in the Middle La Sal Mountain the laccoliths spread in shale of late Cretaceous age.

At each of the mountains the earliest intrusions were diorite porphyry and most of the laccoliths are diorite porphyry. As in the Henry Mountains, these dioritic rocks contain many amphibolite inclusions. At the North La Sal Mountain the diorite porphyry was followed by monzonite porphyry, mostly in the form of dikes and sills. In the North La Sal stock the monzonite porphyry was followed successively by a dike-swarm complex of dominantly syenitic rocks, a series of feldspathoidal dikes, and an irregular mass of soda syenite. These intrusions were accompanied by hydrothermal activity that extended outward from the stock along zones of vertically sheeted joints that had been developed in the earlier diorite porphyry laccoliths.

At this stage in the history of the North Mountain the roof over the intrusions became breached and explosion breccias developed in four major pipelike masses and in several lesser ones. These explosion breccias undoubtedly mark the roots of volcanoes. Associated with the breccias are intrusions of aegirine granite porphyry and soda rhyolite porphyry.

The field evidence and the inferred physical-chemical conditions can be interpreted to mean that the La Sal magmas did not evolve from a primary basalt by crystal differentiation. It is suggested that the magmatic sequence and hydrothermal effects could be derived by the following sequence of events:

1. Partial fusion of amphibolite or related heteromorphous metamorphic rocks to a dioritic melt containing unfused hornblende-rich remnants of the original metamorphic series.

2. Physical injection upward of the palingenetic melt, carrying suspended unfused fragments.

3. Continued melting of the leftover hornblende remnants in the substratum, changing the composition of the melt to a more alkalic and more femic liquid which, rising in the stock with attendant filtration and other differentiation, produced injections first of monzonite and then of syenite.

4. As activity waned and crystallization progressed the inerease in gas pressure in the stock blasted a series of diatremes through the arched roof.

5. Retrograde boiling of the rest magma as a result of this release of pressure developed a gaseous diffusion column in the stock and produced a silica-rich liquid represented by the aegirine granite and soda rhyolite porphyries.

\section{INTRODUCTION}

The La Sal Mountains, in eastern Utah, include 3 of the 15 laccolithic mountain groups on the Colorado Plateau (fig. 105). These 15 igneous centers seem to represent one general intrusive process that operated under very similar physical and chemical environments but was arrested at different stages of development in the mountain groups. Evidence indicates that the differences in structure and paragenesis between the five Henry Mountains, and between them and the La Plata and Navajo Mountains, are due to differences in the stage reached by the intrusive process and not to differences in depth of erosion (Hunt, C. B., 1953).

Development of this concept suggested the desirability of mapping all the laccolithic mountains on the Colorado Plateau in order to determine if they represent working models illustrating different stages in the igneous process. Comparison of the stages then would lead to better understanding of the process and perhaps provide information helpful in interpreting igneous 


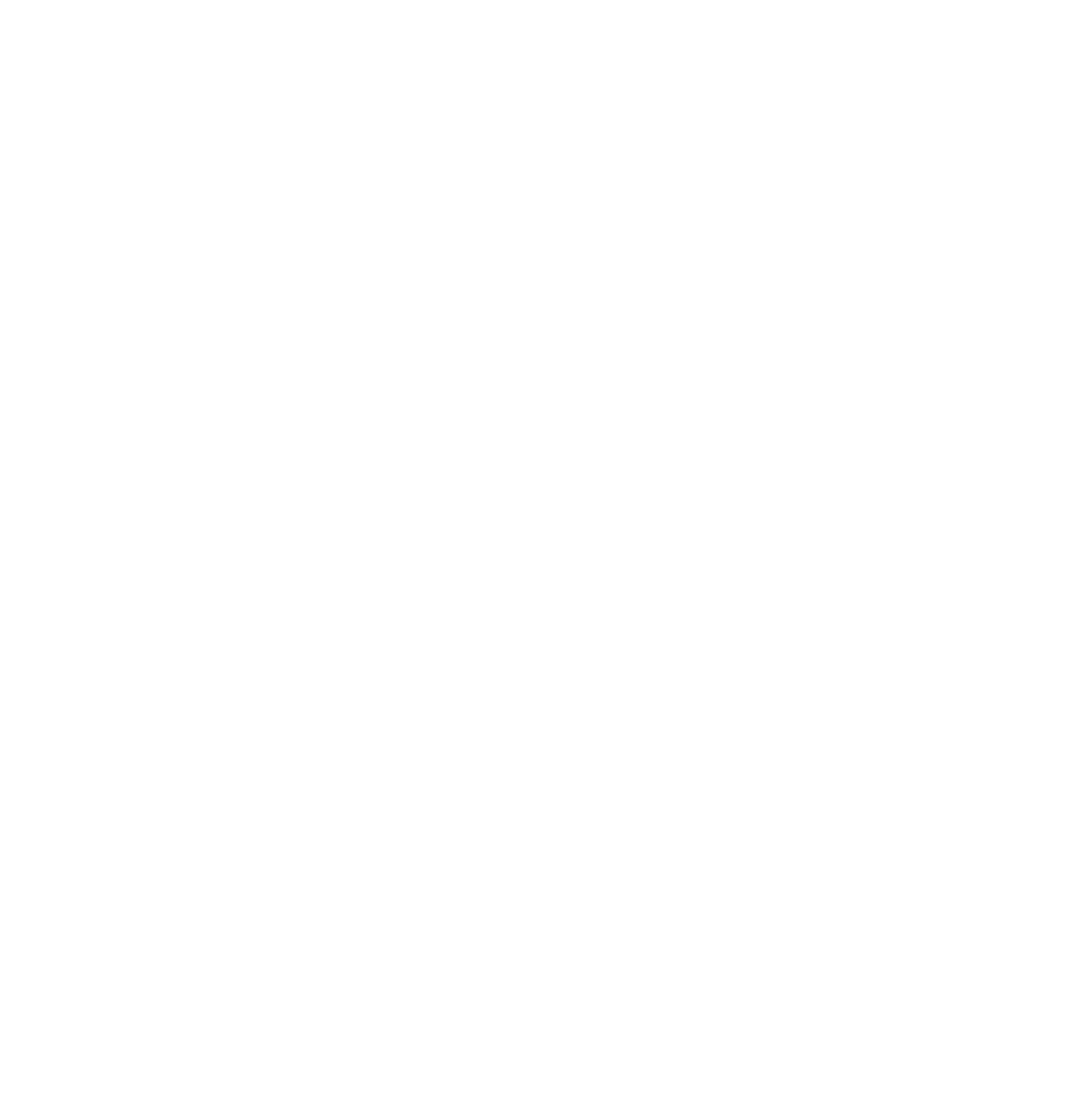

FIoure 105.-Index map showing location of the La Sal Mountains, Utah, and other igneous centers on the Colorado Plateau.

and hydrothermal phenomena in areas where the geology is more complex. This report on the La Sal Mountains is a part of that larger program.

PREVIOUS INVESTIGATIONS

The first geologic studies in the La Sal Mountains were made during the seventies under the auspices of the Hayden Survey (Peale, 1877b and 1878). This examination disclosed that the La Sal Mountains are composed of porphyry intrusions that deformed the adjacent strata.

In 1905 the mountains were visited briefly by L. M. Prindle, Whitman Cross, W. H. Emmons, G. F. Kay, and L. H. Woolsey of the U. S. Geological Survey. No formal report of their findings was published, but Prindle sampled some of the intrusive rocks and determined the presence of alkalic rocks. 
The general geology and mineral deposits of the La Sal Mountains were summarized by Hill (1913) and later by Butler (1920).

The first comprehensive study of the mountains was by Gould (1925, 1926) who confirmed the earlier inference that the mountains are laccolithic, and therefore similar to the others on the Colorado Plateau.

Other reports describing the geology of surrounding areas, or discussing problems related to the La Sal Mountains, are listed in the bibliography.

\section{PRESENT INVESTIGATION AND ACKNOWIEDGMENTS}

The fieldwork on which this report is based was done during parts of the summers of $1947,1949,1950$, and 1952. The mapping was done on contact prints of airplane photographs and transferred to a mosaic that was used for the planimetric base. The planimetry of the mosaic was corrected in part by locating about 50 land corners and comparing the surveyed distances with those measured from the mosaic.

The topographic contours for plate 39 were sketched by hasty planetable methods. Vertical angles to known points on the mountainsides were measured by alidade, and horizontal distance was measured on the mosaics as corrected in the field. The topography on the map of the North La Sal stock (pl. 40) was prepared by multiplex methods by the Topographic Division of the U. S. Geological Survey, using vertical control provided by me. The topographic survey of the La Sal Mountains represented by the topographic quadrangle maps was made after this report and accompanying maps had been prepared.

The general mapping of the mountains was completed in 1949. The seasons of 1950 and 1952 were devoted to mapping and studying the North La Sal stock.

In these studies it was my good fortune to have had visits and helpful suggestions from many colleagues. Earl Ingerson visited me in the field in 1950. Aaron Waters spent most of the 1952 field season helping to map and to interpret the North La Sal Stock.

My wife, Alice P. Hunt, managed the commissary at the field camps and conducted a companion study (1953) on the archeology of the area. G. M. Richmond is reporting on the Quaternary geology.

Fieldwork was greatly facilitated by the kindness of the local residents, especially Mr. and Mrs. Gordon Fowler. Mr. Q. D. Hanson, U. S. Forest Service, rendered many favors.

\section{GENERAL SETTING OF THE MOUNTATNS}

The La Sal Mountains are in the central part of the Colorado Plateau in eastern Utah, 10 miles from the Colorado boundary. The mountains (fig. 106) comprise three masses that are distinct topographically

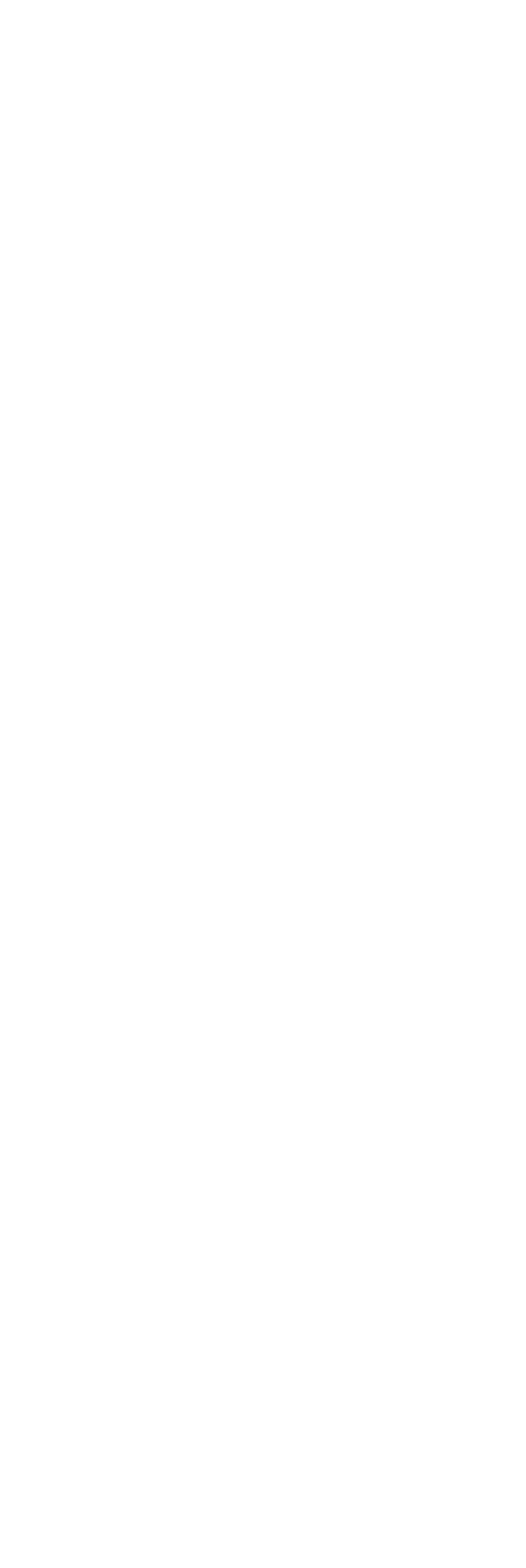




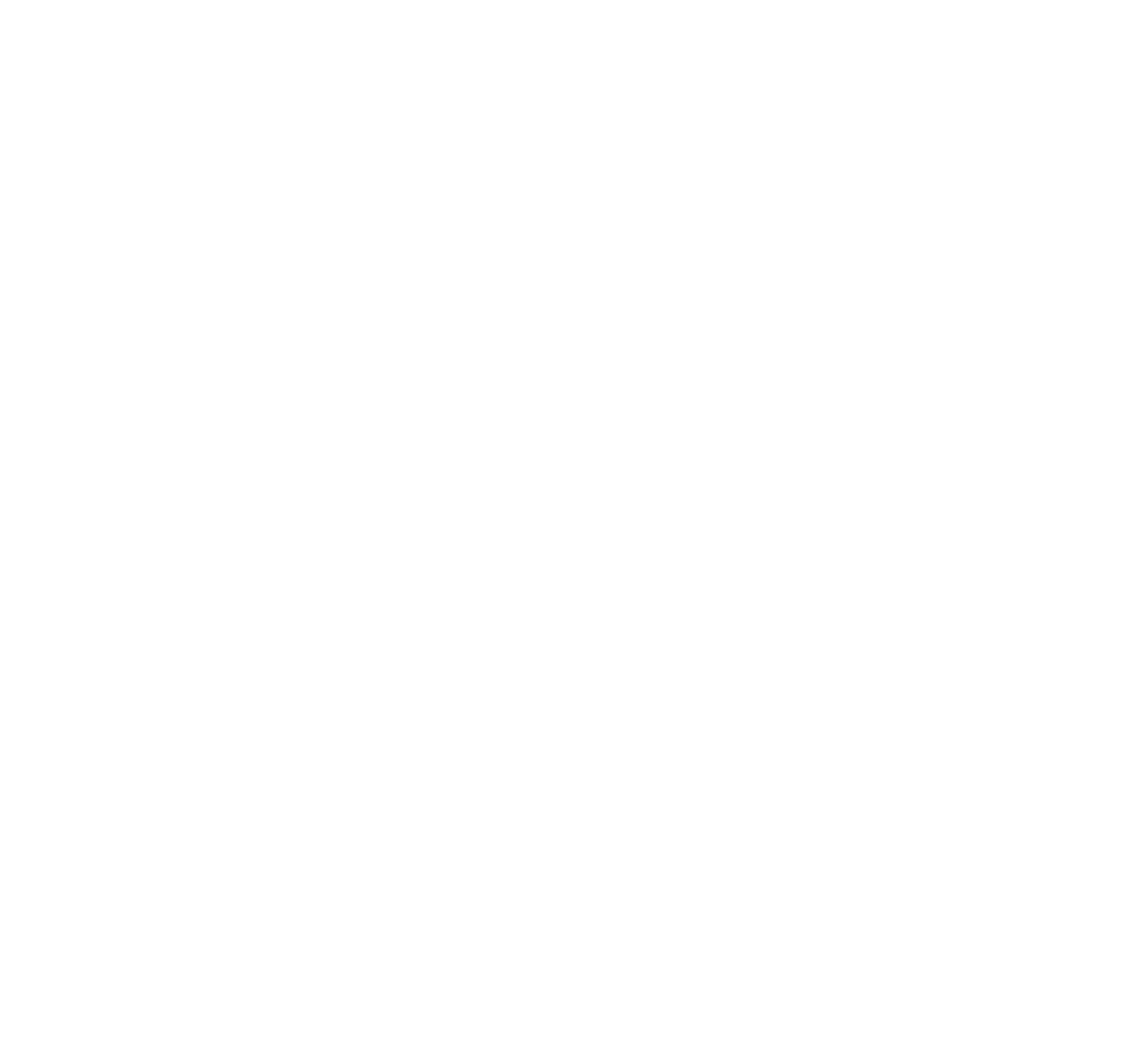

FigURE 107.-Generalized map of part of eastern Utah and western Colorado showing relation of the La Sal Mountains to other structural features (modified slightly after Dane, 1935). 
and geologically; each of the three consists of a stock surrounded by a cluster of bulbous intrusions-laccoliths whose long axes radiate from the stock.

North Mountain, the largest, has several peaks higher than 12,000 feet in altitude, and about 15 square miles of the mountain is higher than 11,000 feet. Middle Mountain has the highest peaks in the La Sal Mountains, and two of them, Mount Peale and Mount Tukuhnikivatz, reach nearly to 13,000 feet. But the area of Middle Mountain that is higher than 11,000 feet is only about half that of North Mountain. South Mountain has a single peak higher than 12,000 feet, but only about $2 \frac{1}{2}$ square miles of this mountain is higher than 11,000 feet. The three mountains are separated by passes that are slightly above 10,000 feet in altitude.

Around the foot of the mountains are the mesas and canyons so typical of the Canyon Lands section of the Colorado Plateau. The Colorado River, about 15 miles northwest of the mountains, is at an altitude of about 4,000 feet.

The higher peaks are timberless boulder fields, without vegetation except for scattered lichens. Below about 11,500 feet in altitude, however, the mountainous ridges and valleys are forested, with spruce-fir forest at high altitudes, aspen and Douglas-fir at intermediate altitudes, oak brush below this, and piñon-juniper woodland around the base. Most of the forests are open stands of timber interspersed with meadows.

The mountains were glaciated in Pleistocene time and the Pleistocene deposits are an extensive cover. Bedrock exposures are few, and most of the bedrock mapping had to be based upon float.

The La Sal Mountains are in the midst of the northwest-trending salt anticlines (fig. 107), and in this respect they are unique among the laccolithic mountains on the Colorado Plateau. The intrusions penetrated the salt beds and apparently pushed them aside. In the Middle La Sal Mountain they rose into and domed the overlying formations of Mesozoic age in the same manner as in the other laccolithic mountains of the Colorado Plateau.

\section{STRATIGRAPHY}

The sedimentary rocks exposed in the La Sal Mountains include units of late Paleozoic, Triassic, Jurassic, and Cretaceous age. In addition there are extensive surficial deposits of Quaternary age and one moderately well consolidated gravel deposit that probably is of late Tertiary age. The intrusive rocks probably are Tertiary.

Because of poor exposures in the mountains, the bedrock sedimentary formations have not been subdivided as finely as they have been in the adjacent parts of the plateau where exposures generally are excellent. Indeed, the 20 or so formations and members that have been mapped in adjoining areas are grouped into only 4 mappable units in parts of the mountains.

At most places the Triassic and older rocks have been grouped together for mapping. Locally individual formations of Triassic, Permian, or Pennsylvanian age can be identified, but the boundaries between them cannot be distinguished consistently enough to warrant mapping them over large areas.

The Glen Canyon group and the lower part of the San Rafael group comprise five distinguishable formations in adjoining areas, but these have been grouped together into a single mappable unit in the mountains. The Wingate, Navajo, and Entrada sandstones are conspicuous cliff formers in the canyons of southeastern Utah but they are not at all well exposed in the La Sal Mountains. Here they are thoroughly fractured by joints as a result of folding, and during the Pleistocene they were largely reduced to rubble by frost action. Nowhere in the mountains do these sandstone formations form extensive cliffs; in fact, few outcrops of them are satisfactory for measuring strikes and dips.

Around the base of the mountains the Morrison and related formations are reasonably distinctive, but in most of the La Sal Mountains these deposits are shown as a single unit, locally including, at the top of the formation, some sandstone beds that belong to the Dakota.

Overlying the Morrison formation is the Mancos shale. A conglomerate in Castle Valley may be late Pliocene in age.

Only meager data are available about the thickness and kind of rocks that underlie the exposed formations. In adjoining areas more than 3,500 feet of sedimentary rocks of late Paleozoic age lie between the Precambrian basement and the Triassic formations (Dane, 1935, p. 19-20). The upper part of these formations of Paleozoic age consists of interbedded competent sandstone and incompetent shale beds, but the lower part constitutes the thick highly incompetent gypsum and saltbearing Paradox member of the Hermosa formation.

The rock formations that were penetrated by the intrusions, so far as they are known, are summarized in the table below. 
Rock formations cut by the intrusions in the La Sal Mountains

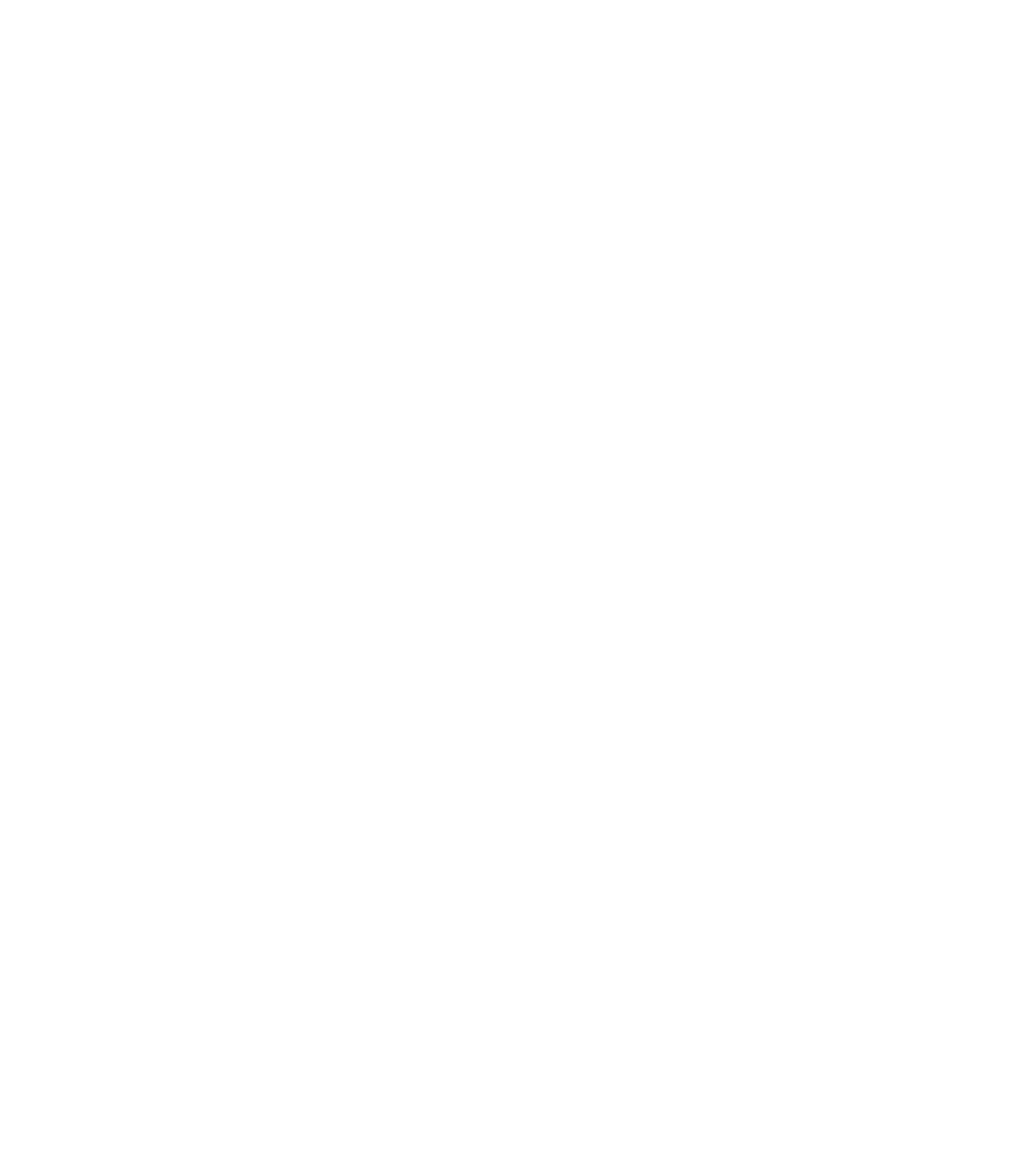


Rock formations cut by the intrusions in the La Sal Mountains-Continued

\begin{tabular}{|c|c|c|c|c|c|c|c|}
\hline & System & Series & Group & Formation & Member & Thickness (feet) & Description of rocks \\
\hline \multirow{4}{*}{ 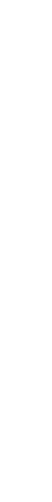 } & $\begin{array}{l}\text { Permian and } \\
\text { Pennsylvanian }\end{array}$ & & & $\begin{array}{c}\text { Cutler } \\
\text { formation }\end{array}$ & & $1,000 ?$ & $\begin{array}{l}\text { Largely red sandstone, well-bedded and } \\
\text { thinly bedded. Moderately competent } \\
\text { unit. On the map this unit is included } \\
\text { with the Triassic and older formations. }\end{array}$ \\
\hline & \multirow{3}{*}{ 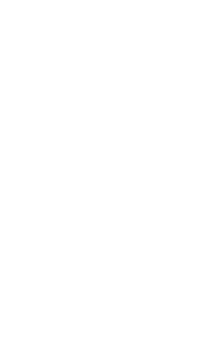 } & & & $\begin{array}{c}\text { Rico } \\
\text { formation }\end{array}$ & & $200 ?$ & $\begin{array}{l}\text { Sandstone, conglomerate, and limestone. } \\
\text { Grades laterally into lower part of Cutler } \\
\text { formation and may not be a separate } \\
\text { formation beneath La Sal Mountains. } \\
\text { Competent unit. }\end{array}$ \\
\hline & & & & $\begin{array}{r}\text { Hermosa } \\
\text { formation }\end{array}$ & & $1,500 ?$ & $\begin{array}{l}\text { Limestone, sandstone, and shale; marine. } \\
\text { Moderately competent unit. }\end{array}$ \\
\hline & & & & & $\begin{array}{l}\text { Paradox } \\
\text { member }\end{array}$ & $1,000+$ & $\begin{array}{l}\text { Sandy shale, sandstone, dense gray lime- } \\
\text { stone, black shale, gypsum, and rock salt } \\
\text { Plastic unit. }\end{array}$ \\
\hline & $?$ & $?$ & $?$ & $?$ & $?$ & $?$ & $?$ \\
\hline & Precambrian & & & & & & $\begin{array}{l}\text { Granite, granite gneiss, biotite schist, horn- } \\
\text { blende schist, and amphibolite. }\end{array}$ \\
\hline
\end{tabular}

\section{CONCEALED FORMATIONS}

PRECAMBRIAN COMPLEX

Exposures of Precambrian rocks nearest to the La Sal Mountains are about 25 miles to the northeast in the Uncompaghre Plateau. Here the Precambrian rocks include strongly foliated biotite gneiss, hornblende and biotite schist, and coarsely crystalline biotite granite with associated pegmatitic phases (Dane, 1935, p. 20-24). The coarsely crystalline granite is cut by stringers and dikes of finer grained granite. Pegmatite veins cutting the granite consist mostly of pink feldspar and a smaller proportion of quartz in masses almost as large as the feldspar. The granite contains microcline but no plagioclase, less quartz than feldspar, and less than 10 percent of biotite, chlorite, and muscovite (Dane, 1935, p. 21-22).

Fine-grained biotite gneiss, locally containing small garnet porphyroblasts, is interlayered with hornblendequartz schist. Also present is a garnetiferous biotitehornblende gneiss, abundantly injected with quartz and pegmatite, the latter locally containing considerable black tourmaline (Dane, 1935, p. 22-23).

The Precambrian rocks in the San Juan Mountains (Cross, Howe, and Irving, 1907, p. 1) and in the Gunnison River region (Hunter, 1925) are similar to those in the Uncompahgre Plateau.

The Precambrian rocks are important to the geology of the intrusions in the La Sal Mountains in several ways. In the first place their foliation in the Uncompahgre Plateau is oblique to the axis of that plateau and to the axes of the anticlines in the vicinity of the La Sal Mountains. This foliation and related structures in the Precambrian rocks in some way must have controlled the locations of the laccolithic mountains-far more so, at least, than the obvious structures in the sedimentary formations at the surface which do not seem to have affected the distribution of the igneous centers on the Colorado Plateau (Hunt, 1956, p. 63). Second, the Precambrian rocks are much more competent structurally than the overlying sedimentary formations, and this probably is why the intrusions crosscut the Precambrian rocks with little or no lateral spreading in them (Hunt, C. B., 1953, p. 142). Third, the xenoliths of Precambrian granite, gneiss, and schist in the diorite porphyry may provide some clues about the nature and origin of the amphibolite inclusions in the porphyry (p. 349; Hunt, 1953, p. 164). Finally, it may be more than coincidence that alkalic rocks occur in the Precambrian (Cross and Larsen, 1935, p. 24) as well as in the La Sal Mountains.

\section{CARBONIFEROUS SYSTEMS \\ PENNSYLVANLAN GXSTEM \\ PARADOX MEMBER OF THE HERMOSA FORMATION}

The Paradox member of the Hermosa formation, of Pennsylvanian age, is a thick sequence of highly incompetent-indeed plastic - salt, gypsum, limestone, sandstone, and petroliferous shale. Under the salt anticlines the formation is at least 1,000 feet thick and has given rise to many salt plugs. Castle Valley northwest of North Mountain and Spanish Valley northwest of South Mountain are examples (Baker, 1933). The Paradox member may be underlain by older sedimentary formations, but these probably are thin and in structural behavior probably can be included with the highly competent Precambrian complex.

Whereas the Precambrian formations are thought to have controlled the locations of the stocks, the Paradox member of the Hermosa formation was important in 
controlling the position and structural forms of the laccoliths in the La Sal Mountains. The formation was approximately as plastic as the intrusions, which bulged laterally where they passed from the underlying competent rocks into this thick series of incompetent ones.

Black shale and thin beds of limestone, probably belonging to the Paradox member of the Hermosa formation, are exposed along the distal edge of the intrusion south and west of the South Mountain stock (p. 346), at several localities along the edges of intrusions south and east of the North Mountain stock (p. 312), and on the flanks of Round Mountain in Castle Valley (p. 323). Near Round Mountain, 1,000 feet from the intrusion, the shale is petroliferous but near the contact it is not obviously so, perhaps because of distillation near the intrusion.

\section{HERMOSA AND RICO FORMATIONS}

Neither the Hermosa, excluding the Paradox member, nor the Rico formation was identified in the mountains. Considerable limestone, arkosic sandstone, and gray or greenish shale is exposed in contact with the intrusions along the southwest flank of South Mountain and along the southwest and northeast flanks of North Mountain. Small inliers of similar sediments are found locally at the edges of intrusions in the interior of North Mountain. These may belong to the Hermosa or Rico. Their total thickness probably is no more than a very few hundreds of feet. In adjoining areas the Rico is 500 feet thick and the Hermosa is 1,800 feet thick (Baker, 1933, p. 18-29). In the La Sal Mountains the Rico may be represented by red beds similar to the Cutler and the Hermosa may be thin because of erosion before the deposition of the Chinle formation.

\section{EXPOSED FORMATIONS}

PENNSYlvantan AND PERMtan systems

CUTLER FORMATION

West and north of the La Sal Mountains the Cutler formation consists of purple and red sandstone, purple conglomerate, and sandy shale (Baker, 1933, p. 29-33; Dane, 1935, p. 38-41). The formation has a maximum thickness of about 1,000 feet near the mountains but thins across the tops of the large anticlines.

Sandstone and conglomerate, probably belonging to the Cutler formation, are exposed in South and North Mountains. Their total thickness is no more than a few hundred feet, perhaps because the two mountains are located along extensions of the Spanish Valley and Castle Creek anticlines. On the map (pl. 39) the Cutler is included with the Triassic and older formations.
TRIASSIC SYSTEM

LOWER AND MIDDLE(?) TRLASSIC SERIES MOENKOPI FORMATION

Well-bedded red sandstone, siltstone, and shale typical of the Moenkopi formation is exposed in South and North Mountains. The thickness, estimated about 500 feet, is uncertain because incomplete exposures make it difficult to determine the upper and lower boundaries of the formation.

West of the mountains the Moenkopi locally is missing, being cut off by an unconformity (Baker, 1933, p. 35). The formation may similarly be missing locally in the La Sal Mountains.

North and west of the mountains the Cutler and Rico formations locally were similarly removed by erosion before the deposition of the Moenkopi, as shown by an angular unconformity at the base of the Moenkopi.

\section{UPPER TRIASSIC SERIES}

SHIN ARUMP CONGLOMERATE AND CEINLE FORMATION

The Shinarump conglomerate has not been identified in the mountains. Locally there is a thin conglomerate containing well-rounded quartz pebbles that may represent the Shinarump.

The Chinle formation is the only one of the Triassic and older formations that has been identified with reasonable certainty within the mountains. It is composed of variegated and thinly but irregularly bedded shale, sandstone, and conglomerate. Colors range from green, gray, and brown to red and purple. In the mountains these beds are about 300 feet thick and form a distinctive slope at the base of the thick series of overlying sandstone.

Most of the laccoliths in the North and South Mountains spread in the Triassic and older formations, mostly at or below the base of the Chinles.

\section{TRIASSIC AND JURASSIC SYSTEMS}

GLEN CANYON GROUP AND ENTRADA SANDSTONE

The Wingate sandstone, Kayenta formation, and Navajo sandstone, constituting the Glen Canyon group, and the overlying Entrada sandstone were mapped together in the mountains. They have an aggregate thickness of more than 1,000 feet. In the plateaus adjoining the mountains these four formations are fairly distinctive. In the mountains, however, these rocks have been thoroughly fractured by structural deformation and so disrupted by frost heaving that it was not feasible to map them separately; at most places the boundary between these sandstones and the overlying lower part of the Morrison formation is difficult to identify. 
The Wingate sandstone, which overlies the Chinle formation, consists of about 300 feet of red sandstone in beds ranging from a few feet to 50 feet or so thick. Its outcrop is a jumble of broken blocks of massive sandstone 2 to 5 feet across. The sand is fine grained; individual grains are mostly less than 0.25 millimeter in diameter and well rounded. The sandstone, which is more resistant than the underlying Chinle formation, forms a steep rocky slope above Chinle.

Overlying the Wingate sandstone is the Kayenta formation, which consists of about 250 feet of thinly bedded red, purple, and brown sandstone. The sand is fine grained, rather like the Wingate, and can be distinguished most easily by the thin bedding and purple coloring. The outcrop generally is covered by large blocks of sandstone moved downslope from adjoining sandstones.

About 300 feet of Navajo sandstone in thick massive beds overlies the Kayenta formation. The texture is similar to that of the Wingate and Kayenta, but the colors are lighter, commonly gray or buff, and the thick massive beds yield boulders a few feet in diameter. Outcrops of the sandstone are few, but the trace of the belt of outcrops is marked by boulder fields.

Above the Navajo is the Entrada sandstone, about 275 feet thick. Like the Navajo, it is massive and gray or buff and weathers in large boulders. It can be distinguished by the fact that the sand grains locally are of two sizes, the larger being $1 / 2$ to 1 millimeter in diameter; the smaller are less than 0.2 millimeter in diameter.

The Wingate, Kayenta, and Navajo have gradational boundaries. If outcrops were more complete, perhaps red shale or sandstone of the Carmel formation could be recognized.

These sandstones constitute a highly competent unit. All the laccoliths in the La Sal Mountains spread either below these sandstones or above them; none spread within them.

\section{JURASSIC SYSTEM \\ UPPER JURASSIC SERIES MORRISON FORMATION}

In the La Sal Mountains the Morrison formation can be divided into three parts: the lower part, composed dominantly of sandstone, is about 300 feet thick; the middle part, composed mostly of shale, is about 375 feet thick; the upper part, composed mostly of sandstone, is about 150 feet thick. The upper part includes beds that may be Early Cretaceous in age.

Only in the Middle Mountain was the attempt made to map these parts separately. Because of poor exposures the Dakota sandstone, which locally is 150 feet thick, has been included with the Morrison on the map (pl. 39). If the Summerville formation is present in the La Sal Mountains, it too has been included with the Morrison.

The total thickness of the Morrison formation, including the beds at the top which properly are Dakota, is nearly 1,000 feet. Structurally, the lower part belongs with the competent unit composed of the underlying Entrada sandstone and Glen Canyon group.

The middle part of the Morrison formation is the first thick set of incompetent beds above the Paradox member of the Hermosa formation and is the host for most of the laccoliths in Middle Mountain and for some in North Mountain.

The upper part of the Morrison is a competent unit consisting mostly of sandstone but including some shale. On Middle Mountain the upper part contains considerable limestone and a rather distinctive black chert pebble conglomerate. In the head of Hell Canyon the limestone beds are 20 feet thick. Wherever the limestone occurs, it invariably contains chert in irregular nodules and veins. The limestone is lenticular but seems to be present in most parts of Middle Mountain. The black chert pebble conglomerate also is lenticular; it occurs in closely spaced lenses a foot or two thick and several feet long. West of the La Sal Mountains similar beds have been regarded as Dakota sandstone (Baker, 1933, p. 55).

\section{CRETACEOUS SYSTEM \\ LOWER(?) AND UPPER CRETACEOUS SERIES \\ DAKOTA SANDSTONE}

At a few localities, especially on Middle Mountain, the Dakota sandstone is sufficiently well exposed to be identified separately from the upper part of the Morrison formation. Such localities, however, are so few and widely spaced that no attempt was made to map the Dakota as a separate formation.

In the head of Horse Canyon the Dakota sandstone is about 60 feet thick. At the top is 10 feet of tan well-bedded sandstone. Below this is 50 feet of carbonaceous shale, lenses of carbonaceous or tan sandstone, and a 14-inch bed of shaly coal.

An unconformity separates the Dakota and Morrison formations but structurally the Dakota is part of the competent unit that includes the upper part of the Morrison.

\section{UPPER CRETACEOUS SERIES MANCOS SHALE}

The Mancos shale, the youngest of the formations of Mesozoic age preserved in the mountains, probably had an original thickness of 2,000 to 3,000 feet, and most or all of it must have been part of the overburden above the intrusions. Only a few hundred feet of the shale is preserved today. This shale is black, organic 
rich, and fissile. About 250 feet above the base is a zone of limestone concretions and about 600 feet above the base is a friable tan sandstone, the Ferron sandstone member, which is 150 feet thick west of the mountains (Baker, 1933, p. 55).

The Mancos shale, a distinctly incompetent unit, was host for several of the laccoliths on Middle and North Mountains.

\section{TERTIARY(P) STSTEM}

PLIOCENE(?) SERIES

\section{CONGLOMERATE IN CASTLE VALLEY}

The conglomerate in Castle Valley contains fragments derived from the North Mountain intrusions. It was deposited as a fill in the upper part of Castle Valley and has a thickness of several hundred feet, possibly exceeding 1,000 feet. The formation is exposed best at the northwest base of North Mountain in the upper part of Castle Valley.

Pebbles in the conglomerate include the typical diorite, monzonite, and syenite porphyry comprising the intrusions on North Mountain, including their hydrothermally altered facies, and red, brown, and gray sandstone apparently derived from the Glen Canyon, Triassic, and older units. No shale identifiable as having been derived from the Mancos shale or middle part of the Morrison was found. The conglomerate clearly is younger than the intrusions, and the absence or at least scarcity of fragments of the Mancos shale and Morrison formation suggests that those formations had already been stripped off the top of the North Mountain dome when the conglomerate was deposited.

The conglomerate is coarse and bouldery near the foot of North Mountain; some of the boulders are 2 to 4 feet in diameter. Northwestward the formation becomes less coarse. Two and a half miles southeast of Round Mountain, on a cliff face 10 by 10 feet, 5 boulders 12 to 18 inches in diameter were counted. A representative square foot of this surface contains 30 cobbles 1 to 3 inches in diameter; 90 percent of these cobbles are diorite porphyry. The pebbles are rather angular, but the edges and corners are rounded.

The conglomerate is very well stratified; individual beds are mostly 1 to 2 feet thick. Lenses of coarse arkosic sand separate the layers of conglomerate. Near the foot of the mountains these lenses are few and are mostlyless than 6 inches thick but northwestward they become thicker and more numerous.

The conglomerate is well indurated, but contains little clay or calcium carbonate. The fresh rock effervesces only slightly with dilute hydrochloric acid.

No fossils were found in the conglomerate. It is assumed to be late Pliocene in age, or possibly very early Pleistocene. The steeply dipping beds of the conglomerate (p. 315) are beveled by the pediment of which Harpole Mesa is a remnant; this pediment is overlain by two bouldery pre-Wisconsin deposits that presumably are glacial outwash.

The induration and deformation suggest considerable antiquity and the overlying soils indicate an age no younger than early Pleistocene. On the other hand, the conglomerate seems to have been formed after the Morrison and Mancos had been removed from above the North Mountain intrusions and after Castle Valley had been formed; very likely, therefore, the conglomerate is considerably younger than the intrusions.

\section{QUATERNARY SYSTEM}

\section{PLATSTOCENE AND RECENT DHPOSITS}

Pleistocene and Recent deposits on the mountains include moraines, glacial outwash, alluvium, boulder fields, colluvium, some eolian, and some residual deposits. These deposits are of some interest in connection with the structural history of the area because some of them are faulted, presumably because of salt movement during Quaternary time (p. 315).

\section{STRUCTURAL GEOLOGY}

\section{STRUCTURAL FEATURES SURROUNDING THE MOUNTAINS}

The La Sal Mountains are in the midst of a series of faulted anticlines and synclines whose axes trend northwest (fig. 107). These structures parallel the anticlinal axis of the Uncompahgre Plateau, a huge uplift almost 100 miles long and 25 miles wide, located 25 miles northeast of the La Sal Mountains. The area of anticlines and synclines around the La Sal Mountains coincides with the basin in which the thick salt and related sediments of the Paradox member of the Hermosa formation were deposited.

The folding and attendant faulting in the area around the La Sal Mountains are chiefly the result of late Cretaceous or early Tertiary deformation as shown by the folding of the formations of late Mesozoic age. But the structural history is complicated by the fact that there has been repeated plastic movement of the salt, at least locally. Also, there was uplift of the Uncompahgre Plateau and some of the anticlines near the La Sal Mountains at the time the Cutler and Moenkopi formations were being deposited (Baker, 1933, p. 77, 78; Dane, 1935, p. 149, 155; Prommel and Crum, 1927b; Harrison, 1927). These structures antedate the intrusions in the La Sal Mountains, which probably are middle Tertiary in age; besides, there locally has been late Tertiary and Quaternary deformation due to flowage of the salt. 
The regional structures materially influenced the shape of the igneous intrusions, but a genetic relationship between the orogenic structures and intrusions is doubted. The laccolithic mountains on the Colorado Plateau generally seem to have been independent of the regional structures (Hunt, C. B., 1953).

The foliation of the Precambrian in the Uncompahgre Plateau and in the Needle Mountain region in Colorado generally trends east, with variations to a few degrees east of north (Dane, 1935, p. 22). This foliation is oblique to the younger structures like the Uncompahgre Plateau and the anticlines in the vicinity of the La Sal Mountains.

\section{DETAILS OF FOLDS ADJACENT TO THE MOUNTAINS} CASTLE CREEK ANTICLINE

The Castle Creek anticline (fig. 107) is a southeasttrending fold about 25 miles long. The dome at North Mountain forms the southeast part of the anticline and the structural relief across this part of the fold is more than 6,000 feet (fig. 108). The anticline flattens southeast of the North Mountain dome but extends 12 miles northwest of it.

Northwest of North Mountain the anticline has a maximum structural relief of about 3,000 feet, but the axis plunges northwest and the anticline flattens where it crosses the Colorado River (Baker, 1933, p. 61-62). Near the center of the anticline is a plug of diorite porphyry, Round Mountain (pl. 39), which is intruded into shale of the Paradox member of the Hermosa formation. The shale dips steeply away from the walls of the plug; small remnants of the shale roof are preserved on top of it. The plug perhaps is a bysmalith (p. 323).

Gypsiferous masses of the Paradox member of the Hermosa formation form hills along the two sides of Castle Valley between Round Mountain and the northwest foot of North Mountain. These are the tops of salt plugs of the Paradox member which has been thrust upward into the anticline. The Rico and Hermosa do not crop out in Castle Valley; the Paradox has been thrust upward to the stratigraphic position of the Cutler.

Between these salt plugs and between the igneous intrusions at Round Mountain and North Mountain is a trough that is occupied by the conglomerate in Castle Valley, which is thought to be late Pliocene in age (p. 314). The conglomerate has been downfolded into a structural basin having smooth flanks. The northwest, north, and northeast flanks of the basin $\operatorname{dip} 10^{\circ}$ to $15^{\circ}$ inward, but towards the southeast the dips progressively steepen until they are vertical at the northwest foot of the laccoliths in Grand View Mountain.
The fact that this conglomerate in Castle Valley has been folded shows that there was deformation of the Castle Creek anticline since the North Mountain intrusions were formed, for these igneous rocks were the source for the conglomerate. Presumably this deformation was due to flowage of salt, for the salt plugs are along the edges of the basin occupied by the conglomerate. This interpretation presents some difficulties, however, because the structural basin produced in the conglomerate has very smooth flanks, and it is difficult to visualize so orderly a structure resulting from salt movement. Elsewhere in this region salt flowage has developed faulting and irregular slumping (Baker, 1933, p. 79, 80). But whatever the mechanics of the process, the date of the deformation is postigneous intrusion and probably Quaternary. It is equally clear that the conglomerate was deposited in an anticlinal valley and that major deformation had occurred there before the conglomerate was deposited.

The high dome around North Mountain was formed when the igneous intrusions became emplaced, and this dome represents further uplift on an anticline that had formed before the igneous intrusions.

\section{MOAB ANTICLINE AND THE SPANISH VALLEY-PACK CREEK SYNCHNNES}

The Moab anticline and the Spanish Valley-Pack Creek synclines (fig. 107) are a series of contiguous structures whose southeast-trending axes are alined with the axis of the South Mountain dome. They have been mapped and described by Baker (1933, p. 63-67).

The most northwesterly of these structures, and the most instructive for interpreting the structural history, is the Moab anticline. This anticline is about 18 miles northwest of South Mountain but is contiguous with the Spanish Valley-Pack Creek synclines which extend from it to the South Mountain dome. Baker described the history of the Moab anticline as follows (1933, p. 65):

The initial stage in the folding of the Moab anticline occurred at the end of the Permian epoch, after normal deposition of the Paradox, Hermosa, Rico, and Cutler formations. The folded strata were eroded, and the Cutler, Rico, and part of the Hermosa formations were removed from the crest of the anticline. After the deposition of the Moenkopi formation upon the beveled edges of the older formations further folding occurred at the end of Moenkopi time. The Moenkopi formation was removed by erosion at the crest of the anticline, and the underlying Hermosa formation was further eroded. The elevated surface due to the post-Moenkopi folding was eroded only in part before the deposition of the Upper Triassic Chinle formation, which overlaps the older beds. $* * *$ Post-Chinle formations were deposited across the anticline and folded during later periods $* * *$.

The Spanish Valley-Pack Creek synclines lie along a faulted monocline; near the middle of Spanish Valley the formations southwest of the synclines are 1,500 feet higher than they are on the northeast. This dis- 
placement decreases towards the South Mountain dome; a mile from the base of that dome the displacement across the synclines is only about 500 feet. Part of the decrease in displacement is due to a series of faults trending southwest from the synclines (fig. 107); on most of these faults the downthrow is to the southeast. In the region surrounding the La Sal Mountains numerous other faults trend at right angles to the folds.

Near the base of the South Mountain dome the Mancos shale is involved in the infolded, downfaulted synclines, and records a stage in the deformation no older than late Late Cretaceous time.

Southeast of South Mountain, along La Sal Creek in the southern part of T. $28 \mathrm{~S}$., R. $25 \mathrm{E}$., is a prominent southeast-trending escarpment composed of the Morrison formation, which probably is the result of faulting. This belt is alined with the synclinal structures northwest of South Mountain and may be a continuation of them. The South Mountain dome is elongated parallel to and alined with these structures.

\section{AREA ADJACENT TO MIDDLE MOUNTAIN}

Middle Mountain is in the area of smooth homoclinal dips between the Castle Creek anticline and Pack Creek syncline. Several normal faults are at the west base of the Middle Mountain dome and many others farther to the northwest. Most of these trend northwesterly parallel to the regional folds. The area east of Middle Mountain has not been mapped, but reconnaissance there revealed no major folds or faults.

\section{OTHER FOLDS NEARBY}

Other faulted belts that are near the La Sal Mountains are illustrated in figure 107. Of these, Paradox Valley, in westernmost Colorado, is by far the largest. It is a northwest-trending fault valley, 25 or 30 miles long, and directly on line with the Castle Creek anticline and long axis of the North Mountain dome. The northwest end of Paradox Valley is only about 4 miles from the southeast edge of the North Mountain dome, but if the structures connect at all, they seem to do so along small folds or small faults.

About 7 miles east of North Mountain, at Sinbad Valley, is a similar structural feature, also trending northwest.

Ten miles north of North Mountain and 5 miles northeast of the Castle Creek anticline is the faulted Onion Creek anticline.

About 8 miles south of South Mountain, at Lisbon Valley, is another northwest-trending and faulted anticline.

All these are faulted salt anticlines or related structures, and their history probably is similar to that of the Moab anticline.

\section{STRUCTURE OF THE IA SAL MOUNTAINS}

Each of the three La Sal Mountains is a structural dome that is several miles in diameter and several thousand feet high (fig. 108). The North Mountain dome, the largest and highest, is 10 miles long and 5 miles wide, and the uplift on it exceeds 6,000 feet. The dome is greatly elongated in a northwest direction parallel to the Castle Creek anticline, of which it is the southeastern part.

The Middle Mountain dome is smallest and most symmetrical. It is nearly circular in plan, about 5 miles in diameter, and about 3,500 feet high.

The South Mountain dome, about 6 miles long and 4 miles wide, is as high as the one at North Mountain, but its area is much smaller. The long axis of the South Mountain dome trends northwest parallel to and alined with the faulted synclines that extend northwest from it.

At the center of each of these domes is a stock, and radiating from each stock are the laccoliths. Evidence has been presented elsewhere to show that the large mountain domes of the laccolithic mountains on the Colorado Plateau are the result of physical injection of the stocks at their centers (Hunt, C. B., 1953, p. 139). The La Sal Mountains are quite like the other laccolithic mountains in that the degree of doming is proportional to the diameters of the stocks, and, if the domes were flattened, the space occupied by the stocks would be closed.

The cover of sedimentary formations that once extended across the tops of the intrusions in the North and South Mountains has largely been removed by erosion. It is not possible, therefore, to reconstruct the original configuration of the upper parts of those domes, but presumably they were wrinkled with anticlines whose axes radiated from the stock, as on the Middle Mountain dome and at the Henry Mountains.

The laccoliths around the stocks on North and South Mountains spread in the pre-Triassic formations, presumably mostly in the very incompetent Paradox member of the Hermosa formation. The Paradox member is known to be thick and near the surface under the Castle Creek anticline. The Paradox member also is thick under the Moab anticline but is not known to be thick beneath the Spanish Valley-Pack Creek synclines, although the fact that they are much faulted suggests that they too are or were underlain by salt beds. The laccoliths that spread in the salt are even larger and more bulbous than is the typical laccolith in the Henry Mountains; their volume commonly exceeds a cubic mile. Moreover, these laccoliths are in contact with one another or separated by only very thin layers of the sedimentary rocks; the plastic beds have been squeezed from between the igneous intrusions. 


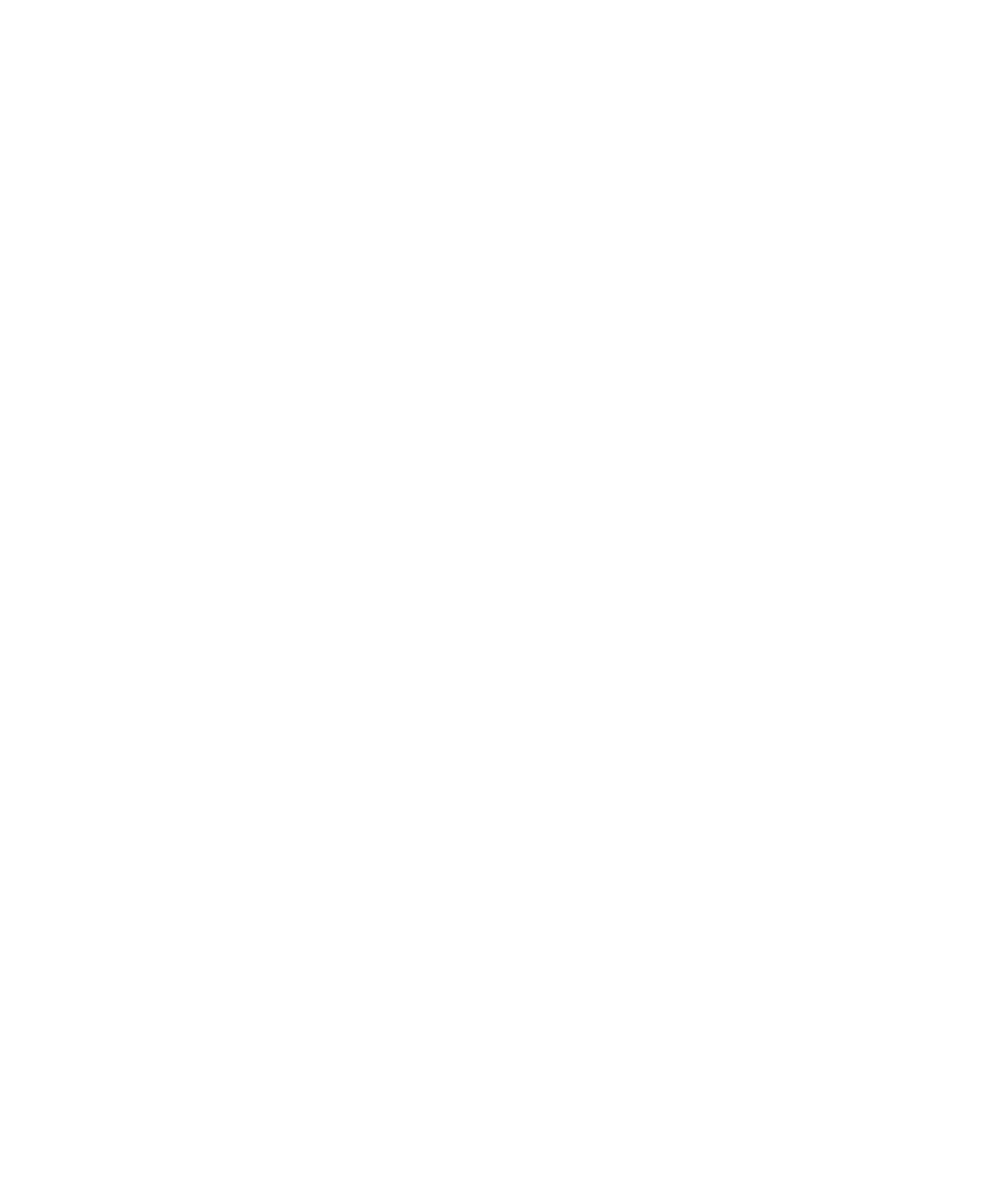

FIGURE 108.-Structure contour map of the La Sal Mountains, Utah. 
The laccoliths that formed at North Mountain evidently pushed the salt northwestward and may have produced the salt plugs that extend northwestward from the foot of that mountain.

On Middle Mountain the laccoliths spread in the Morrison formation and Mancos shale and did not spread in the Paradox member of the Hermosa formation as did those on North and South Mountains; perhaps the Paradox is very thin beneath Middle Mountain. At any rate, the intrusions rose through the Paradox member to the uppermost Jurassic and Upper Cretaceous formations which are the next higher, thick, and incompetent formations. The upper surface of the dome at Middle Mountain resembles those of the Henry Mountains in having anticlines over the laccoliths radially arranged about the stock. The smoothness of the flanks of the Middle Mountain dome and the fact that it is only 3,500 feet high clearly show that it is not underlain by buried laccoliths of considerable size.

RELATION BETWEeN THE LA SAL MOUNTANN AND THE REGIONAL STRUCTURES

The laccolithic mountains on the Colorado Plateau are distributed at random among the regional structural features of the plateau and seemingly without any relation to them. Because no two of the mountain groups have the same structural setting, little genetic significance can be attached to the fact that the intrusions of the La Sal Mountains are in the midst of a series of faulted folds (Hunt, 1956, p. 63).

A lack of relationship between the stocks in the La Sal Mountains and the surrounding structures is suggested by the very different setting for each of the stocks. The North La Sal stock rose into an anticline that became enlarged as a result of the intrusion, the Middle La Sal stock crosscut homoclinally dipping formations between folds, and the South La Sal stock rose into a faulted syncline.

Gould cited reasons for believing that the anticlines either preceded the intrusions or were contemporaneous with them (1926b, p. 119-129. No doubt the anticlines are earlier (p. 315). But, although the stocks and folds do not seem to be genetically related, the folds did affect the location and shape of the laccoliths. Both at North and South Mountains, for example, the laccoliths are much elongated parallel to the structures that were invaded.

\section{INTRUSIONS AND INTRUSIVE STRUCTURES}

\section{INTRUSIONS ON NORTH MOUNTAIN}

The intrusions on North Mountain consist of a central stock surrounded by laccoliths, sills, dikes, and other minor intrusive forms. The intrusions that parallel the axis of the Castle Creek anticline are greatly elongated (pl. 41). Most of the laccoliths are composed of diorite porphyry. A few are composed of monzonite porphyry and are younger than the diorite porphyry laccoliths.

Structurally the laccoliths are of three kinds. One set, intrusive into the Paradox member of the Hermosa formation, consists of very large irregular laccoliths that extend 4 miles southeast of the stock and 4 miles northwest of it. A second set that intrudes the Paradox extends northeast and southwest from the stock; these are short blunt intrusions that are only about 1 mile long. These two sets of laccoliths differ from those in the Henry Mountains in being much more bulbous and irregular, and practically all sedimentary rock has been excluded from between the individual intrusions.

The third set of North Mountain laccoliths was injected from the stock 2 to 3 miles northeastward and southwestward across the regional structure and into the incompetent beds of the Morrison formation and Mancos shale. These laccoliths are quite like those in the Henry Mountains.

The relative ages of these three sets has not been definitely determined, but their structural arrangement suggests that the set in the Paradox member of the Hermosa formation northwest and southeast from the stock is the earliest, and that the set intruded across the regional structure and into the Morrison formation and Mancos shale is the youngest. The short blunt laccoliths in the Paradox member in general overlie and appear to be shingled on the flanks of the first set of laccoliths. The structurally higher set in general is judged to be younger because this position involves the least amount of overburden to be raised. Moreover, it seems likely that initial spreading of the diorite porphyry into the sedimentary rocks would be favored in the directions parallel to the axis of the anticline that was invaded; later spreading across the structures would occur when the axial directions had become clogged.

The laccoliths in the Morrison formation and Mancos shale are thought to be the youngest set of diorite porphyry laccoliths because, with the possible exception of the Haystack Mountain laccolith, they are younger than much of the doming around North Mountain. The Mill Creek sill, for example, south of Warner Ranger Station and on Boren Mesa, cuts across 300 feet or so of strata in about $1 \frac{1}{2}$ miles. In the next mile northeastward, however, the strata rise $75^{\circ}$ to $80^{\circ}$ onto the southwest flank of the North Mountain dome. Because the sill is not turned up with these strata, the discordance must increase greatly across them. The coincidence of this increase in discordance at the hinge line of the fold strongly suggests that the intrusion is younger than the fold and was injected across it. Other 
laccoliths in the Morrison and Mancos are not similarly exposed, but, except at Haystack Mountain, none shows an escarpment facing the mountain; therefore they seem to have been injected upward and outward from the mountain.

The North La Sal stock is composed very largely of syenite porphyries but includes highly altered remnants of the earlier diorite porphyry stock that fed the laccoliths. No remnants of monzonite porphyry have been found in the stock, but the cutting of some of the monzonite porphyry intrusions by syenite porphyry shows that the syenite is younger.

The earliest syenite porphyry is represented by a dike swarm that was intruded along the eastern edge of the altered diorite porphyry stock (pl. 40). Development of the dike swarm ended with the intrusion of some feldspathoidal dikes, and these were followed by the intrusion of a larger mass of soda-rich syenite porphyry into the diorite porphyry.

The roof of the stock then became breached, and explosion breccias developed in pipelike masses that undoubtedly led upward to volcanoes. Intrusive into these breccias, but partly involved in the brecciation, are small masses of aegirine granite porphyry and aphanitic lavalike masses. The igneous activity at North Mountain ended with the intrusion of a few dikes of soda rhyolite porphyry that cut across the explosion breccias.

\section{DIORITE PORPHYRY LACCOLITHS AND RELATED INTRUSTONS PETROGRAPHY}

Diorite porphyry, which makes up about 5.5 cubic miles, or about 75 percent of the intrusive rocks in North Mountain, forms most of the laccoliths and part of the stock.

Hand specimens of the rock show equidimensional phenocrysts of plagioclase and elongate crystals of hornblende in a gray groundmass. In the fine-grained varieties the phenocrysts may be as small as 2 or 3 millimeters. Most of the varieties are coarser and contain phenocrysts as much as 10 millimeters in diameter. Within any one intrusion the coarseness of the texture seems to be fairly uniform except for minor chilling or cataclastic effects within a few feet of the contacts, but separate intrusions differ in their texture. Most of the intrusions show some flow banding.

Thin sections of the diorite porphyry (fig. 109) show plagioclase phenocrysts constituting about 30 percent of the rock. They have sharp crystal faces but many have rounded corners and edges. The cores are of sodic andesine or calcic oligoclase but the outer zones are oligoclase or even albite.

The mafic phenocrysts, constituting about 15 percent of the rock, are mostly common hornblende, but
A

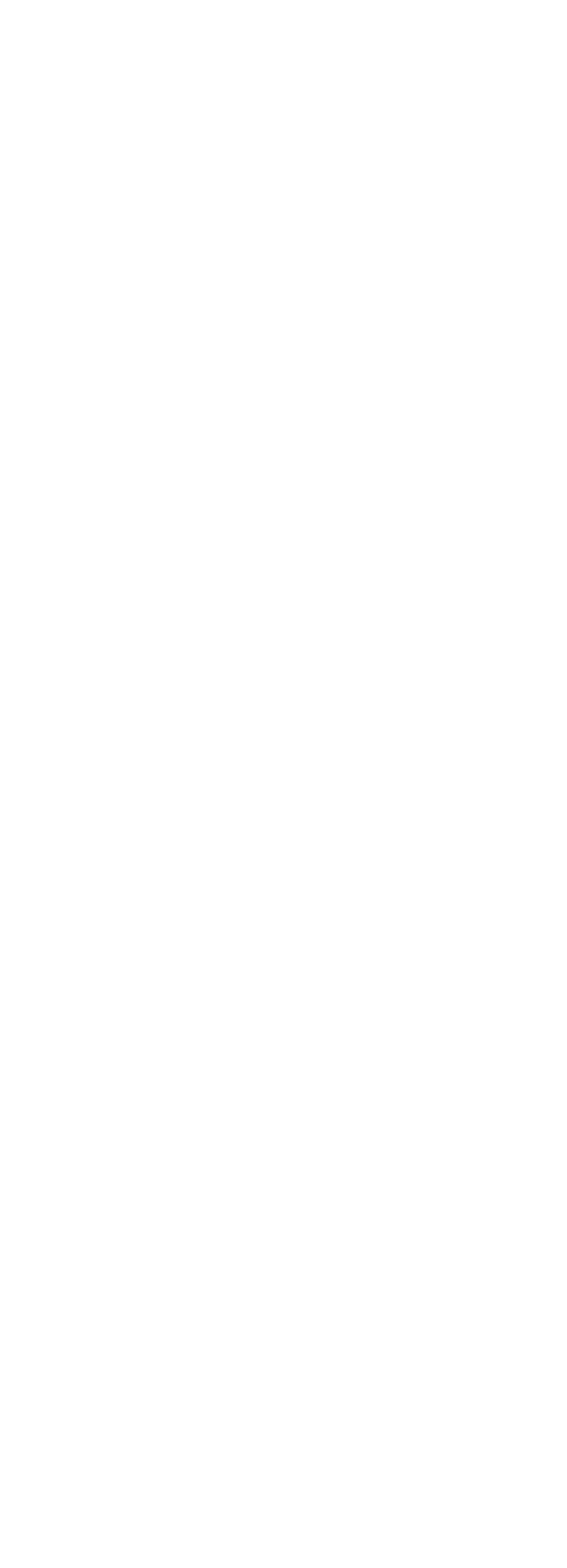

FrGURE 109,-Thin sections of diorite porphyrv and metadiorite. Diameter of fields about $2 \mathrm{~mm}$. $A$. Porphyry very slightly altered if at all, Mount Tomasaki. Euhedral phenocrysts of oligoclase (o), hornblende (h), and magnetite (m) in microcrystalline feldspathic groundmass. $\boldsymbol{B}$. Moderately altered porphyry, Dorry Canyon laccolith. Rounded phenocrysts of oligoclase (o) have argillized borders and partly sericitized interiors. Pyroxene (p) largely altered to magnetite and calcite. $\mathrm{m}$, magnetite phenocrysts. $C$. Severely altered porphyry, Oregon Park. The rounded phenocrysts of oligoclase (o) are argillized, and in plane light they are indistinguishable from the argillized microcrystalline feldspathic groundmass. Quartz phenocryst (q) partly resorbed. No mafic minerals remain, and irregular areas of the groundmass are stained with limonite (1). $D$. Metadiorite, North La Sal stock. The feldspar (an) in part is sodic oligoclase (or albite) and dusty sodic orthoclase or anorthoclase(?). The groundmass is coarsely crystalline anhedral feldspar. Feldspar phenocrysts have ragged outlines and in plane light are indistinguishable from the groundmass. ac, actinolite and hedenbergite. 
locally include minor amounts of aegirine-augite or biotite. These phenocrysts have sharp crystal faces but their ends commonly are irregular and rounded.

Other common minerals are magnetite (less than 5 percent) and apatite and sphene (together less than 1 percent).

The groundmass makes up roughly 50 percent of the rock and is in part a cryptocrystalline or microcrystalline aggregate of orthoclase, albite, quartz, and oligoclase.

The occurrence of phenocrysts in the chilled contacts of the diorite porphyry intrusions indicates that crystallization of the porphyry had begun before the magma became emplaced in the sedimentary rocks.

The diorite porphyry contains about 1 percent of inclusions of amphibolite that are composed of the same feldspar and mafic minerals as occur in the porphyry. These are described on page 349 .

Table 1 gives some chemical analyses of diorite porphyry from the laccolithic mountains on the Colorado Plateau.

\section{IACCOUITHS SOUTHEAST OF THE STOCK}

The laccoliths extending southeasterly from the the stock on North Mountain include the masses of porphyry, mostly diorite porphyry, that form the high ridge, including Mount Tomasaki and Manns Peak, that forms the south wall of the valley of Deep Creek.

The intrusions were injected from the stock southeastward for 4 miles into the Paradox member of the Hermosa formation. Flanking the intrusions are beds that may be Pennsylvanian in age, but, if these beds are Pennsylvanian, they must be out of position, for there is not space enough between them and the Glen Canyon group for the complete stratigraphic section to be represented. Very possibly the beds are out of position because of preintrusion flowage of salt, such as occurred along Castle Creek anticline northwest of North Mountain (p. 315).

The axes of the laccoliths trend south of east. The north and south flanks are smooth and dip about $50^{\circ}$. The southeast or distal end is smoothly rounded and somewhat steeper than the sides.

The floor of the laccoliths is not exposed, nor are there good exposures of the side contacts. There are small patches of baked sedimentary rocks, probably remnants of the roof, preserved in the saddle northwest of Mount Tomasaki and on each side of the saddle just east of the peak. These are 600 feet lower than the peak, which is composed of porphyry and perhaps represents a bulge in the roof. The ridge a mile east of Mount Tomasaki may be a similar bulge in the roof; this one is elongate parallel to the axis of the laccolith. Irregularities of this sort are common and well exposed in the roofs of the laccoliths in the Henry Mountains.

On the north side of the laccolith are two cirques that expose a prominent set of joints roughly parallel to the axis of the intrusion. Flow banding in the porphyry also parallels the axis. This flow banding is original, but the joints probably are younger and related to later stages of deformation around the stock. (See p. 334.)

In the saddle between Mount Tomasaki and Manns Peak and along the north flank of the laccolith, the diorite porphyry has been hydrothermally altered and leached of its mafic minerals, including the amphibolite inclusions. Specular hematite and some epidote have formed in the porphyry and the altered rock is cut by a few quartz veins a few inches wide. These altered zones extend southeastward along two zones of joints in the north flank of the laccolith. Another, less welldeveloped, zone of alteration extends along the south flank of the laccolith. Both the extent and degree of alteration diminish eastward; at its east end the laccolith is composed of perfectly fresh, unaltered porphyry. This alteration probably occurred when the dike-swarm complex and soda syenite porphyry were intruded in the stock (p. 326-331).

The intrusions at Manns Peak and on the ridge that divides the head of Mill Creek from Beaver Basin probably are separate from those in the vicinity of Mount Tomasaki. This interpretation assumes that the sheeted zone of hydrothermally altered diorite porphyry crossing the ridge between Manns Peak and Mount Tomasaki was localized along the contact between the intrusions. The intrusions at Manns Peak are bounded on the west by a sill of monzonite porphyry. Their distal end lies under the turned up Triassic and older rocks along the southwest flank of the North Mountain dome.

These laccoliths southeast of the stock are 4 miles long, $1 \frac{1}{2}$ miles wide, and as much as 2,500 feet thick along their axial bulge. Their aggregate volume is estimated to be about 1.25 cubic miles.

\section{IACCOLITHS SOUTHWEST OF THE STOCK}

Between Wet Fork and Placer Creek is a considerable mass of diorite porphyry that probably represents more than one laccolith pushed into and ended against the Triassic and older formations forming the steep southwest flank of the North Mountain dome. These intrusives are separated from those at Manns Peak by a zone of hydrothermally altered, steeply dipping joint sheets, including some altered monzonite porphyry.

The porphyry at Oregon Park is a laccolith that was injected westward from the stock into the Paradox member of the Hermosa formation and apparently along 
STRUCTURAL AND IGNEOUS GEOLOGY OF THE LA SAL MOUNTAINS, UTAH

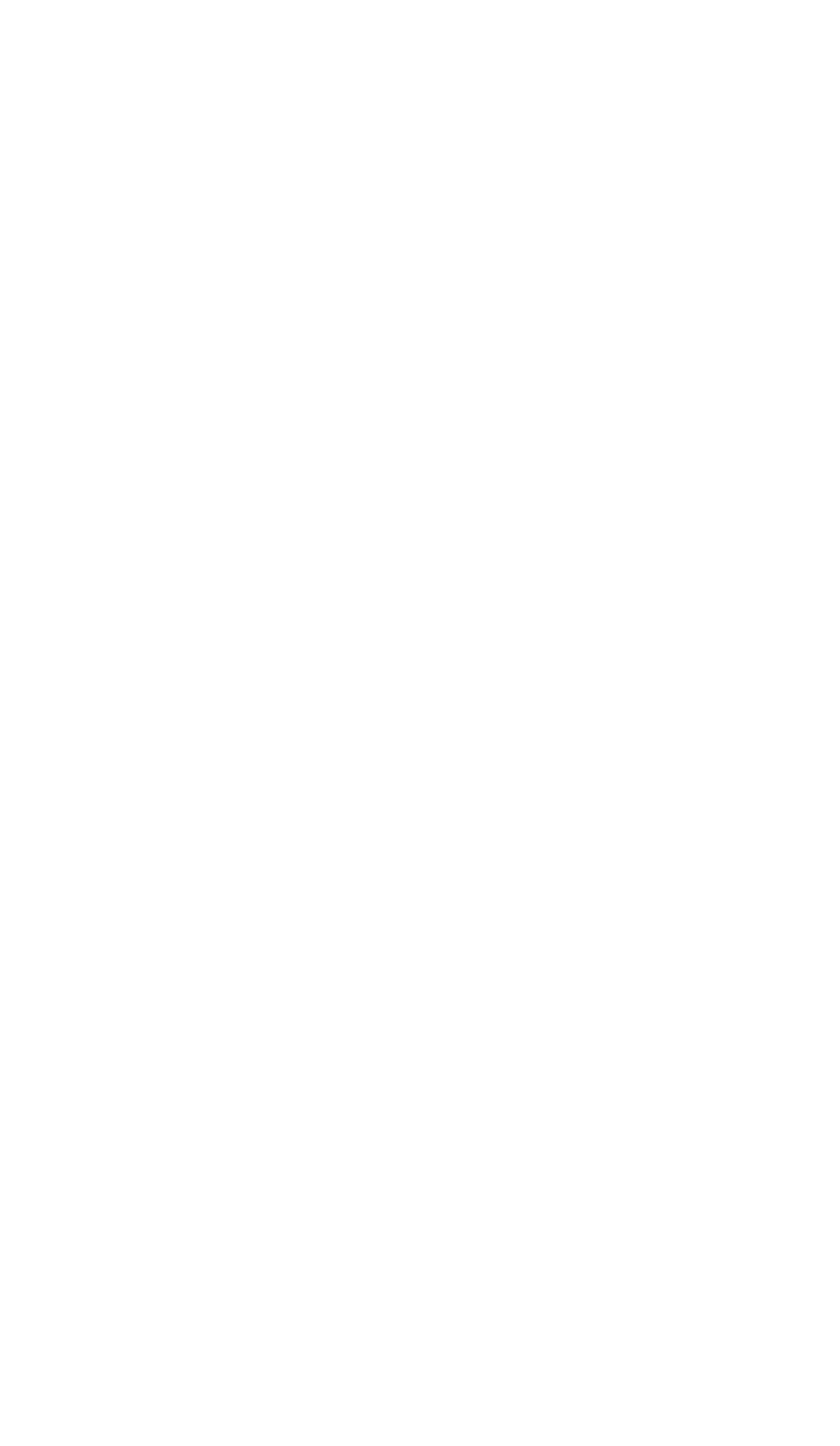


the south flank of the laccolith on the south side of Horse Mountain. A sheet of monzonite porphyry, however, was subsequently injected along the contact between these two laccoliths and now separates them. The floor of one of the laccoliths southwest of the stock is along Placer Creek, where it is mostly concealed by glacial moraine and other Pleistocene deposits. It is exposed at one place on the north side of the creek, where the diorite porphyry rests on the sedimentary rocks that form the roof of the sheet of monzonite porphyry. Both the sediments and the floor of the laccolith dip south into the creek. The position of Placer Creek evidently was controlled by this contact zone.

Along Schuman Gulch is a belt of altered sheeted rocks that includes patches of sedimentary rocks. I suspect that this belt marks the boundary between separate intrusions. Patches of sedimentary rocks, probably of Pennsylvanian age and representing remnants of the roof rocks, are preserved along the ridge between Schuman Gulch and Placer Creek. Along this ridge and on the slope into Placer Creek, the porphyry is little altered.

The distal ends of these laccoliths are in the Triassic and older formations turned up in the steep southwest flank of the North Mountain dome. They are 1.5 to 2 miles long, $2 \% / 4$ miles wide, and 1,200 to 2,500 feet thick along their axial bulges. Their volume must aggregate 1.25 cubic miles.

\section{HAYSTACX MOUNTANN LACCOIITH}

The Haystack Mountain laccolith is one of the set that intrudes the Mancos shale and lies outside the steep flank of the North Mountain dome. The floor of the laccolith dips with the strata about $30^{\circ}$ to $40^{\circ}$ $\mathrm{SW}$. Locally the lower part of the diorite porphyry is sheeted roughly parallel to the floor; in the $\mathrm{NW}^{1 / 4} \mathrm{NW}^{1 / 4}$ sec. 35 the sheets strike N. $60 \mathrm{~W}$. and dip $30^{\circ} \mathrm{SW}$. Flow banding in these sheets roughly parallels the floor but at Burro Pass the flow banding is oblique to a vertical set of joints and dips $30^{\circ} \mathrm{NW}$.

A few hundred feet west of Burro Pass the Mancos shale at the floor of the laccolith is baked to hornfels for a distance of 50 feet or so below the floor. Along the east side of the laccolith, shale 20 feet from the contact is unaltered, although the nearby porphyry has slickensides and has been altered by leaching of the hornblende.

No roof rocks are preserved on the Haystack Mountain laccolith. The floor contact was not found exposed but its position could be determined within a few feet at several places and could be followed with reasonable certainty by observing float.
The laccolith covers about 1 square mile and has a maximum thickness of about 1,200 feet. Its volume is only about 0.1 cubic mile.

\section{MHLL CREEK SIII}

The Mill Creek sill, like the Haystack Mountain laccolith, is in the Mancos shale outside the North Mountain dome. The sill extends southwestward from the vicinity of the Warner Ranger Station across Mill Creek and the west end of Boren Mesa.

Mill Creek has cut through the sill along the north side of Boren Mesa. Northeast of the creek the sill is in the upper part of the Morrison formation, or Dakota sandstone, but southwestward it cuts to higher strata. At its southwest end on Boren Mesa the sill is about 50 feet thick and is about 50 feet above the base of the Mancos shale. The roof here rises $5^{\circ}$ to $10^{\circ}$ northeastward. The shale on the roof is baked to hornfels for 10 feet above the porphyry, but higher strata are not altered. In the upper surface of the porphyry are grooves 6 feet deep parallel to the axis of the intrusion. Similar features are common on the roofs of the laccoliths in the Henry Mountains (Hunt, C. B., 1953, fig. 56).

The sill is exposed as a narrow sheet, 2 miles long, about 1,000 feet wide, and 50 to 100 feet thick. It was intruded discordantly through the steep southwest flank of the North Mountain dome (p. 316) and must extend another 2 miles to the northeast to connect with the stock. Its total volume, however, is negligible compared with the volume of the other intrusions on North Mountain and probably does not exceed 0.02 cubic mile.

LACCOIITHS NORTHWEST OF THE STOCK

Horse Mountain and Grand View Mountain, which form the northwest end of North Mountain, are composed of porphyry that probably represents more than one laccolith. The porphyry extends $3 \frac{1}{2}$ miles northwestward from the stock and is $1 \frac{1}{2}$ miles wide. At the northwest foot of Grand View Mountain are two small porphyry bodies that probably represent separate intrusions.

Along the northeast side of Horse Mountain, the laccoliths are overlain by Triassic formations. These and the overlying sandstones of the Glen Canyon group rise $45^{\circ}$ onto the northeast side of the laccolith and form the roof of the intrusion.

On the southwest side of Horse Mountain, the laccoliths are overlain by the sheet of monzonite porphyry that separates these intrusions from the Oregon Park laccolith. The thin layers of sedimentary rocks that are present locally at the contact may include some 
beds of Pennsylvanian age, but these beds probably were raised out of position by salt flowage before the igneous intrusions.

Conglomerate, containing Precambrian pebbles and cobbles, and probably representing the Cutler formation, is exposed between Battle-ground and Harpole Mesa. This conglomerate dips south of west away from the laccoliths which in this area, therefore, are in or below the Cutler formation.

Extending 3 miles northwestward is the conglomerate of Pliocene(?) age in Castle Valley, which contains gravels and boulders eroded from these laccoliths. Exposures of the conglomerate begin about threequarters of a mile northwest of the base of Grand View Mountain; the conglomerate there is vertical. The dip, however, diminishes northwestward and flattens along the west line of T. 25 S., R. 24 E. From there conglomerate rises gently onto the salt domes in sec. 25 of the adjoining township. Although the conglomerate in Castle Valley appears to have been turned up steeply against the distal end of the laccolith in Grand View Mountain, probably the conglomerate was synclinally folded as a result of flowage of salt from below it long after the intrusion was emplaced. (See p. 315.)

The laccoliths northwest of the stock aggregate at least 3,000 feet in thickness, and their total volume probably is 1.5 cubic miles.

\section{IACCOLITHS NORTHEAST OF THE STOCK}

Extending almost due north from the stock is a laccolith of diorite porphyry that discordantly cuts across the Triassic and most of the Jurassic formations along its west wall, which is along a fault in the lower part of Bachelor Basin. The laccolith also cuts upwards through the Triassic and Glen Canyon group on the west side of the northernmost peak, but a considerable body of porphyry must extend under that peak because the formations there are structurally 2,000 feet or more higher than they are in Bachelor Basin. At least one sill extends southeastward from the main intrusion into the tilted sandstone formations.

Contacts along the north and distal end of this laccolith are concealed, but that part of the intrusion apparently is in the lower part of the Morrison formation.

Near the stock the diorite porphyry is cut by sodarich syenite dikes.

Diorite porphyry, which underlies the monzonite porphyry forming the summit of Mount Waas, cuts across the Triassic formations in the head of Bear Creek and extends eastward at the base of the Glen Canyon group to Beaver Creek. Still a third mass of diorite porphyry extends into the head of Deep Creek under the Triassic formations.

A zone of hydrothermally altered sheeted joints is taken as the boundary between these intrusions and those extending southeastward from the stock.

These intrusions on the northeast side of the stock probably aggregate about 0.8 cubic mile.

\section{INTRUSIONS BETWEEN WLLIOW BASIN AND BEAR CREEK}

The sill at the east rim of Willow Basin is in the upper part of the Morrison formation. Its roof is concordant; its base is not exposed. The thickness is no more than 500 feet and may be only about 100 feet.

This sill may be a satellite of the laccoliths in the Paradox member. Its volume must be small.

Along the west side of Bear Creek is a northeasttrending dikelike ridge of diorite porphyry in the Mancos shale. No exposed contacts were found around it. The intrusion may extend westward and connect with the sill on the rim of Willow Basin. If so, the exposed part is a linear bulge on the roof of a broad sheetlike intrusion. Probably it is a separate intrusion that rises northeastward from or under the laccoliths in the Paradox member.

\section{BEAVER CREEK IACCOLITH}

The Beaver Creek laccolith forms a high ridge between Bear and Beaver Creeks in the northwest part of T. $26 \mathrm{~S}$., R. $25 \mathrm{E}$. This laccolith is in the Mancos shale; its concordant roof is exposed along Bear Creek on the distal end of the intrusion.

The laccolith is 3 miles long, one-half mile wide, and at least 600 feet thick. Its volume probably is about 0.15 cubic mile.

\section{ROUND MOUNTAIN BYSMALTTH}

Round Mountain, a plug of diorite porphyry in the middle of Castle Valley $4 \frac{1}{2}$ miles northwest of Grand View Mountain, probably is a bysmalith. On top of the porphyry are remnants of the concordant shale roof preserved in swales that trend northwest. On the south side of the plug is exposed an almost vertical contact between the porphyry and adjacent sediments that dip steeply away from the intrusion, which is slightly elongated in a northwesterly direction.

It seems likely that Round Mountain is a bysmalith having steep side contacts along which the roof has been faulted upward. The intrusion is flanked and capped by shale of Pennsylvanian age, presumably of the Paradox member of the Hermosa formation. The bysmalith may be the swollen distal end of a sheetlike or pipelike intrusion in the salt beds, extending northwest from the North La Sal stock. 


\section{MONZONITE PORPHYRY SILLS AND DIKES}

PETROGRAPHY

Monzonite porphyry, constituting somewhat less than 10 percent of the intrusive rocks in North Mountain, forms several sills and dikes that radiate from the stock. At one time the stock must have contained monzonite porphyry, but no remnants of this porphyry have been recognized in it.

Hand specimens of the monzonite porphyry generally show equidimensional phenocrysts of plagioclase, tabular phenocrysts of potash feldspar, and hornblende, pyroxene or biotite, and a little quartz. The phenocrysts generally are larger than in the diorite porphyry; they commonly are 10 millimeters in diameter and may be 15. These are set in a paste that usually is somewhat darker gray than that of the diorite prophyry. The phenocrysts commonly are alined in a crude flow structure.

A typical thin section of the monzonite prophyry contains about half and half of phenocrysts and groundmass. Oligoclase phenocrysts, around $\mathrm{An}_{15}$, constitute about 40 percent of the rock; perthite phenocrysts, 1 or 2 percent; common hornblende, 4 or 5 percent; aegirine-augite, 1 or 2 percent; and magnetite and quartz, about 1 percent each. Apatite and sphene are common but together amount to only about 1 percent.

The fact that the monzonite porphyry commonly is flow banded, and that it formed sheetlike, instead of thick bulbous, instrusions, indicates that it was less viscous than was the diorite porphyry at the time of intrusion.

Inclusions in the monzonite porphyry are fewer and smaller than in the diorite porphyry (p. 349). The inclusions that do occur, however, generally contain many of the same minerals as are in the enclosing monzonite porphyry.

Table 2 gives some chemical analyses (in percent) of monzonite porphyry from the laccolithic mountains on the Colorado Plateau.

\section{PLACER CREEK SHI}

The Placer Creek sill extends for 2 miles along the north side of Placer Creek almost due west from the stock. The sill, about 400 feet thick, lies on the south flank of the laccoliths in Horse Mountain and dips southward into the creek as if to pass beneath the laccolith at Oregon Park. It was intruded into the shale of Pennsylvanian and younger formations that separate those two diorite porphyry laccoliths.

Near its western and distal end the Placer Creek sill is brecciated along zones that range in width from 50 to 1,000 feet and trend north. The origin of these brecciated zones is not clear. They appear to be explosion breccias and may have been caused by breach-
TABLE 2.-Chemical analyses of monzonite porphyry from the laccolithic mountains on the Colorado Plateau

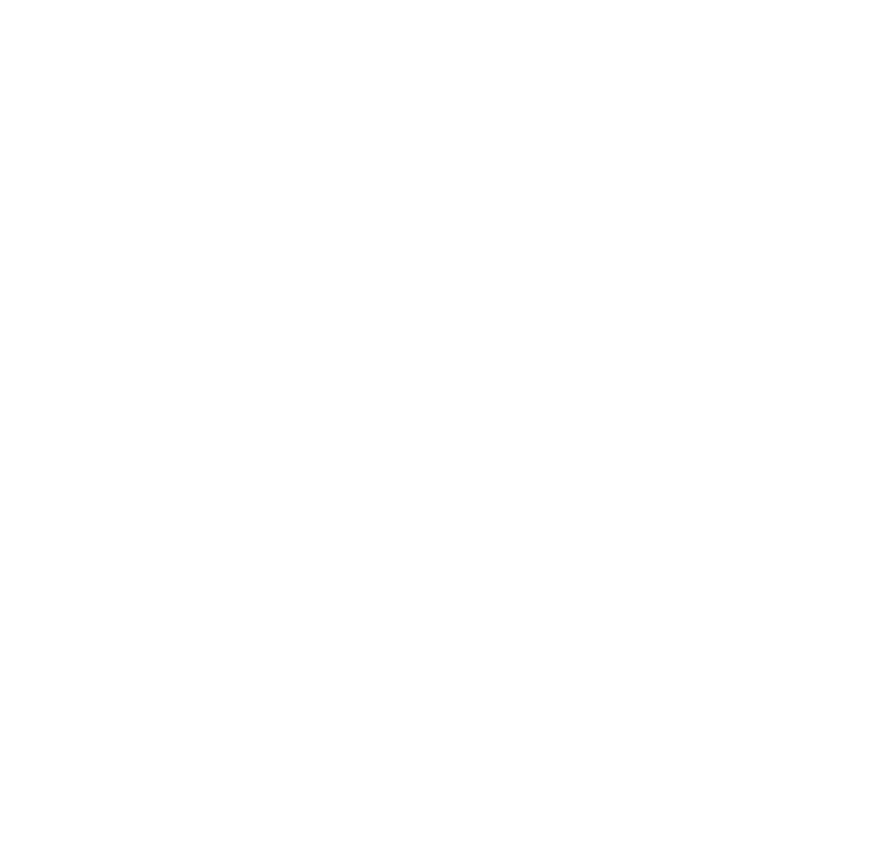

1. Monzonite porphyry, Mount Pennell. Forms sill on divide south of Deer Canyon, SE1/4SW1/4 sec. 4, T. 33 S., R. 10 E. J. J. Fahey, analyst.

2. Monzonite porphyry, Mount' Pennell stock. NE1/4NW1/4 sec. 11, T. $33 \mathrm{~S}$., R. 10 E. J. J. Fahey, analyst.

3. Near Tirbircio Gulch, La Plata Mountains, Colo. H. N. Stokes, analyst. Cross referred to this as syenite, altered(?). Reference: Cross, Spencer, and Purington $(1899, \mathrm{p} .6)$.

ing of the roof at the distal end of the intrusions or by the intrusions coming in contact with ground water in an aquifer or along a fault. In many respects the breccias resemble the explosion breccias in the syenite porphyry in the stock (p. 331) except that they are composed of only the one type of rock-monzonite porphyry, and lack the vesiculation and evidence of oxidation that characterize the explosion breccias in the syenite porphyry. Moreover, it is difficult to understand why explosion breccias should develop at this end of the intrusion instead of at the stock end which is considerably higher.

The breccias may be friction breccias along shear zones that could have formed if salt had moved from under the intrusions. Although the breccias do not resemble the gouge along faults in sedimentary rocks that have been broken as a result of salt flowage, possibly if the salt moved at the time the sill was intruded, the breccia might be attributed to a combination of the two processes.

The volume of the Placer Creek sill is about 0.1 cubic mile.

\section{OTHER DIKES AND SMIS}

South of Manns Peak is a sill of monzonite porphyry. Northwestward, toward the stock, the sill narrows and becomes dikelike and is cut off by the South Beaver vent breccia. 
A sill of monzonite prophyry caps Mount Waas and overlies diorite porphyry. Because the upper part of the sill has been removed by erosion, its original shape and volume are not known; the volume not eroded amounts to about 0.05 cubic mile.

The southwest-trending dike of monzonite porphyry that crosses the summit ridge 750 feet north of Pilot Mountain (pl. 40) is intrusive into diorite porphyry but is cut off by the Panama vent breccia.

\section{NORTH LA SAL STOCK}

By Charles B. Hunt and Aaron C. Waters

\section{GENERAL FEATURES}

The North La Sal stock (pl. 40) is at the geographic center of North Mountain; it includes Mineral and Green Mountains and parts of the adjoining basins. The stock is at the center of the North Mountain dome and no doubt is largely responsible for the doming (p. 316). Radiating from the stock are the laccoliths of diorite porphyry and the laccoliths, dikes, and sills of monzonite porphyry just described. Although the structural relations in North Mountain are not nearly so well exposed as in the Henry Mountains, there is little doubt but that the diorite porphyry and monzonite porphyry intrusions are satellites injected radially from the stock. Moreover, they are bulging intrusions whose long axes radiate from the stock.

Also radially arranged around the stock and breaking the diorite porphyry and monzonite porphyry intrusions are zones of steeply dipping sheeted joints along which there has been hydrothermal alteration. These sheeted zones become more narrow and the joints in them more widely spaced with increasing distance from the stock and the hydrothermal alteration along them diminishes. There seems little doubt that the stock produced these structures and then caused the hydrothermal alteration along them.

The area covered by the stock is about $1 \frac{1}{2}$ square miles. It is elongated somewhat parallel to the long axis of the North Mountain dome and Castle Creek anticline; this length is about $1 \frac{1}{2}$ miles, the width is slightly less than 1 mile. The volume of the stock to a depth equal to the height of the North Mountain dome is about $1 \frac{1}{2}$ cubic miles.

Whereas the satellite intrusions surrounding the stock exhibit little variation in rock type or composition, the stock contains a wide variety of rock types, including diorite porphyry, syenite porphyry, noselite (or sodalite) syenite porphyry, soda syenite porphyry, aegirine granite porphyry, and soda rhyolite porphyry. The oldest of these is a highly altered remnant of the diorite porphyry stock that fed the diorite porphyry laccoliths. No remnant has been found, however, of $448662-58-4$ the monzonite porphyry that at one time must have occupied part of the stock.

The early facies of the stock must have been physically injected and responsible for the doming of North Mountain in the same way as the diorite porphyry and monzonite porphyry stocks produced the domes at the other laccolithic mountains on the Colorado Plateau (Hunt, C. B., 1953, p. 139). The physical injection of the stocks shattered and crushed the walls. The later facies of the stock show evidence of passive intrusion and assimilation or replacement of the earlier facies and shattered wall rock.

At a late stage in the igneous activity the roof above the North La Sal stock was breached. The resulting volcanic explosions developed a half dozen large pipelike masses of breccia in the eastern part of the stock and along some of the sheeted zones east of the stock. With this volcanic activity occurred an abrupt change in the composition of the irruptives. Whereas the earlier intrusions had been deficient in silica and contained more soda than potash, the intrusions associated with the breccias are silica-rich aegirine granite and soda rhyolite porphyries containing more potash than soda.

\section{DIORITE PORPHYRY}

The diorite porphyry stock is in a fragmentary condition because it has been cut and extensively altered by so many later intrusions. Originally it must have occupied most, if not all, of the space represented by the present stock.

Probably this stock began as a small plug, like the stock at Mount Holmes in the Henry Mountains, and progressively enlarged by physical injection until it was a mile or so in diameter. It was the source for the diorite porphyry laccoliths, for these radiate from the stock. The volume of the diorite porphyry laccoliths is about 5 cubic miles; the stock, down to a depth equal to the height of the North Mountain dome, must have included another cubic mile of diorite porphyry. The volume of diorite porphyry intruded at North Mountain is greater than that at the other La Sal Mountains and greater than that in any of the Henry Mountains except Mount Ellen.

Judging by the mineral and chemical similarity between the diorite porphyry in the stocks and laccoliths at the other La Sal Mountains and Henry Mountains, the mineral and chemical composition of the diorite porphyry in the North La Sal stock originally must have been quite like that in the surrounding laccoliths. Moreover, comparison of the composition of the stocks in the other mountains suggests that the North La Sal stock changed gradually in composition while the 6 cubic miles of diorite porphyry was being irrupted. Comparison of the stocks at Mounts Holmes, Ells- 
worth, Hillers, and Ellen suggests that the silica remained about constant; that soda and potash increased about 1 percent each; that lime decreased about 1 percent.

The stock no doubt was a composite of many different textural varieties of the diorite porphyry but generally similar to the laccoliths. Locally there may have been masses that cooled more slowly and developed quartz phenocrysts, as at Mount Ellen (Hunt, C. B., 1953).

The remnants of the diorite porphyry stock have been extensively altered. The phenocrysts of oligoclase have been replaced by albite and perthite. The hornblende is completely gone; not even relic hornblende has been recognized in any of the thin sections from the diorite porphyry in the stock. Its place is taken by a new suite of minerals-aegirine-augite, biotite, and hedenbergite or actinolite. These occur as pseudomorphs after hornblende, as isolated crystals, as crystal swarms, or in veins; these mafic crystals range from microlites to a millimeter in length. Pyrite is common. The apatite and sphene seem no different from the apatite and sphene in the unaltered diorite porphyry, but sphene may be somewhat more abundant. The original groundmass has recrystallized and the rock now is granular.

Chemical analyses of the altered diorite porphyry are not yet available, but the mineralogy suggests that the altered porphyry is more sodic and more potassic and perhaps slightly less silicic than the original diorite porphyry.

As the diorite porphyry stock was intruded, it no doubt shattered and hydrothermally altered the sedimentary formations turned up along its walls and probably in the same manner and to about the same degree as around the stocks at the other laccolithic mountains. The early effects, however, have been destroyed, or largely so, by the deformation and extensive alteration that accompanied the later intrusions in the stock.

Remnants of the original shatter zone are preserved around the south, west, and north sides of the stock. These include some rocks that are from the Precambrian, but they have been greatly altered and now include many of the minerals that characterize the later intrusions and in part have been assimilated by them. This alteration is discussed more fully on pages 335 338.

When the diorite porphyry stock was emplaced, hydrothermal alteration probably amounted to no more than a slight leaching of the mafic minerals in the walls adjoining the stock and deposition of epidote and specular hematite within a few hundred feet of it. These effects are completely masked as a result of later alteration but can be inferred from evidence at the other laccolithic mountains.

\section{MONZONITE PORPHYRY}

No remnants of monzonite porphyry have been recognized in the stock, but its former presence is indicated by the monzonite porphyry sills and dikes that radiate from the stock and that are cut off by the later syenite intrusions in it. The former presence of monzonite porphyry also is suggested by its occurrence in the stocks at South Mountain and at Mount Pennell, in the Henry Mountains, at both of which the igenous activity ended with the intrusion of monzonite porphyry. In composition the monzonite porphyry of the stock was no doubt similar to the dikes and sills.

The volume of monzonite porphyry, including the part that must have been in the stock, is substantially less than 1 cubic mile; probably it is less than half a cubic mile. The volume here is greater than that at South Mountain and is about equal to the volume of monzonite porphyry at Mount Pennell. It is roughly 10 percent the volume of diorite porphyry in North Mountain.

The occurrence of the monzonite porphyry in dikes and sills, in contrast to the bulging laccoliths of diorite porphyry and the better development of flow banding in the monzonite porphyry, indicates that the monzonite was less viscous than the diorite porphyry.

In the stock the monzonite porphyry probably occurred in comparatively small and irregular dikes or pipelike bodies that originally cut the diorite porphyry, as it does at South Mountain and Mount Pennell.

Hydrothermal alteration around the Mount Pennell stock is greater than around other stocks in the Henry Mountains composed of diorite porphyry. No doubt it is significant that the monzonite porphyry produced more alteration than did the much greater volume of diorite porphyry. The same probably was true at the North La Sal stock, but this alteration still is slight as compared with that produced by the later syenitic intrusions.

\section{DIKE-SWARM COMPLEX}

The dike-swarm complex occupies about threequarters of a square mile in the eastern part of the stock (pl. 40). Its volume, to a depth equal to the height of the North Mountain dome, assuming vertical sides, is about 0.7 cubic mile.

The dike-swarm complex consists of closely spaced dikes trending about N. $20^{\circ} \mathrm{E}$., which is very nearly at right angles to the long axis of the North Mountain dome. The rocks between the dikes have a pronounced platy structure; this structure and the flow banding in the dikes also trend $\mathrm{N} .20^{\circ} \mathrm{E}$. On the east side of 
Mineral Mountain, along the east edge of the old diorite porphyry stock, the dikes are so closely spaced that they form a screen, about 85 percent of which is dike material. The intrusive process evidently was by physical injection, as during the earlier stages of the stock. Judging by their forms these dikes probably were less viscous than was the monzonite porphyry.

The rocks are mostly syenite porphyries (fig. 110). Some are conspicuously porphyritic with phenocrysts as much as a quarter of an inch across, but many are nonporphyritic. Between the dikes are altered remnants of earlier facies of the stock and in places fragments of wall rock, including a few blocks from the Precambrian basement.

The feldspars in the dike rocks are perthite and albite or sodic oligoclase. The mafic mineral is aegirineaugite with or without a little biotite. Sphene is an abundant accessory mineral; apatite somewhat less so. In contrast to the earlier intrusions these dikes contain no hornblende, nor do they contain amphibolite inclusions.

The following is a chemical analysis (in percent) by Lucille Kehl, U. S. Geological Survey, of a collection of about 100 rock chips collected every 20 feet along the crest of the ridge between Mineral and Green Mountains. Numerous quite different rock types are included in this bulk sample of the dike-swarm complex; probably a considerable part is sheeted metadiorite between syenitic dikes.

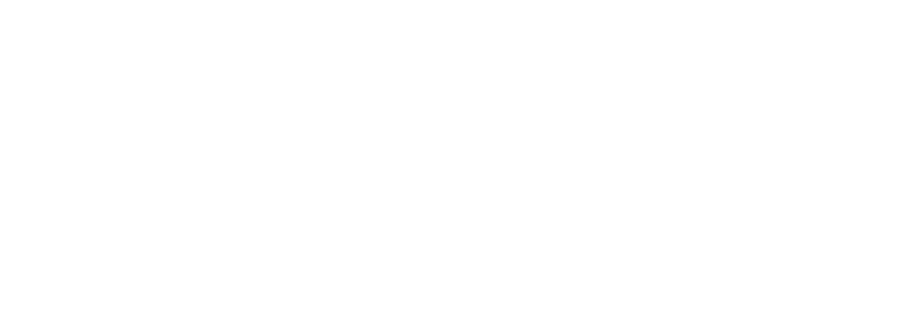

During the diorite and monzonite porphyry stages the North La Sal stock was a massive intrusion that domed the surrounding rocks. Physical injection of the dike-swarm complex probably continued to push the dome upward, but the strong platy structure of the complex trending $\mathrm{N} .20^{\circ} \mathrm{E}$. suggests that the dome became broken transversely across its middle. It seems likely that the linear zones of vertically sheeted joints that radiate from the stock into the zone of laccoliths began developing at this stage. That these radial zones of jointing did not develop earlier is indicated by their absence in the other laccolithic mountains where the intrusive process did not progress beyond the monzonite porphyry stage and by the fact that they break the monzonite porphyry intrusions in North Mountain.

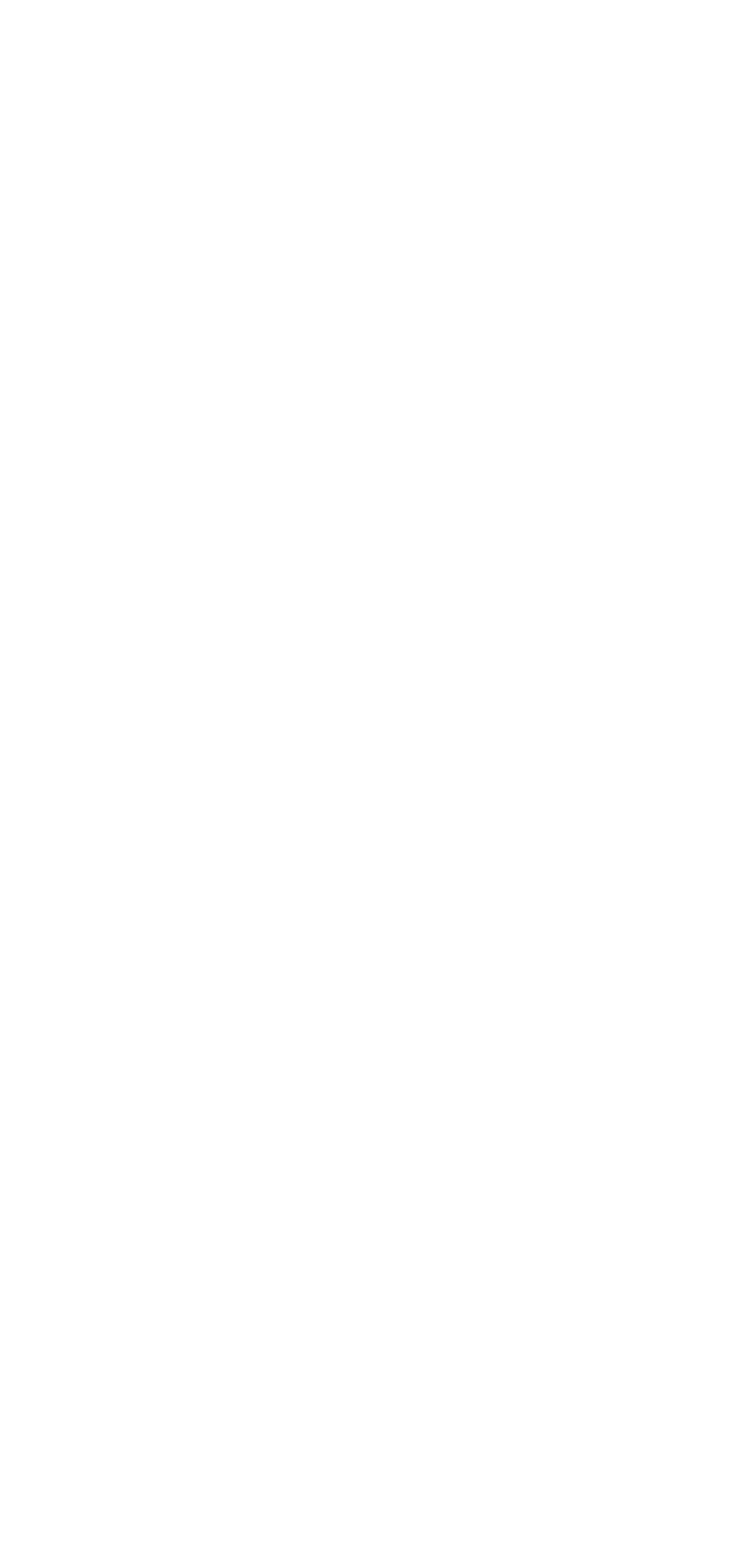

FIGURE 110.-Thin sections of rocks from the dike-swarm complex in the North La Sal stock. Diameter of fields about $2 \mathrm{~mm}$. A. Coarsegrained syenitic dike rock containing quartz (q). The feldspar (f) is mostly perthite. a, aegirine-augite. $B$. Porphyritic, nonquartz-bearing syenite containing sanidine phenocrysts (f). C. Coarse-grained syenite with anhedral perthite (f) and aegirine-augite (a). D. Crossed nicols. Coarse-grained syenitic dike rock (left) does not seem to be chilled against earlier, finer grained and much-altered diorite porphyry. f, sanidine and perthite; a, aegirine-augite; o, argillized oligoclase; and q, quartz.

Intrusion of the dike-swarm complex led to intensive and extensive hydrothermal activity. Perhaps this was because of an increased pressure of volatiles in the syenite as compared with the monzonite and diorite 
porphyry magmas. Or, it may have resulted from increased fracturing that provided more avenues of escape for the volatiles, or both. Whatever the cause, the alteration between the dikes and around the complex as a whole is much greater and more extensive than around the earlier intrusions. Within and adjacent to the dike-swarm complex there is argillic alteration of the feldspars and deposition of calcite and fluorite. In the linear zones of sheeted joints that radiate outward from the stock, the mafic minerals are leached and replaced by pyrite and other sulfides for distances as great as $21 / 2$ miles from the stock. Some of this alteration may have occurred subsequent to the intrusion of the dikeswarm complex, but it must have started at this stage and ended when the explosion breccias were formed. (See p. 330.)

\section{FELDSPATHOIDAL AND OTHER SODA-RICH DIKES}

The feldspathoidal dikes are regarded as part of the dike-swarm complex but representing a late stage of it. The feldspathoidal dikes are much longer and more continuous than are the other dikes. They are continuous through the complex and extend for considerable distances into the surrounding rocks. Some are nearly a mile long, like the one that extends southwestward across McCormick Park and the one that extends north across Bachelor Basin. The abundance of feldspathoidal dikes in and around the dike-swarm complex indicates that they are related to it though somewhat younger.

These dikes commonly are 10 feet wide, but, even if they extend to depths equal to the height of the North Mountain dome, their volume aggregates only about 0.02 cubic mile.

The great extent of these dikes as compared with the earlier intrusions implies either that the viscosity of the magma was continuing to decrease, or that the dome was stiffening and its earlier intrusions congealing, or perhaps both.

The following is a chemical analysis (in percent) by W. F. Hillebrand, of one of the feldspathoidal dikes-a noselite syenite porphyry - north of the stock (Clarke, 1904, p. 191). The specimen was collected by Prindle; the exact location is uncertain, but probably it was collected from one of the dikes north of Bachelor Basin.
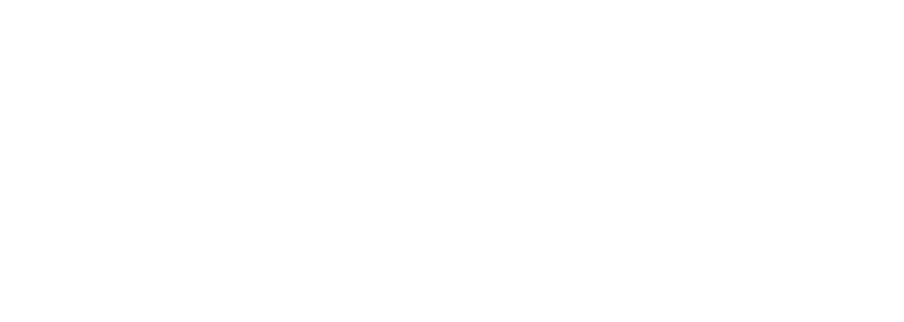

The feldspathoidal dikes are highly porphyritic (fig. 112). Some of them contain rounded phenocrysts of feldspar, mostly perthite, from 1 to 2 inches long. The feldspar in some of the dikes is orthoclase, but generally it is a perthite. The internal texture of many of these perthites suggests that the original feldspar may have been anorthoclase or sanidine that exsolved to a perthite and was later albitized. The cross sections are commonly square or rhomb shaped, and some preserve traces of original zoning.

Sodalite (or noselite) phenocrysts occur in many of the thin sections examined, but more commonly the feldspathoid has been altered to a zeolite and muscovite. Some of these altered areas preserve the crystal outline of the original feldspathoid. In some slides the feldspathoid is contained within phenocrysts of orthoclase

The groundmass commonly is trachytic and consists mostly of potash feldspar and aegirine-augite. Accessory minerals are magnetite, apatite, and sphene.

Hydrothermal alteration along the feldspathoidal dikes has been considerable, perhaps because the continuity of the dikes controlled postdike solutions.

The feldspathoidal intrusion on Brumley Ridge, northwest of Middle Mountain (p. 344) may be related to these dikes. This intrusion is geographically a part of Middle Mountain and is described with the Middle Mountain intrusions. But paragenetically it is wholly out of place among the Middle Mountain intrusions, which otherwise did not evolve beyond the diorite porphyry stage. The intrusion is 2 miles from the Middle Mountain stock and 4 miles from the North Mountain stock. Its isolation outside the zone of laccoliths on either of the mountains is unique. Probably it is related to the feldspathoidal dike stage of the North Mountain activity.

\section{SODA SYENITE PORPHYRY}

The soda syenite porphyry on Mineral Mountain is mostly intrusive into the earlier diorite porphyry stock, but, in the High Ore Basin, it cuts a part of the dikeswarm complex and is therefore younger.

The main body of this porphyry is elongated N. $45^{\circ}$ E. It is about 2,500 feet long and 1,000 feet wide and forms the high part of Mineral Mountain, but long appendages of the porphyry extend down the flanks of the mountain. This curious outcrop pattern makes it difficult to judge the shape of the intrusion. Perhaps it is similar to the dike swarm and consists of vertically continuous sheets. Or, it may be irregularly rooted under Mineral Mountain and grade downward into a very different type of rock. Assuming, however, that it represents a column equal to the height of the North Mountain dome its volume would be about 0.15 cubic mile. 
Protoclastic and filtration effects are conspicuous along the contacts between the soda syenite porphyry and the earlier rocks which it intrudes. Figure 111 illustrates the kind of filter-press phenomenon that is common around the edges of this intrusion. It evidently was intruded as a crystal mush with the large perthitic phenocrysts already well developed.

The following are chemical analyses (in percent) of the soda syenite porphyry. The exact location of specimen 2, is not certain, but it was collected by Prindle 1 mile west of Mount Waas. Prindle described the rock as a nepheline syenite but nepheline has not been found in the thin sections examined by us.

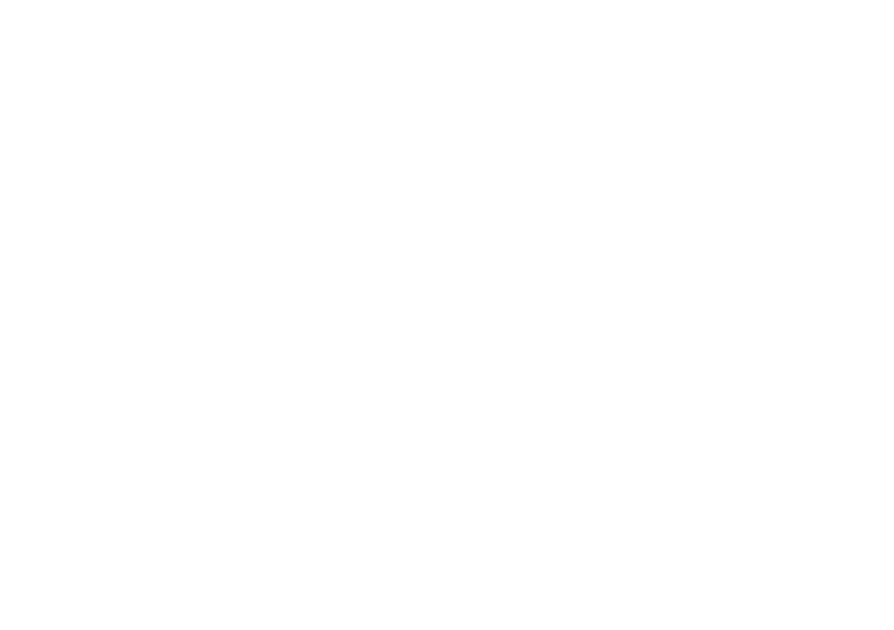

1. Upper part of Snowslide Gulch, Mineral Mountain. W. J. Blake, Jr., analyst. 2. Collected by L. M. Prindle 1 mile west of Mount Waas. Analyzed by W. F. Hillebrand. Prindle referred to this rock as pulaskite, a nepheline syenite porphyry The locality given by him fits for Mineral Mountain and the analysis is almost identical to that of the soda syenite porphyry given in column 1 . No nepheline, however, has been observed in the thin sections examined by us, Reference: Clark

Potash in this rock is about the same as in the feldspathoidal dikes, but the soda is less and the lime is down to 1.5 percent. Silica is about 4 percent greater than in the feldspathoidal dikes.

The soda syenite contains abundant large microperthite phenocrysts (fig. 112). The rims commonly are albitized. Some phenocrysts contain remnants of anorthoclase or soda sanidine, and it is likely that the microperthite is mainly an exsolution product of such feldspars, perhaps further modified by later albitization of crushed edges. Associated with these coarse feldspar phenocrysts are large corroded phenocrysts of sodic augite that are zoned to aegirine-augite on the edges and along shears that cut the crystals. Locally the corroded augite phenocrysts are also partly replaced by a pale yellow-brown biotite.

Throughout the mass, the feldspar and augite phenocrysts are not uniformly distributed, but are clotted together into indefinite patches, lenses, and streaks. Within these clots the phenocrysts make up more than 60 percent of the rock. Areas of such phenocryst con- centration show strong protoclastic effects; the large crystals are sheared, granulated on their edges, and are pervaded by a nonporphyritic matrix that fills shears and spaces between the crystals or injects the crystal mush as indefinitely bordered veinlets. Under the microscope this matrix and vein-filling material is quite different in appearance and composition from the phenocryst-rich parts of the rock. It consists chiefly of very fresh strongly zoned aegirine-augite and zoned anorthoclase partly exsolved to microperthite. Both the feldspar and the pyroxene are much more sodic than the corresponding large phenocrysts. Thus both the field and petrographic characteristics of this mass in-

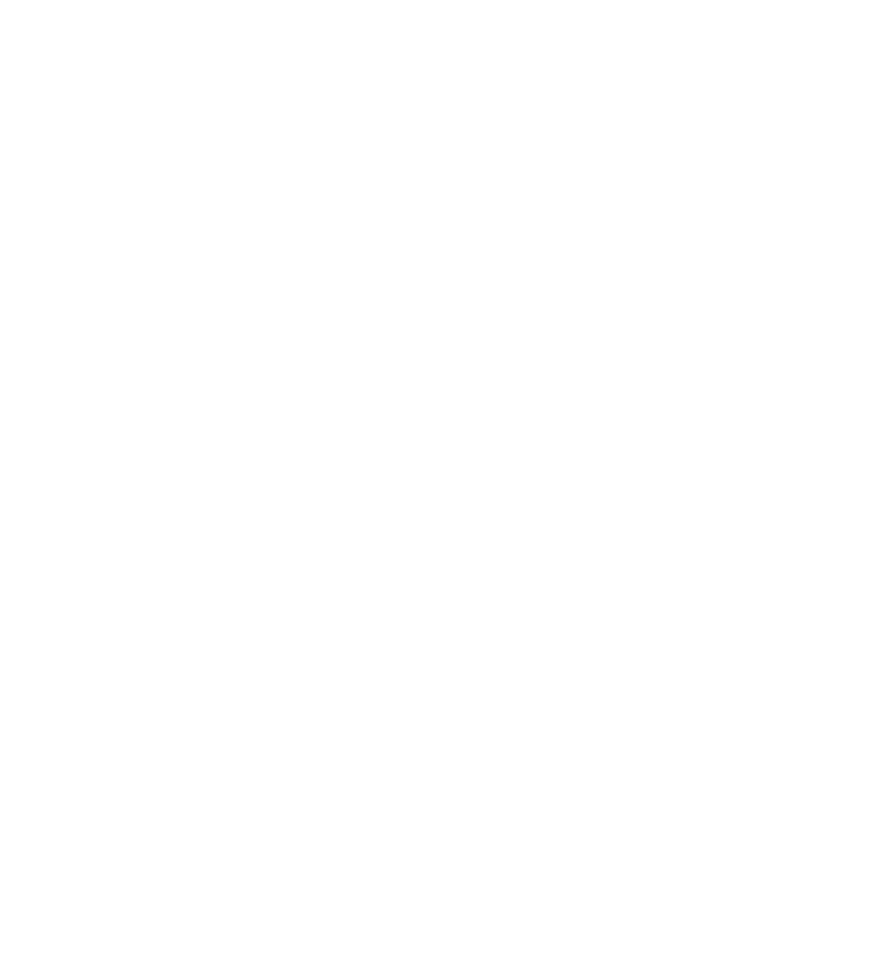

FIGURE 111.-Filter-press relations at contact between soda syenite porphyry and metadiorite in Snowslide Gulch, Mineral Mountain. m, metadiorite; $f$, perthite phenocrysts in soda syenite porphyry; s, paste of soda syenite porphyry.

dicate that the material which flowed into the chamber at present levels was a crystal mush. Forceful injection developed strong mortar and protoclastic structures, which were partly healed by the rest magma that albitized the granulated edges of the feldspars and filled shears with undeformed fresh crystals of aegirineaugite and anorthoclase. This late crystallizing filtrate occurs not only as a filler in and between the older deformed phenocrysts but also as megascopic veinlets and indefinitely bounded dikes in the outcrops.

Evidence of profound gas-phase activity is found around this intrusion of soda syenite porphyry. The diorite porphyry stock is hornfelsized and veined with 
A

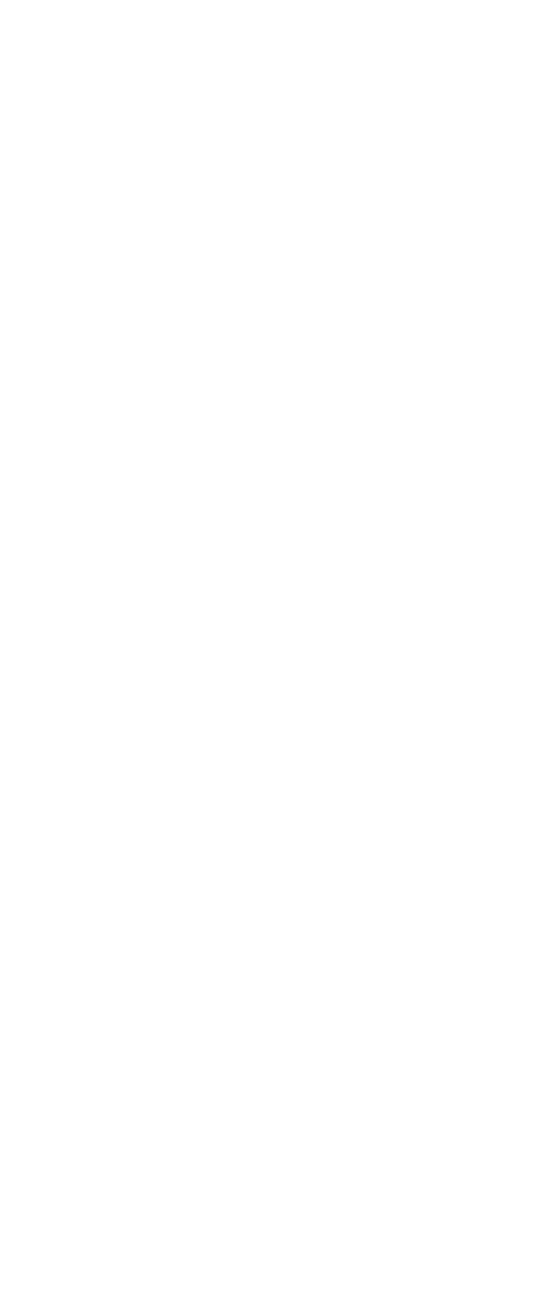

FIGURE 112.-Thin sections of soda syenite porphyry and feldspathoidal dike rocks, North Mountain. Diameter of fields about $2 \mathrm{~mm}$. A. Soda syenite, Mineral Mountain. The porphyry is characterized by huge (as large as 3 inches) phenocrysts of perthite (p) in which the soda and potash feldspars apparently have partly exsolved. $B$. and $C$. Sodalite (noselite?) syenite dikes; $B$. South side, Manns Peak; $C$. South Beaver vent. The sodalite phenocrysts (s) may or may not be encased in the orthoclase phenocrysts (o). The groundmass contains abundant needles of aegirine.

hedenbergite, actinolite, specular hematite, magnetite, pyrite, calcite, and quartz. In the soda syenite porphyry are miarolitic cavities and coarse vugs. The part of the porphyry near the summit of Mineral Mountain is cut by veins of bull quartz and smoky comb quartz.

Several major zones of sheeted joints along which there has been considerable hydrothermal alteration radiate from the stock into the surrounding laccoliths (pl. 39). Similar zones do not occur within the soda syenite porphyry, although it is cut by narrow fissures along which there has been some argillic and pyritic alteration. The soda syenite porphyry must have contributed to the alteration of the zones cutting the laccoliths; the fact that it is not equally altered suggests that there was little additional hydrothermal activity after this intrusion had been emplaced.
In the soda syenite are abundant huge masses-some 100 feet long - of highly altered amphibolite schist, biotite schist, hornblende gneiss, schistose garnetiferous amphibolite, and banded epidote amphibolite. A few small xenoliths appear to have been uralitized pyroxenite and peridotite, but most of them look like typical amphibolites derived from basic lavas or gabbroic rocks. Similar xenoliths, though smaller and fewer, also occur in the metadiorite of the stock (p. 349).

Practically all the large xenoliths show evidence of marked mineral transformations since the episode of dynamic metamorphism that developed their schistosity. In many inclusions the relative proportion of hornblende to plagioclase varies greatly within a few inches. In general, hornblende is more abundant in the margins of the large inclusions than at their centers, although in some the variation in amount of hornblende is completely erratic, and in others it seems to be related to healed fractures and to veinlets that cut the inclusion. Some inclusions are biotitized; small ones may be completely replaced by biotite. The biotite occurs in fine-grained aggregates that commonly replace large original hornblende crystals of the inclusions. Large inclusions are biotitized along their edges, or in some the biotitization follows bands and fractures. The fine-grained aggregates of secondary biotite are distinct from the coarse altered biotite that appears as an original mineral in rare inclusions of biotite schist and hornblende-biotite gneiss. Aegirineaugite also replaces hornblende in some inclusions. There is also evidence that in some inclusions original hornblende, actinolite, and epidote are recrystallized into coarser aggregates rich in secondary hornblende.

These inclusions are most abundant in a zone near the outer edge of the soda syenite, and they occur in the metadiorite as well as in the soda syenite.

Figure 113 is a sketch of one of the partly replaced and syenitized Precambrian schists, most of which $(A$ in fig. 113) is a very fine grained and peculiar biotite. Syenitization of this schist ( $B$ in fig. 113) occurred along transverse fractures and the alteration spread in and along the schistosity. In this syenitized rock, biotite almost disappears except as relics. In the central part of these syenitized zones, microcline and microcline perthite developed. Scattered all through this feldspar are needles, wisps, rosettes, veinlets, and other nondescript masses of an unusual amphibole, possibly actinolite containing a small amount of soda.

Farther out in the biotitized amphibolite is another type of alteration that resulted in the introduction of a peculiar pyroxene that may be a soda-rich diopside. This pyroxene occurs in a zone between the feldspathic, syenitized zone and the biotitized amphibolite, and probably is contemporaneous with the microcline. 


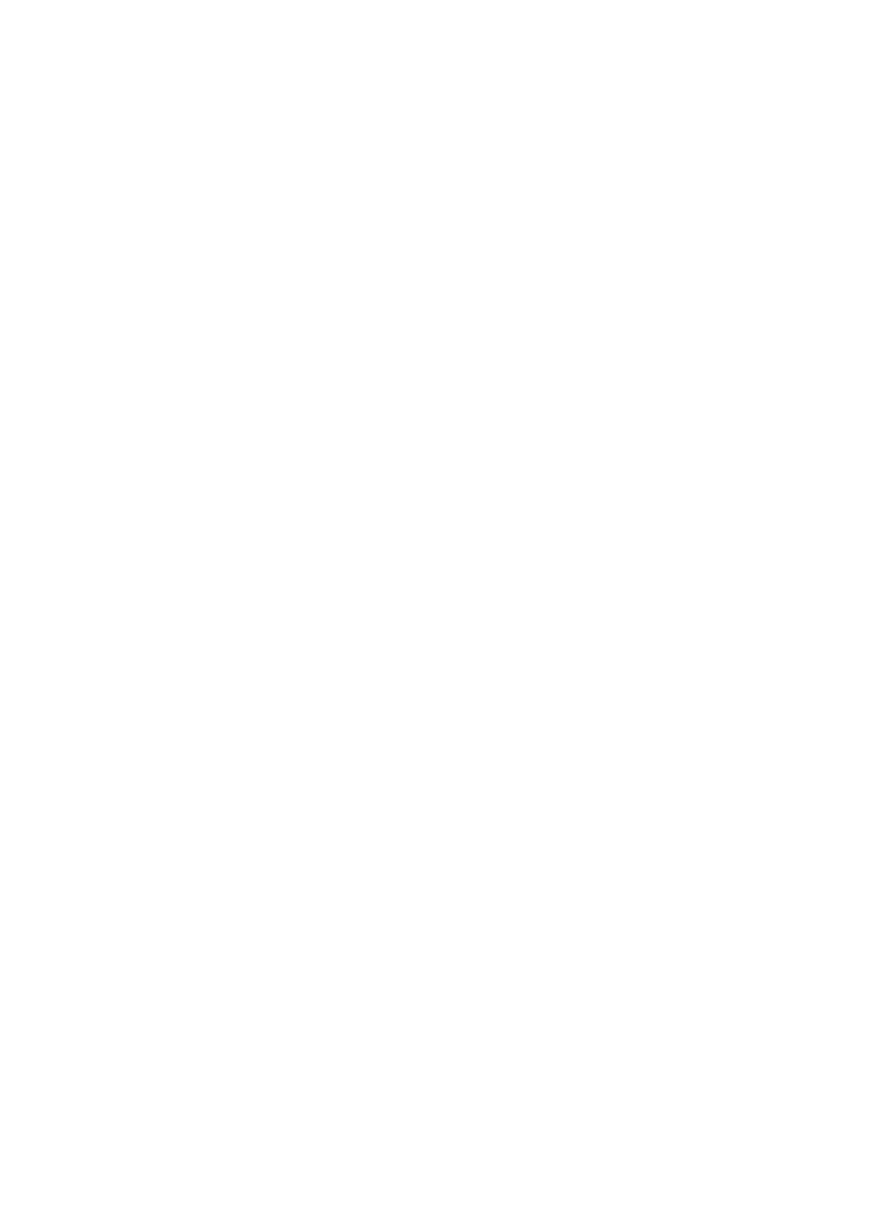

$0 \quad 12$ Inches

Fisure 113.-Sketch of Precambrian schist partly replaced by soda syenite porphyry, at Double Standard shaft, Mineral Mountain. A. Precambrian schist, lines indicate schistosity. $B$. Syenitized schist containing relict structures parallel to the schistosity. C. Soda syenite porphyry. $r$. Veins, mostly hedenbergite. The long veins are 1 to $25 \mathrm{~mm}$ wide; the transverse connecting veins are $1 \mathrm{~mm}$ wide.

Finally, through the middle of the syenitized zone and extending into the soda syenite porphyry are veins of hedenbergite. These branch and become thinner away from the fragment of Precambrian rock and none extends more than a few feet into the syenite. The field relations suggest that the hedenbergite veins are composed of materials driven off from the Precambrian block, but not until after the soda syenite had solidified sufficiently to have fissures. Moreover, the fissures in the Precambrian and in the soda syenite are of the same set, which implies that the syenitization of the schist occurred after the syenite had solidified.

\section{EXPLOSION BRECCIAS AND ASSOCIATED AEGIRINE GRANITE PORPHYRY} AND APHANITIC SHEETS

Explosion breccias, with which are associated intrusions of aegirine granite porphyry and some aphanitic lavalike sheets, formed in the east part of the stock and to the east of the stock after the feldspathoidal dikes were intruded. The breccias cut the hydrothermally altered zones of sheeted joints outside the stock and are younger. It seems almost certain that the breccias and intrusions associated with them are younger than the soda syenite porphyry on Mineral Mountain, although they are not in contact with it. The breccias evidently mark the roots of volcanic vents; the part exposed today must have been many hundreds and perhaps a few thousands of feet below the surface at which the eruptions took place.

There are four major vent breccias and several minor ones. Some of the breccias are intruded by aegirine granite porphyry and by aphanitic lavalike sheets, but these intrusives are themselves brecciated and must be in effect contemporaneous with the explosive activity.

The vent at Green Mountain is one of the largest. It is 1,800 feet long and 1,200 feet wide; the elongation is northwestward. The breccia consists of angular fragments of various types of syenite porphyry, most of them apparently derived from the dike-swarm complex. The fragments are mostly less than 6 inches across and are closely packed. Filling the voids between them is altered comminuted rock. Locally the voids are filled with calcite.

Vugs are numerous and are lined with comb quartz (fig. 114) or calcite. The adjoining breccia locally is mottled with bright red iron oxide, and in places is cut by narrow veins of chalcopyrite and pyrite.

Intrusive into the breccia are sheets of aphanitic lavalike rocks that are involved in the brecciation too. Most of these sheets are only a few feet thick, but one that may be 100 feet thick is exposed near the north side of the vent.

The breccia is banded and the bands dip outward towards the side walls. At the sides these bands are vertical and parallel to the walls, but inward the dip diminishes to $30^{\circ}$ or less. The aphanitic sheets are parallel to the banding and they outcrop concentrically in the vent (pl. 42). In general the breccias grade outward into the nonbrecciated country rock, but locally there is a sharp contact at the edges of the vents (pl. $42 A$ ).

The Green Mountain vent cuts the dike-swarm complex and at least one of the feldspathoidal dikes.

Equally large is the Panama vent (pl. 43), named for the Panama claims, and located 2,000 feet southeast of Pilot Mountain. The breccia in this vent resembles that at Green Mountain but contains considerable quantities of altered diorite porphyry. Intrusive into this breccia, but involved also in the brecciation, is aegirine granite porphyry. This intrusion parallels the banding in the breccia and outcrops as a ring 


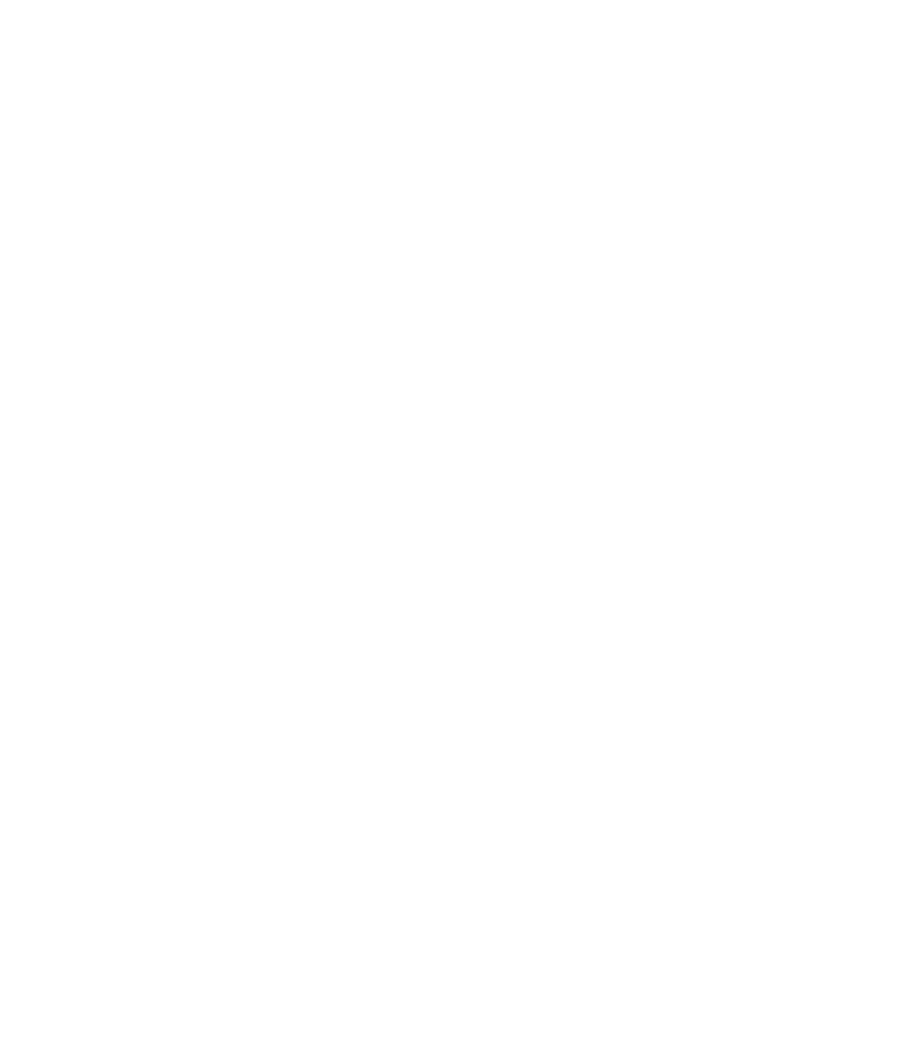

Figure 114.-Vesiculated syenite porphyry from vent breccia on Green Mountain. The vesicles are lined with comb quartz over bull quartz (heavy black). Each vesicle is bordered by a zone in which the porphyry is stained red with hematite; these red zones grade outward to yellow or gray porphyry.

dike in the east part of the vent. The banding of the breccia dips outward towards the walls as it does at the Green Mountain vent. The Panama vent breccia is mostly in diorite porphyry, but it cuts the monzonite porphyry dike that trends southeastward across the north part of Pilot Mountain.

The West Beaver vent (pl. 43), located 1,500 feet northeast of Pilot Mountain, is only about 500 feet long and 300 feet wide, but it is unique in being at the center of an intrusion of aegirine granite porphyry. The intrusion is 1,000 feet long and 600 feet wide; both the intrusion and the vent breccia at its center are elongated to the northwest. The breccia includes considerable quantities of the aegirine granite porphyry. The intrusion cuts a hydrothermally altered zone of sheeted joints in diorite porphyry.

The South Beaver vent, located 3,500 feet southeast of Pilot Mountain, is about 1,200 feet long and 600 feet wide. It cuts a hydrothermally altered zone of sheeted joints, a feldspathoidal dike, and a monzonite porphyry dike. Along the northeast wall the banding in the breccia is vertical, but inward it flattens to about $30^{\circ}$. Sheets of aphanitic lavalike rock, each a few feet thick, parallel the banding and are themselves broken by the brecciation. Three dikes of soda rhyolite cut the vent breccia.

Other similar vent breccias are located at the head of McCormick Park at the south foot of Green Mountain, in Bachelor Basin at the north foot of Green Mountain, and on the summit ridge between Green and Pilot Mountains.

The chemical composition of the aegirine granite porphyry associated with these vent breccias is illustrated by the following analyses (in percent).

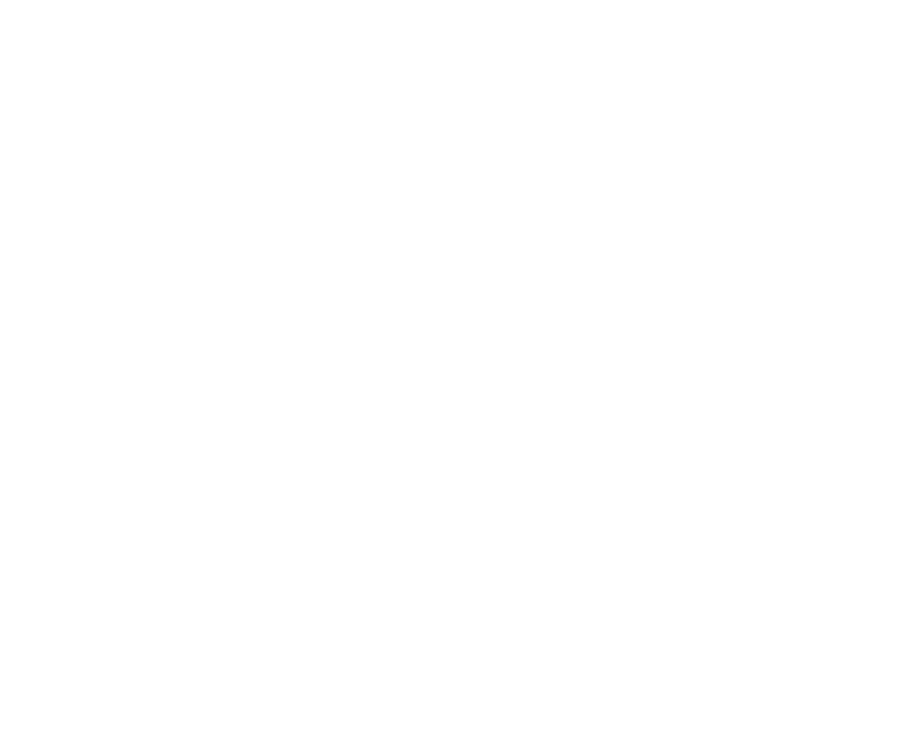

1. Aegirine granite porphyry from Beaver Basin, probably from the West Beaver vent or from the Panama vent. L. M. Prindle, collector; W. F. Hillebrand, analyst. veference: Clarke (1904, p. 191). M. Prinde, collector; W. F. Hillebrand, analyst. 2. Dike, north spur Green Mountain. Probably related to the soda granite, but it Geological Survey, analyst.
Geal

The chemical composition of this rock is very different from that of the earlier intrusions. The silica is much greater, potash is greater, and soda is less. Apparently the vulcanism so changed the physicalchemical environment as to cause what appears to be a sharp discontinuity in the magmatic series. This problem is discussed more fully on pages $353-354$.

Petrographically the aegirine granite porphyry consists mostly of dusty orthoclase (fig. 115). Sodic oligoclase or albite forms the cores in some of the orthoclase crystals and is partly replaced by the orthoclase. Quartz occurs in large euhedral crystals that are much fractured and concentrically lined with tiny needles (rutile?). Quartz also occurs in interstitial masses and in tiny veinlets. A few percent of the rock is aegirine-augite.

Specimens of the large euhedral quartz crystals were separated from the rock and submitted to J. R. Houston, in the geochemistry and petrology laboratory of the Geological Survey, who examined them and reported that "The quartz is high quartz (beta quartz), estimated to have formed between $600^{\circ}$ and $900^{\circ} \mathrm{C}$." 


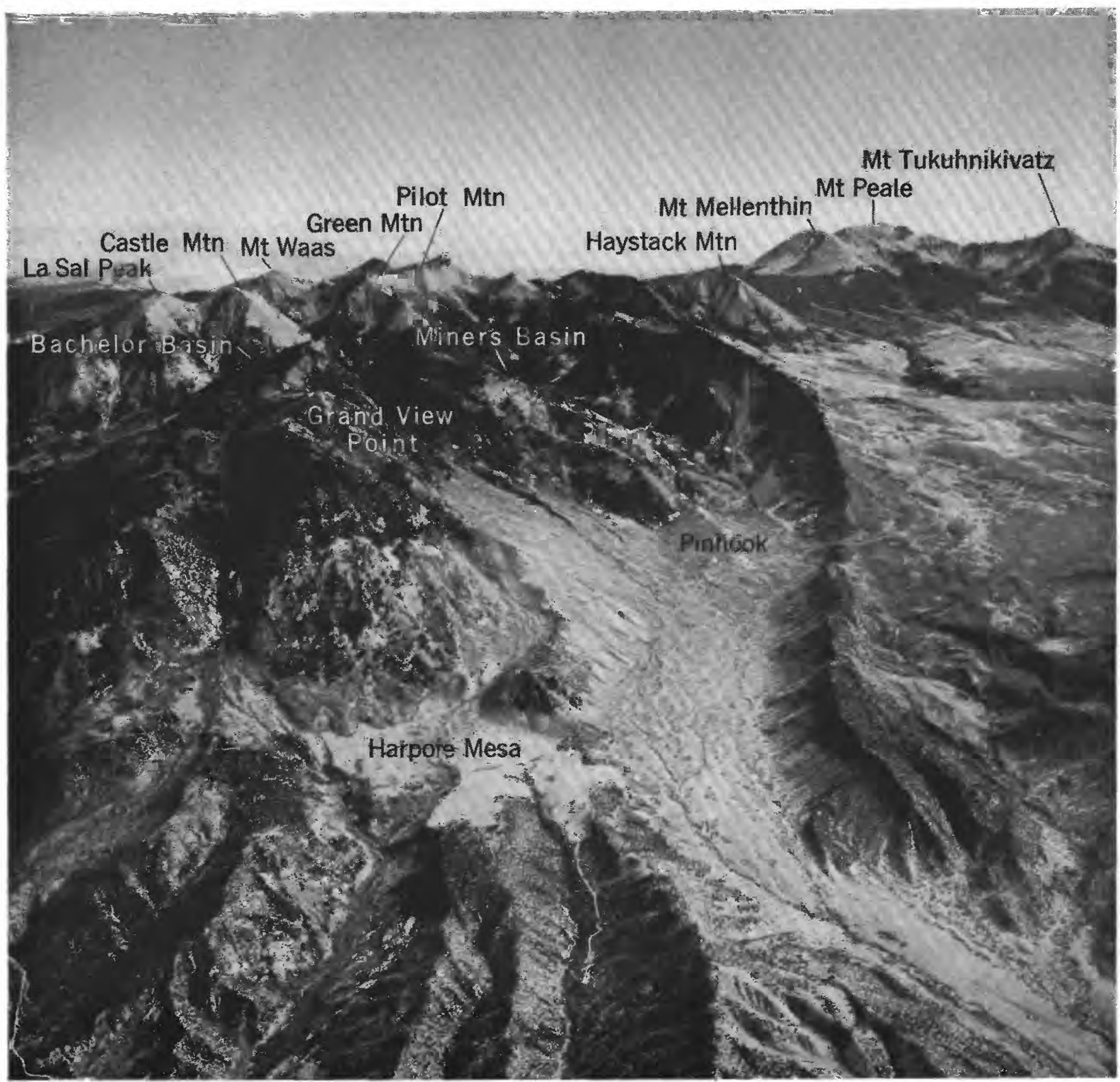

AERIAL VIEW OF NORTH AND MIDDLE MOUNTAINS

View is southeast. Hogback to right of Pinhook is sandstone of Glen Canyon group. The same sandstone dips northeast off Grand View Point, is offset by a fault in Bachelor Basin, and flanks the northeast side of La Sal Peak. Harpole Mesa is underlain by the conglomerate of Pliocene(?) age in Castle Valley. peaks. 


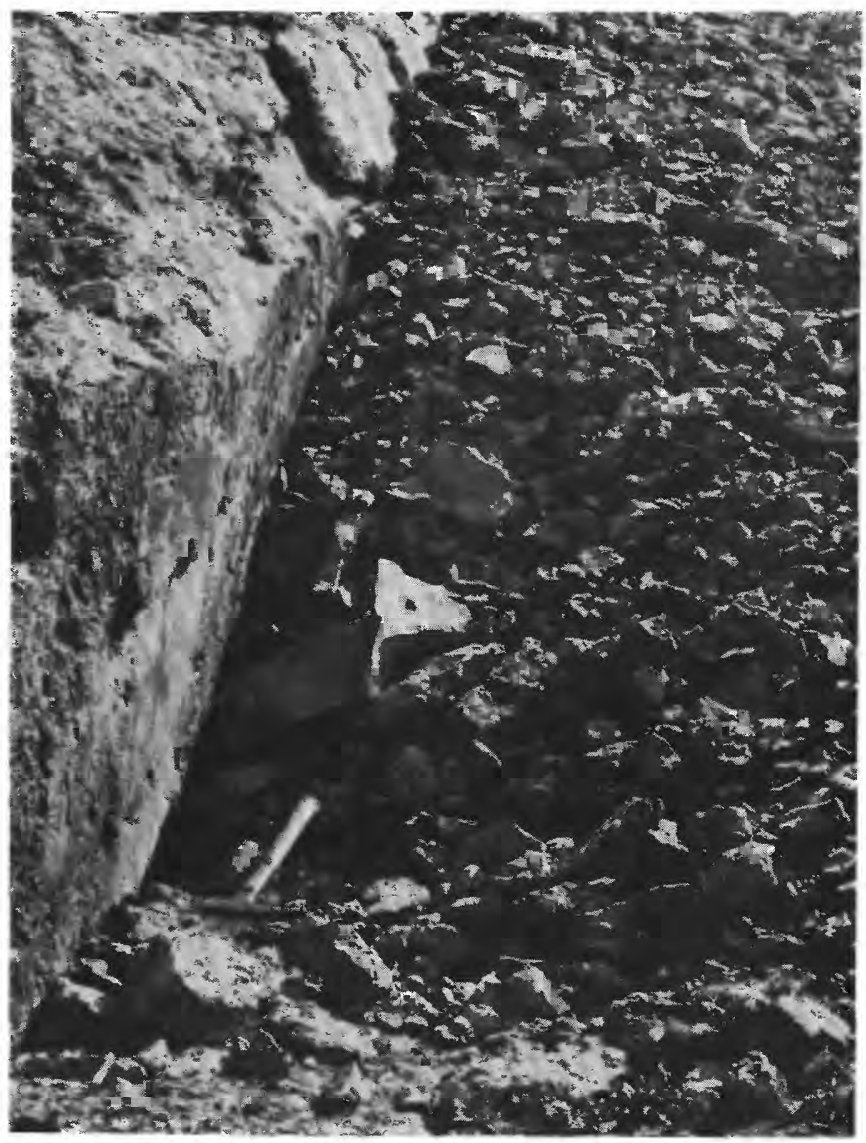

A. Northwest edge. Vertical contact hetween vent breccia (left) and porphyries of the dike-swarm complex.

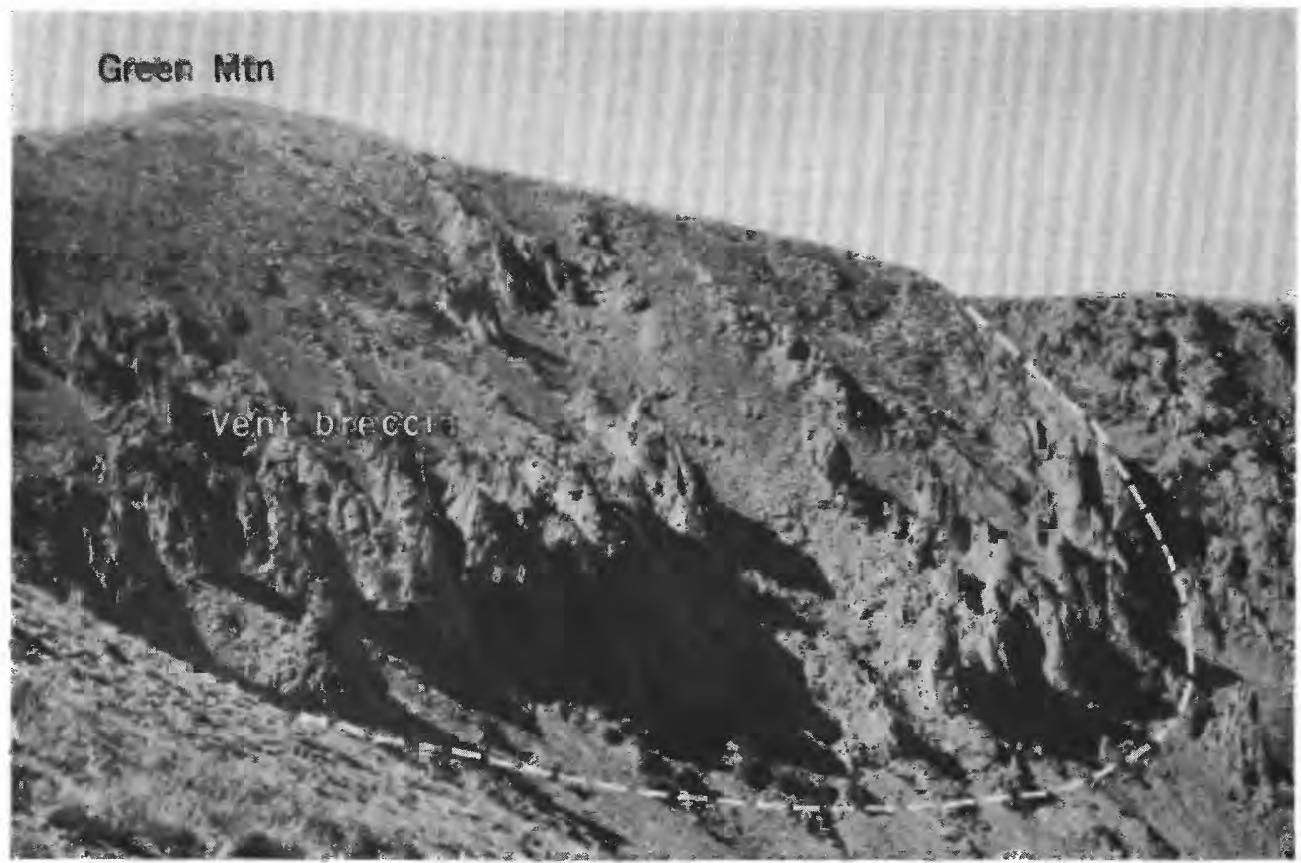

$B$. East side. The crags are breccia containing concentric outward-dipping sheets of aphanitic lavalike rocks. The east edge of the hreccia is at the base of the crags. The northeast edge is on the gully at the right. 


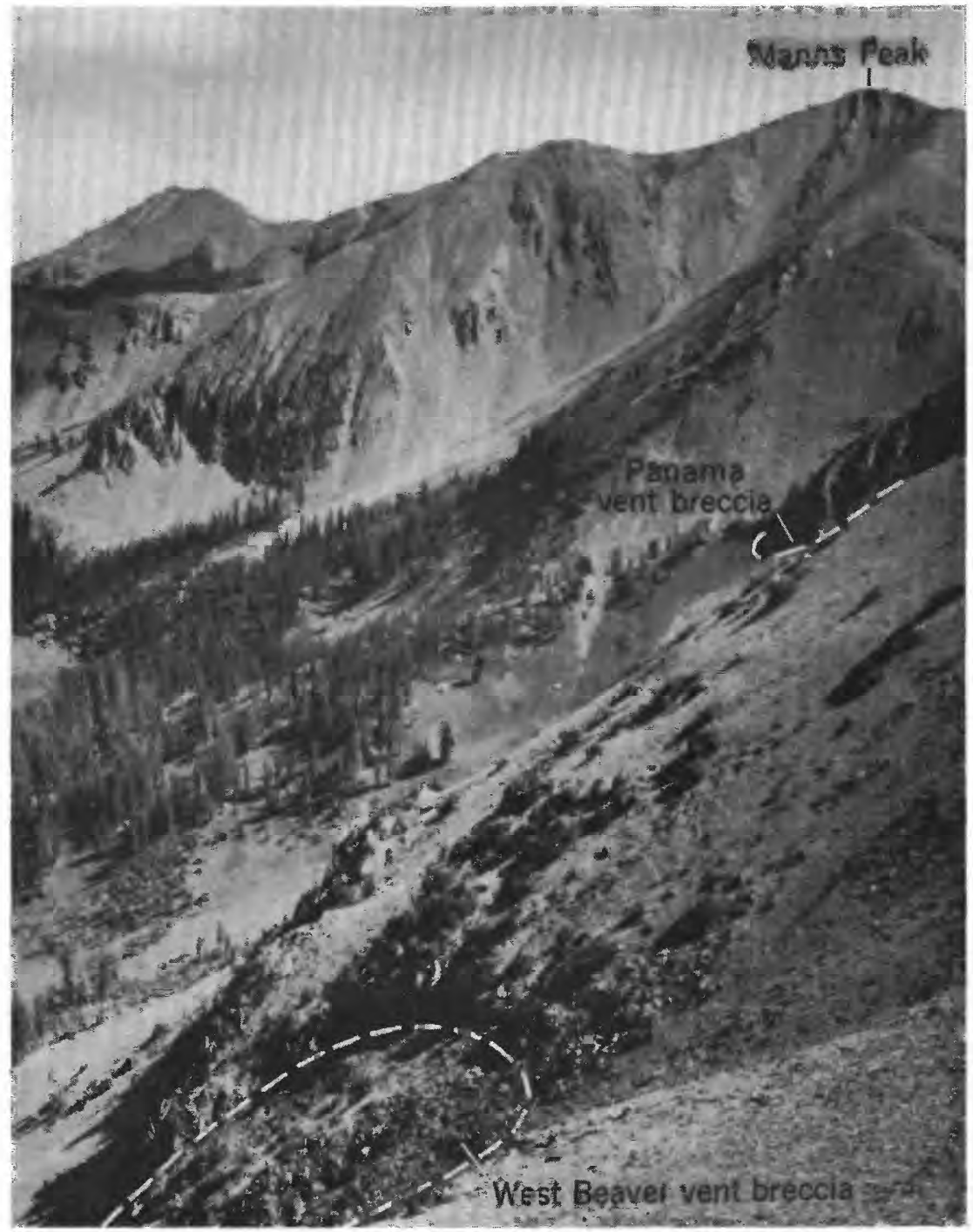

VIEW NORTHWEST ALONG THE VERTICALLY SHEETED JOINTS IN THE SOUTH PART OF BEAYER BASIN 


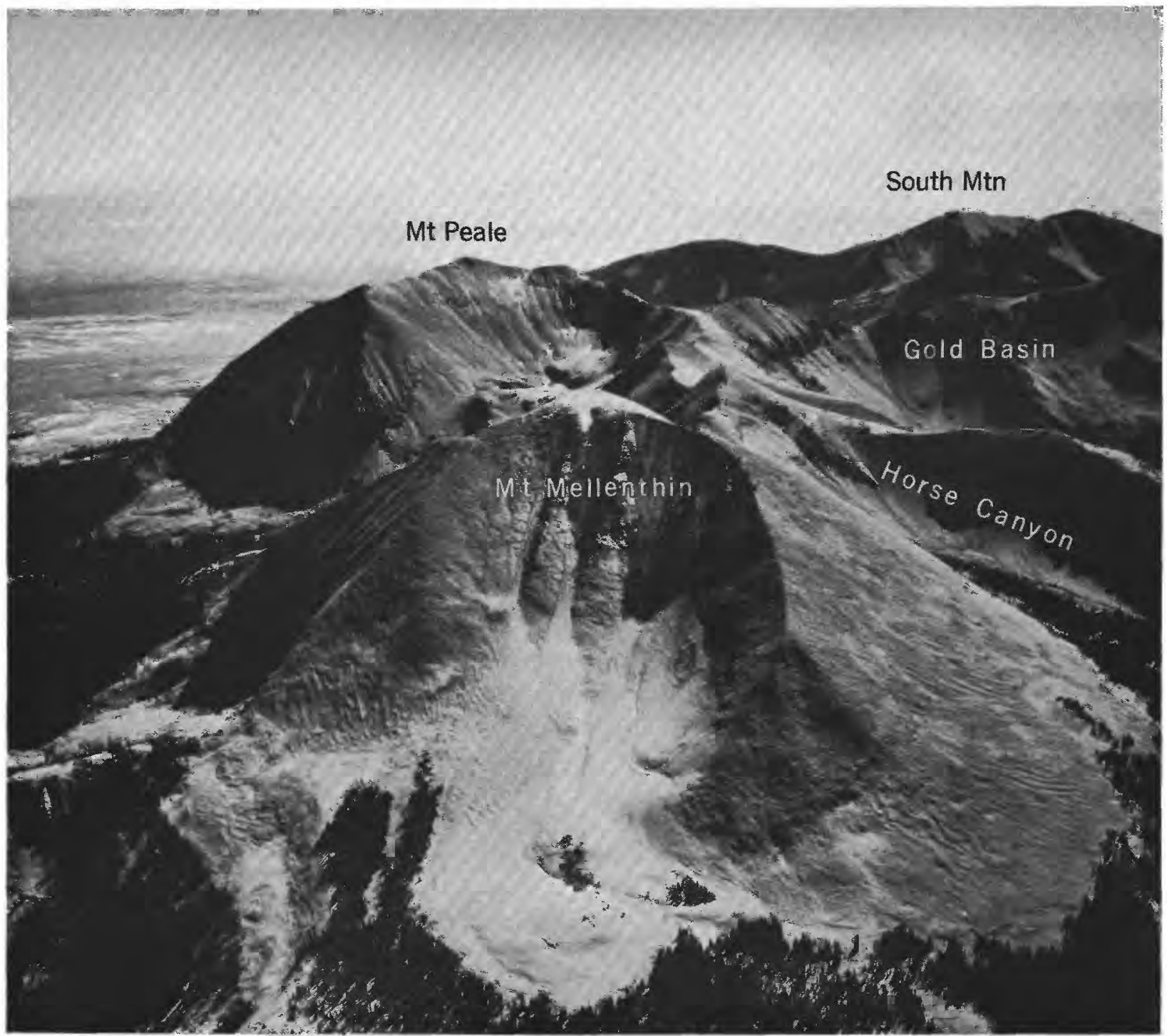

AERIAL VIEW OF MIDDLE MOUNTAIN

The stock is in Gold Basin. Mount Peale is capped with the Morrison formation but is underlain by porphyry in a laccolith injected southeast from the stock. Mount Mellenthin consists of two laccoliths injected northeast from the stock. 


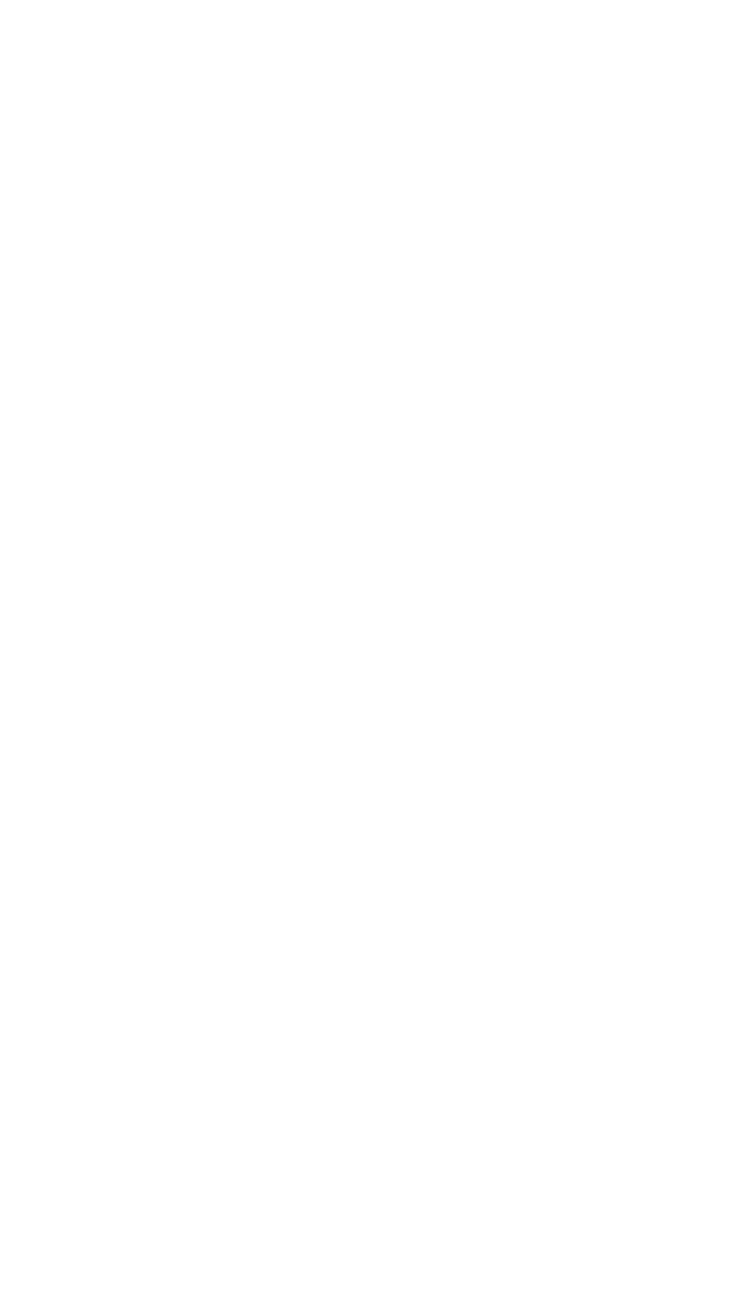

FigURe 115.-Thin sections of soda rhyolite and aegirine granite porphyries. Diameter of fields about $2 \mathrm{~mm}$. A. Soda rhyolite porphyry dike south of McCormick Park. Euhedral quartz (q) is high-temperature quartz. Or, orthoclase; a, aegirine-augite; $a b$, probably originally oligoclase; now mostly orthoclase contain. ing laths of albite. $B$. Aegirine granite porphyry, Panama vent. Letter symbols as in $A$. Groundmass contains abundant aegirineaugite. C. Aegirine granite porphyry, West Beaver vent. Symbols as in $A$. The quartz "phenocryst" may be a porphyroblast, for it has very indistinct edges and seems to have grown outward at the expense of the groundmass.

About 20 percent of the rock in the vent breccias is estimated as new rock, mostly aegirine granite porphyry. Assuming this rock occurs in columnar bodies to a depth equal to the height of the North Mountain dome their volume would aggregate about 0.1 cubic mile.

\section{SODA RHYOLITE PORPHYRY DIRES}

The last phase of the igneous activity on North Mountain is represented by the intrusion of a series of soda rhyolite porphyry dikes. These cut the vent breccias. Unlike the dike-swarm complex almost all the soda rhyolite dikes trend southeastward parallel to the long axis of the North Mountain dome.

All the dikes are less than 5 feet wide but they are long. One near Manns Peak is 1 mile long. It is offset by some minor faults northwest of Manns Peak but cuts all the earlier rocks.

Petrographically these rocks resemble the aegirine granite porphyry (fig. 115). Half the phenocrysts are sodic oligoclase or albite rimmed with perthite that in part at least has replaced the plagioclase. Other crystals are wholly perthite. There is about 5 percent of quartz as phenocrysts but quartz is more abundant in the groundmass. Aegirine-augite occurs sparsely as phenocrysts but abundantly in the groundmass.

The quartz phenocrysts in these rocks are like those in the aegirine granite porphyry. They are euhedral, much fractured, and are lined concentrically with tiny needles (rutile?). Presumably they also are the hightemperature form of quartz.

The groundmass of the soda rhyolite porphyry appears megascopically much finer than that of the aegirine granite porphyry, but microscopically they are not very different.

The volume of these dikes probably equals that of the feldspathoidal dikes, about 0.02 cubic mile.

The table below gives the chemical analyses (in percent) of three soda rhyolite porphyry dikes in the North La Sal stock.

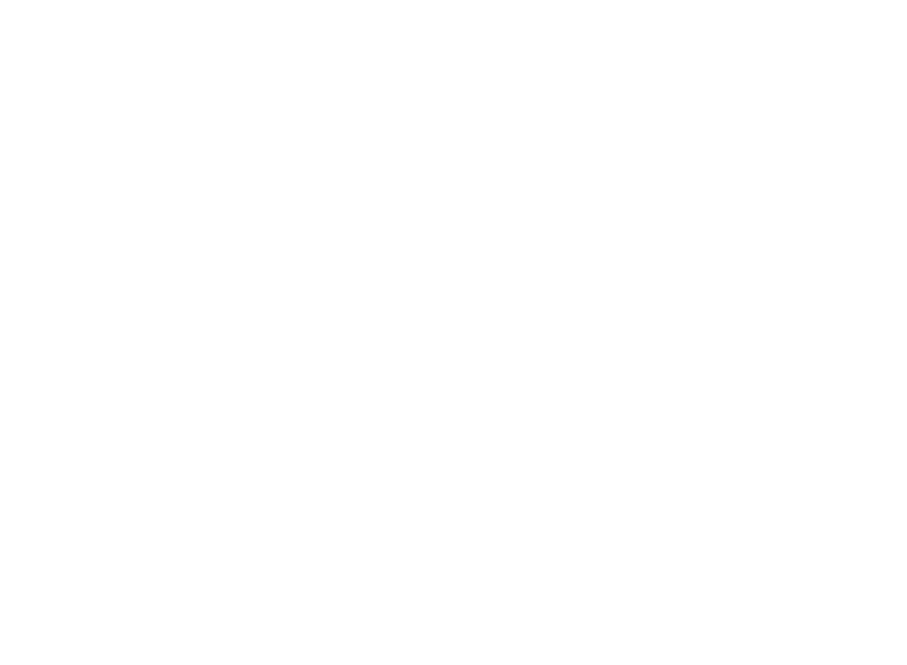

1. Collected by Prindle in Beaver Basin and referred to as syenite aplite. W. F. Hillebrand, analyst. Reference: Clarke (1904, p. 191)

2. Collected by Prindle 1 mile northwest of Mount Waas and referred to by him as syenite porphyry. W. F. Hillebrand, analyst. Reference: idem.

3. Dike $500 \mathrm{ft}$ northeast of Manns Peak. Lucille Kehl, U. S. Geological Survey, analyst.

\section{SUMMARY OF THE STROCTURAL HISTORY OF THE NORTH LA SAI STOCK}

The history of the North La Sal stock begins with the physical injection of a stock of diorite porphyry. At first this stock arched the formations above it (Navajo Mountain stage), but, as it continued to rise, it domed the formations higher and breached them (Mount Holmes stage). When the stock had a diameter of about half a mile, the North Mountain dome probably was about 4,000 feet high. The country rock adjacent to 
the diorite porphyry was shattered and irregular dikes and sills extended outward from the stock into the surrounding domed formations, but as yet there were no laccoliths (Mount Ellsworth stage).

Continued injection of diorite porphyry enlarged the stock to a diameter of about a mile, raised the dome to a height of about 6,000 feet, and gave rise to large bulbous laccoliths that spread first northwestward and southeastward from the stock. The later laccoliths that were intruded northeastward and southwestward from the stock were shorter, for they were transverse to the long axis of the dome. These early laccoliths spread in the Paradox member of the Hermosa formation, but, when that horizon was fully clogged with intrusions of diorite porphyry, the later laccoliths spread in the Morrison formation and Mancos shale. This continued until about 5.5 cubic miles of diorite porphyry had been intruded.

The intrusion of the diorite porphyry into the Paradox member of the Hermosa formation seems to have caused the salt to flow northwestward from in front of and beneath the intrusions.

The next stage in the history of the stock was the physical injection of monzonite porphyry (South Mountain and Mount Pennell stage). It formed dikes and sills in the zone of the earlier diorite porphyry laccoliths and probably formed irregular dikelike or pipelike masses within the stock. During intrusion of the monzonite porphyry there seems to have been a partial collapse at the northwest end of the dome, perhaps because of salt flowing out from under the earlier formed laccoliths. The monzonite porphyry in that part of the area contains breccias suggestive of explosion breccias. The monzonite porphyry was less viscous than the diorite porphyry and spread in narrower intrusions. The volume of monzonite porphyry, however, is small compared with that of the diorite porphyry and aggregates less than half a cubic mile.

After the monzonite porphyry stage, continued upward shove of the intrusions developed transverse northeast-trending fractures across the center of the dome and developed radial zones of sheeted joints in the laccoliths around the stock. The dike-swarm complex intruded the northeast-trending fractures in the stock. The diameter of the stock probably was widened and the height of the dome raised to perhaps 7,000 feet, when dikes, which aggregate about 0.7 cubic mile, became added to the stock. Intensive and extensive hydrothermal alteration began at this stage.

Next occurred what seems to have been the relatively passive intrusion of the soda syenite porphyry at Mineral Mountain. There is some evidence that the intrusion of the porphyry was accompanied by assimilation or, perhaps, replacement of the older rocks which it in- trudes, but it was in part at least physically injected and developed a set of fractures oriented more northeast than those that controlled the dike-swarm complex. Probably the dome was raised to its full height at this stage. The volume of soda syenite porphyry is about 0.15 cubic mile; its intrusion was accompanied by continued hydrothermal activity.

An abrupt change in type of igneous activity occurred when the dome became breached and explosion breccias developed at volcanic centers in the eastern part of the stock and east of it. Perhaps this volcanic phase resulted from further uplift breaching the overlying rocks, or perhaps erosion at the top of the dome had so thinned the overburden that it no longer could contain the intrusions. The release in pressure was accompanied by vesiculation and by a major change in type of intrusive rock to silica-rich varieties. Apparently no large amounts of lava or pyroclastic materials were extruded because the vent breccias are composed of the same kinds of rocks as lie around them.

Igneous activity on North Mountain ended with the intrusion of several soda rhyolite porphyry dikes. The structural history of the stock ends with displacement along some minor northeast-trending faults.

\section{ROCK ALTERATION ON NORTH MOUNTAIN}

Rock alteration in and around the North Mountain stock ranges from mild deuteric alteration of otherwise well-preserved feldspar phenocrysts to strong pneumatolytic alteration that destroyed all previous minerals and rock structures. These alteration effects in the La Sal Mountains were not studied carefully; and therefore we can do little more than report impressions and suggest problems awaiting further study.

\section{STRUCTURAI CONTROI OF AITERED ZONES}

Contacts between intrusions, especially the edges of dikes, have been the location of minor hydrothermal alteration. This alteration is extensive, though not particularly intensive. The walls of the feldspathoidal dikes were favored, presumably because of their continuity and great length. The altered zones along the dike walls generally are only a few feet wide.

Some intrusions in and near the stock are massive and have fissures that occur singly or in zones only a few feet wide. Nevertheless in some of these intrusions the whole rock is altered, and seemingly without regard to fissures or contacts. Some of this alteration may have occurred while the melt was congealing, but that which follows zones of fracturing must have occurred after crystallization and must be the product of bydrothermal activity.

The most extensive and most intensive alteration is along zones of vertically sheeted joints (pl. 43) that radiate from the stock into the surrounding laccoliths. 
In general these joint zones are along the flanks of the laccoliths; several of the widest and longest ones are shown on plate 39 . These joints may be partly the result of original chilling but are chiefly the result of subsequent structural adjustments to later intrusions that caused shearing along the thin edges of the laccoliths. Porphyry generally is more altered than the adjoining sediments. Alteration may affect the outer few feet or outer few tens of feet of porphyry and may extend the whole length of the intrusion, as it does along the sill of monzonite porphyry on the north side of Placer Creek.

The longest and widest of the zones of vertically sheeted joints and hydrothermal alteration extends southeastward from the stock. In the vicinity of Pilot Mountain it is about a mile wide and includes all of Beaver Basin and most of Pilot Mountain. The fissured rock is mostly diorite prophyry, though it is cut by many small younger intrusions and explosion breccias. Very little of the diorite porphyry in this area escaped alteration.

Southeastward from Pilot Mountain the fissured zone divides into several branches. One of these extends southward across the head of Dry Fork. Increasing amounts of unaltered porphyry occur southward along this branch, but the fissuring and alteration persist to the southern edge of the intrusions. The alteration, however, does not extend into the sedimentary rocks at the outer edge of the intrusion.

Another branch of this southeast zone of fissuring extends through, mostly under, the saddle just northeast of Manns Peak (pl. 43) and into the head of Deep Creek, the location of which evidently was determined by the fissure zone. Half a mile southeast of Manns Peak the zone again branches. One branch turns southward along the southeast side of Mount Tomasaki. The other continues southeastward along the northeast flank of Mount Tomasaki, but it again divides into two branches north of the peak. These branches do not extend to the distal end of the laccoliths southeast of the stock.

Little is known about the zone of fissuring where it extends southeastward across Beaver Basin, because the basin is floored with glacial deposits and has few outcrops. Apparently most of the western part of Beaver Basin is fissured, but southeastward the fissured zone divides into narrow branches separated by wider masses of unaltered diorite porphyry that are not noticeably fissured. At the east end of Beaver Basin the diorite porphyry is cut by two zones of vertically sheeted joints. One of these apparently follows the south flank of the diorite porphyry laccolith under Mount Waas; the other is in the north flank of the laccolith at Mount Tomasaki.
One of the most striking zones of vertically sheeted joints and hydrothermal alteration extends southwestward from Mineral Mountain into Tornado Basin. This fissured zone is 1,000 feet wide, and along it the rocks are extensively altered. The intensity of the shearing and alteration diminish rapidly southwestward in Schuman Canyon.

Another, but less conspicuous zone, extends south along the west side of Dry Fork of Mill Creek. Still another zone, though weakly developed, extends across Oregon Park into the head of Schuman Canyon. Very likely a considerable zone of fissuring extends down Placer Creek and controlled the location of that stream; but the fissured zone, if it exists, is buried under glacial moraine. The same can be said of the valley of Bachelor Basin where it drains northward from the stock.

Two other wide zones of jointing and hydrothermal alteration extend northwestward from the stock.

The zones of sheeted joints in the laccoliths structurally resemble the dike-swarm complex in the stock. The dike swarm, which no doubt formed as a result of fissuring in the east part of the stock, accentuates the platy structure in the host rocks of the complex.

\section{DEGREE OF ALTERATION}

Four different degrees of rock alteration can be distinguished on the basis of how well the original minerals, as viewed by hand lens, are preserved.

1. Slightly altered porphyry: less than 50 percent of the hornblende has been altered; relict hornblende outlines are distinct despite the alteration, remainder of the hornblende is fresh; feldspars are clear except for slight cloudy mottling; the twinning is distinctly visible with hand lens and in reflected light; distinct tiny crystals of unaltered original magnetite are abundant.

2. Moderately altered porphyry: hornblende almost entirely gone but some relict outlines can be seen; feldspars are cloudy; twinning is difficult to see with a hand lens, although it may be distinct microscopically under crossed nicols; magnetite is altered and the rock is much stained with limonite.

3. Severely altered porphyry: original mafic minerals are removed; sulfides or secondary oxides may have been introduced; feldspars in part soft and powdery.

4. Recrystallized porphyries: alteration is so complete that a new suite of minerals makes up a considerable part of the rock.

\section{ALTERATION MINERAIS}

Several different secondary minerals were developed by the alteration: epidote, hematite, pyrite, calcite, quartz, actinolite-hedenbergite, fluorite, clay minerals, sericite, albite, and perthite. 


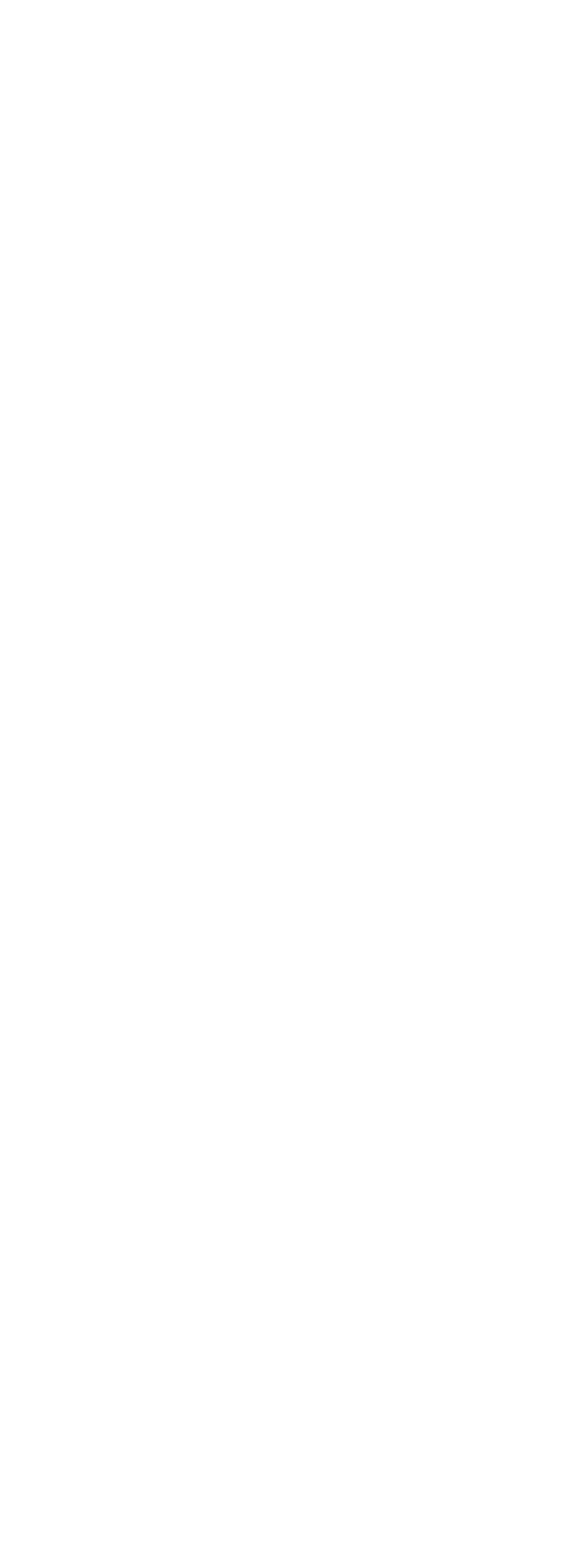

Fioure 116.-Thin sections of altered rocks. Diameter of fields about $2 \mathrm{~mm}$. A. Quartz porphyroblast and quartz veins (q) in diorito
Epidote forms tiny veinlets coating the walls of widely spaced joint cracks in otherwise unaltered diorite porphyry. Epidote is most abundant far from the stock and at the distal ends of the zones of vertically sheeted joints.

Hematite occurs in three ways: as veins of specular hematite, as porphyroblasts, and as disseminated specks coating other minerals or filling the interstices between them.

The specular hematite in veins occurs mostly in the zones of vertically sheeted joints and nearer the stock than does the epidote. Like epidote, it coats the walls of joint cracks between which the diorite porphyry has been altered only slightly.

Cubes of hematite locally are abundant as porphyroblasts in severely altered parts of the diorite or monzonite porphyries. These porphyroblasts probably are of two kinds-in part they seem to be the result of supergene alteration of pyrite and in part they seem to be due to alteration of magnetite that was derived from pyrite. The hematite cubes commonly are abundant and large along joints or other openings; some cubes may be 12 millimeters in diameter. Tiny cubes also occur widely within the altered rock. That these are due to supergene alteration is indicated by the fact that the hematite is mixed with limonite and commonly is restricted to a selvage zone an inch or so wide along the joints; in the interior, the rock contains unaltered sulfides or magnetite.

Hematite also is abundant in the vent breccias where it occurs most commonly in aureoles surrounding the vugs (fig. 114) and in tiny specks finely disseminated through the matrix, coating other minerals, or filling the interstices between them.

Pyrite, locally accompanied by small amounts of chalcopyrite, occurs in veins along fissures and disseminated in the porphyries (fig. 116). Pyritic alteration is extensive in the stock and in the zones of vertically sheeted joints that extend into the laccoliths, but this alteration does not extend so far from the stock as does the specular hematite or epidote.

In the fissures the sulfides generally are scattered irregularly along the open cracks or as narrow stringers a few inches long. They may be associated with calcite, quartz, or occur in the clay gouge. The amount of sulfides in the fissures, though, is small as compared with the amount occurring as porphyroblasts or as small crystals disseminated in the host rocks. Within a couple of hundred feet of the surface much of the pyrite has been replaced by magnetite or limonite.

porphyry. o, oligoclase. B. Calcite nests (black) in diorite porphyry. $o$, oligoclase, with sericitized and a1gillized borders. $h$, relict hornblende. $C$. Pyrite porphyroblasts (p) in diorite porphyry. o, oligoclase. $D$. Argillic selvage (dotted area) in feldspar ( $f$ ) bordering vein of quartz and calcite (qc). 
Calcite is widely distributed and occurs as veins, porphyroblasts, or as an interstitial filling that is finely and widely disseminated in the altered porphyries (fig. 116).

The vein calcite in part occurs as a granular, sugary mass and in part as well-developed inch-size crystals. In some veins, calcite is intergrown with quartz, there being several generations of each. Locally these veins contain minor amounts of sulfides. Calcite veins 2 feet or more wide are not numerous, but they may persist for a thousand feet or more along a fissure. Calcite veins an inch or less wide are abundant.

The disseminated calcite locally occurs as porphyroblasts in the altered porphyry but more commonly occurs as an interstitial filling in the goundmass or as replacement of hornblende or even feldspar.

Although quartz and calcite are found together in some veins, very commonly the calcitic and the silicic alterations seem to have been mutually exclusive. Most of the Mineral Mountain part of the stock, for example, is free of calcite but contains numerous quartz veins. Similar areas of quartz veins that contain little or no calcite are found along the Beaver Basin side of Pilot Mountain and on the southeast slope of that mountain.

Secondary quartz also occurs in veins as porphyroblasts and in nests filling interstices between earlier minerals in the porphyries. (See fig. 116).

The vein quartz is of two kinds and occurs in several generations. Veins of bull quartz several feet wide occur along a few fissures on Mineral Mountain and at one fissure on the ridge southeast of Pilot Mountain. Quartz veins an inch or so wide are numerous south of Manns Peak, on the Beaver Basin side of Pilot Mountain, on the southeast slope of Pilot Mountain, head of McCormick Park, and on Mineral Mountain. More than one generation of veins of bull quartz is indicated at numerous places where one set of veins is displaced by cross fissures that also are filled with bull quartz.

Associated with the bull quartz locally are minor amounts of chrysocolla and chalcedony, the latter very generally being later than the quartz.

The second type of vein consists of comb quartz, in crystals as much as 2 inches long. Some of these are smoky quartz. The comb quartz is younger than the bull quartz and not uncommonly is encased in still later calcite.

Wide veins of bull quartz and comb quartz are lenticular and discontinuous, but networks of anastomosing veinlets form quartzose zones a few hundred feet wide and many hundreds of feet long. Quartz porphyroblasts occur locally in many of the porphyries. Some of these are rounded and embayed, as if being resorbed by a surrounding melt (fig. $109 C$ ). The porphyroblasts in the syenitic porphyries are euhedral bipyramids. They are in part high-temperature quartz (p. 332), they contain abundant rutile(?) needles arranged concentrically, and many of the porphyroblasts are thoroughly shattered (fig. 115). Presumably they represent a temperature condition higher than that which prevailed when the diorite porphyry was injected.

Other quartz occurs in the porphyries in irregular nests of anhedral crystals and in part as an interstitial filling between earlier minerals.

Veins and disseminated crystals of hedenbergite, actinolite, and aegirine-augite are common in the syenitic porphyries. They have already been described (p. 330).

Traces of fluorite occur in several veins in the central and eastern parts of the stock. The fluorite occurs in part as euhedral crystals one-eighth inch across or as a powdery mass interstitial in calcite. It seems to be later than the calcite or quartz with which it is assoeiated, for it coats vugs in the quartz or calcite veins or occurs interstitially in the calcite.

Argillic alteration has occurred locally along the outer edge of the stock, notably at the pass between Miners Basin and Bachelor Basin, at the Dillon adit, and on Grouse Hill. The shape of the clayey masses is not known-they are at least 25 feet wide, but perhaps they are elongated vertically or horizontally along the outer edge of the shatter zone. Perhaps, too, the clay is merely a gouge developed along faults peripheral to the stock.

The oligoclase in the porphyries has been extensively altered to a cloudy cryptocrystalline presumably clayey material (fig. $116 B, D$ ). In general, this argillic alteration of the feldspars occurs near the stock. Farther from the stock, the alteration of feldspars in diorite porphyry most commonly is to sericite (fig. 117).

The plagioclase feldspars are potash bearing, and the potash feldspars contain soda. As a result, in the syenitic series of rocks there is a curious suite of feldspar phenocrysts in the porphyries (fig. $117 B-D$ ).

In the dike-swarm complex some phenocrysts of oligoclase are mottled with perthite that has developed parallel with the albite twins. In the soda syenite porphyry large crystals of soda orthoclase are rounded as if they had been dissolving in a melt, and the interiors of the phenocrysts are irregularly mottled with intergrowths of soda and potash-rich feldspar (fig. $112 A$ ). In the aegirine granite and soda rhyolite porphyries relict oligoclase phenocrysts commonly have a border of orthoclase and an interior of albite laths, orthoclase, and oligoclase (fig. 117). 


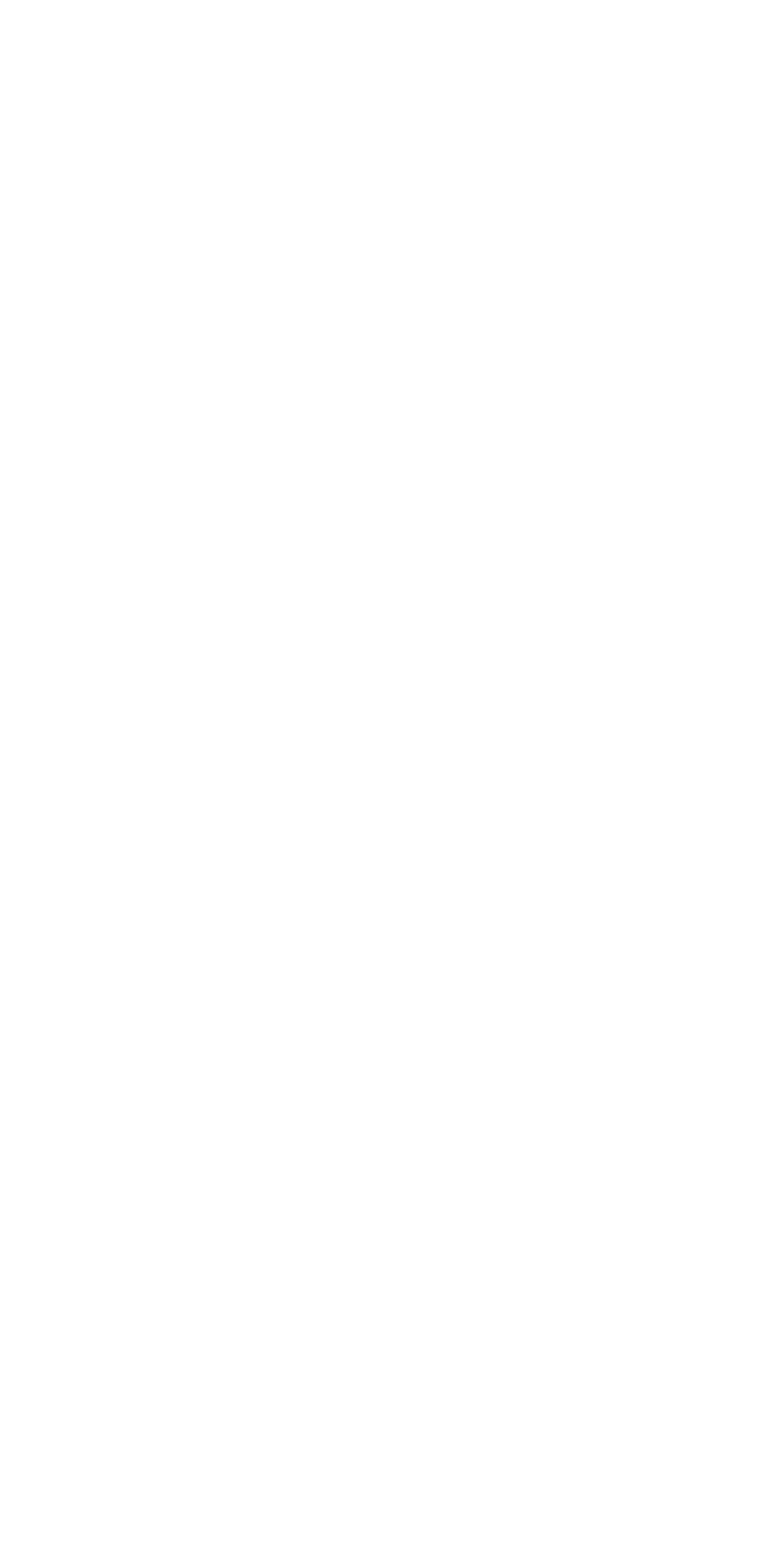

Ficore 117. -Thin sections illustrating alteration of feldspar. Diameter of fields about $2 \mathrm{~mm}$. $A$. Oligoclase (black) replaced by sericite (white), Dorry Canyon laccolith. $R$. Oligoclase (black) mottled by per thite (white), dike-swarm complex. C. Oligoclase (o) replaced by orthoclase (or) at rim and by orthoclase and albite (ab) in interior. Soda rhyolite porphyry dike south of MeCormick Park. D. Similar to $C$, but recrystallization more complete. No oligoclase remains; crystal now is orthoclase (black) and albite (white). Soda rhyolite porphyry dike 750 feet northeast of Manns Peak.

\section{DISTRIBUTION OF METALS}

As an aid in judging the relative importance of the differentiation and alteration sequences in controlling the distribution of different kinds of metals in the La Sal Mountains, several scores of grab samples were collected to determine:
1. Variations in metal content in the unaltered diorite, monzonite, and syenite porphyries.

2. Variations in metal content in various hydrothermally altered facies of each of the principal types of porphyry.

The analyses for copper, lead, and zinc were made by $\mathrm{H}$. E. Crowe, the analyses for selenium by R. F. Dufour and J. W. T. Meadows, and the radiation analyses by S. P. Furman, all in the laboratories of the Geological Survey.

The copper, lead, and zinc content of the rocks increases slightly from diorite to syenite porphyry. Unaltered diorite porphyry contains about $70 \mathrm{ppm}$ (parts per million) of copper, lead, and zinc. Unaltered syenite porphyry averages about $170 \mathrm{ppm}$ of copper, lead, and zinc. The hydrothermally altered porphyries, however, contain, locally, many thousands of parts per million of copper, lead, and zinc.

Selenium also seems to be related to the hydrothermal series and not to the magmatic series, as follows:

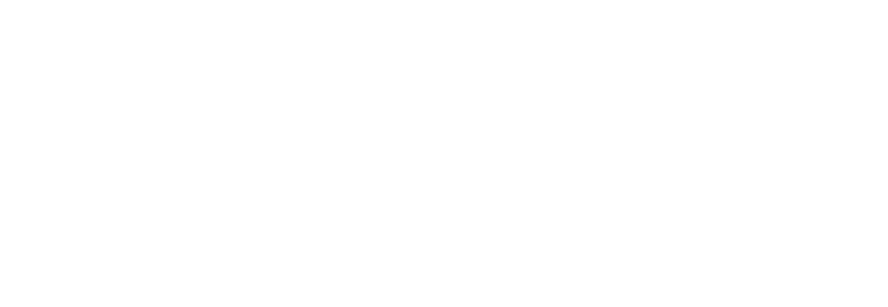

The selenium content of the rocks that have not been hydrothermally altered is about the same whether the rocks are of dioritic, syenitic, or granitic composition. But these unaltered rocks contain only about one-third as much selenium as do the hydrothermally altered ones. The greatest quantities of selenium occur in those hydrothermally altered rocks having the highest content of copper, lead, and zinc.

The samples of hydrothermally altered materials also can be arranged in suites representing five traverses that radiate from the stock. In all five the content of copper, lead, zinc, and selenium decreases away from the stock.

The content of radioactive substances on the other hand appears to show more relation to the magmatic series than to the hydrothermal series.

\begin{tabular}{|c|c|c|c|}
\hline \multicolumn{2}{|c|}{$\begin{array}{l}\text { Number of } \\
\text { samples }\end{array}$} & Rock type & $\begin{array}{c}\text { eU } \\
\text { (average } \\
\text { percent) }\end{array}$ \\
\hline 9 & Syen & 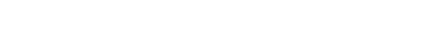 & 0.005 \\
\hline 5 & $\begin{array}{r}\text { Aegi } \\
\text { ve }\end{array}$ & soda rhyolite porphyries and & .004 \\
\hline 25 & Dior & laccoliths_ & .0015 \\
\hline 10 & Met & n & 0016 \\
\hline 14 & Fres & $\mathrm{zs}_{3}$ & .0023 \\
\hline 23 & Hyd & red rocks & .0020 \\
\hline
\end{tabular}

The radioactivity of unaltered rocks averages about the same as the altered ones. On the other hand, the 
radioactivity of the youngest intrusions, which are potash rich, is four times as great as it is in the earlier, less potassic intrusions. Radon has been identified in some of the adits in the soda syenite porphyry (p. 356), and most of these adits in the soda syenite porphyry show radioactivity about three times that of the background. This is especially noticeable in the High Ore adit, where the increase in radioactivity showed only in that part of the workings that extend into the soda syenite porphyry (p. 357).

\section{SOURCE OF THE ALTERATION PRODUCTS}

In only a few mining districts is it possible to answer the question, where did the metal come from? The studies of the intrusions and alteration zones in the La Sal Mountains suggest a partial answer for this area.

The area of calcitic alteration aggregates about 1.5 square miles, is assumed to extend to the base of the laccoliths-at least one-half mile in depth-and to contain an average of 5 percent of calcite. The volume of calcite, therefore, is 0.075 cubic mile, of which, roughly, half is calcium oxide and half is carbon dioxide.

This quantity of calcium oxide could be derived by albitization of 2 cubic miles of porphyry so as to reduce its calcium oxide content from 4 to 2 percent. Much more than this volume of porphyry has been albitized, so there appears to be an adequate local source for the calcium oxide. It must be noted that the calcitic alteration is less extensive than the albitization and the two do not coincide. The calcium oxide, therefore, must have been transported to the areas of calcitic alteration, but the distance it must have moved need be only hundreds of yards.

It should also be noted that, if the calcium oxide were added to the syenitic facies of the stock, the ratio of calcium oxide and alkalies in those rocks would approach that of the diorite porphyry.

The volume of quartz probably is somewhat less than the volume of calcite and may approximate 0.05 cubic mile. This volume of quartz could be obtained from the 2 cubic miles of syenite in the stock by separating $2 \frac{1}{2}$ percent of silica from it, or by separating only half of 1 percent silica from the whole mass of igneous rock including the 7 cubic miles of dioritic magma. Perhaps, however, the quartz is not a direct differentiate but was derived by the hydrothermal leaching that produced the argillic alteration of the feldspars in the porphyries.

The quantity of epidote is small and may have been derived largely from the alteration of hornblende. The total area of the alteration zones in which epidote is the dominant alteration mineral is perhaps half a square mile and it occurs probably to a depth of 2,500 feet. If this half-cubic mile of rock contains 0.01 percent epidote, the total volume of epidote would be 0.00005 cubic mile, or about 250,000 cubic yards.

Hornblende comprises 15 percent of the diorite porphyry; thus about 0.0001 cubic mile of hornblende would have to be altered to provide the calcium oxide and aluminum oxide required for the epidote zone. This volume represents 0.0006 cubic mile of diorite porphyry. But the hornblende is 50 percent removed in at least 2 square miles of the alteration zones; if the average depth of hydrothermal leaching is 2,500 feet, a full cubic mile of diorite porphyry has lost 50 percent of its hornblende-obviously more than enough to provide the materials for the epidote zone.

In the pyritized rocks the hornblende or other mafic mineral has been removed and presumably these mafic minerals were the source for the iron. The amount of sulfide (or iron oxide) in these rocks is about the amount that would be expected if the iron were released from the mafic minerals, for the porphyries that originally contained about 15 percent of hornblende now contain about 5 percent of pyrite. The pyrite, however, is irregularly distributed, parts of the altered zones are in effect without sulfides, iron oxide, or mafic minerals whereas adjoining areas are strongly pyritized. If the iron was derived from the mafic minerals, it probably has not moved far. The sulfur must have been added and must have been brought from greater distances than was the iron.

The pyritized rocks cover at least 2 square miles. As this area includes the stock and immediately adjoining parts of the laccoliths, the pyritization probably averages 1 mile in depth. The total pyrite, therefore, is 0.1 cubic mile, roughly half of this being sulfur and the other half iron. There is adequate local source for this amount of iron and for the iron in the specular hematite and epidote zones too. The quantity of sulfur in the combined form represents about 0.5 percent of the total volume of igneous rock in the mountain but about 2.5 percent of the volume of the stock.

\section{MIDDLE MOUNTAIN}

The intrusions on Middle Mountain (pl. 44) consist of a central stock surrounded by laccoliths that radiate from it. The stock is in Gold Basin, but, unlike the one at North Mountain, it is very poorly exposed and little is known about it.

The Middle Mountain dome differs from that at North Mountain in being almost circular, and the laccoliths within it are equally long in all directions including those transverse to the regional structure. Whereas most of the laccoliths at North Mountain spread in the Paradox member of the Hermosa formation, those in Middle Mountain spread in the Mancos 
shale. Moreover, the fact that the flanks of the Middle Mountain dome are smooth indicates that there are no large laccoliths in the Paradox under that dome.

The intrusions on Middle Mountain are composed wholly of diorite porphyry and aggregate only about 1.6 cubic miles. Three-quarters of this volume is contained in two large laccoliths, one at Mount Tukuhnikivatz and the other at Mount Peale, both intruded in the Morrison formation.

The laccoliths and stock on Middle Mountain are composed of diorite porphyry entirely like that already described on North Mountain. The noselite (sodalite?) syenite porphyry on Brumley Ridge is geographically a part of Middle Mountain but may belong genetically with the feldspathoidal series of North Mountain.

\section{BRUMLEY CREFK LACCOLTTH}

The Brumley Creek laccolith, which occupies the ridge along the south side of Brumley Creek, extends about 11/2 miles northwest from Gold Basin. The crest of the ridge, along which the roof of the laccolith is exposed, is about 750 feet higher than Brumley Creek to the north and about 400 feet higher than Dorry Canyon to the south. The floor of the laccolith is about halfway down the slope to Brumley Creek and probably is at about the same altitude on the Dorry Canyon side. The laccolith is about half a mile wide. Its maximum thickness, about 450 feet, is near the west end of the intrusion, near the $1 / 4$ corner on the south side of sec. 9 T. 27 S., R. 24 E.

This laccolith is in the lower part of the Morrison formation (fig. 118). The floor is almost horizontal but dips slightly west. No exposures of the floor contact were found, but its position can be determined closely in the steep south wall of the valley of Brumley Creek. The roof is exposed in the west part of sec. 15 .

In the first mile northwestward from the stock in Gold Basin the laccolith maintains a fairly uniform thickness of perhaps 300 feet, but the distal and western half mile of the intrusion broke upwards through the roof. Crossing the ridges in the $\mathrm{NE}_{1 / 4}^{1 / 4}$ sec. 16 is an almost vertical contact cutting off the ends of the sandstone beds that form the roof to the east. This discordant bulge has a structural relief of about 150 feet. Its topography probably approximates its original structural form.

In the $\mathrm{NE}^{1} / 4$ sec. 16 the roof of the Brumley Creek laccolith dips south towards the north wall of the Dorry Canyon laccolith. There may be a fault along this part of Dorry Canyon because the two intrusions seem to be at about the same stratigraphic position, but no northward dip off the roof of the Dorry Canyon laccolith was found. The possible fault might also account for the steep north side of the Dorry Canyon laccolith.

Downcutting in Gold Basin has severed the Brumley Creek laccolith from the stock. Presumably the laccolith once extended across most of the north half of sec. 15, and only the thin south edge of the laccolith, in the center of sec. 15 , remains.

The Brumley Creek laccolith is tongue shaped and its axis trends west-northwest from the stock. It thins rather uniformly southward from the axis and may have thinned similarly to the north. Its west end bulged discordantly and lifted the roof by a fault that is on the stock side of the bulge. It is not known whether the west side of the bulge was lifted by folding or by faulting.

The volume of the Brumley Creek laccolith is about 0.03 cubic mile.

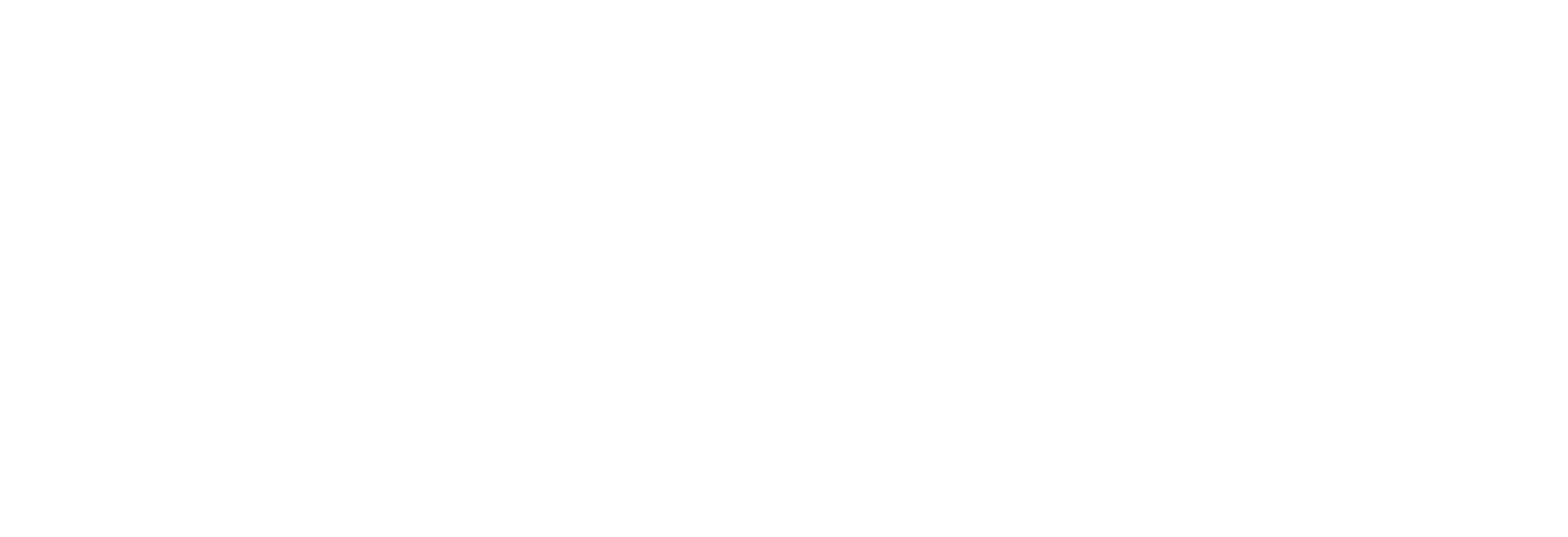

Figure 118.-View west in Gold Basin. The observer is standing in the stock. The view toward Mount Tukuhnikivatz is approximately along the axial bulge of that laccolith. Near the stock, the north (right) wall of the laccolith discordantly cuts across a few hundred feet of strata. The upper ends of two dikes in these strata trend almost west and probably are the feeders for the Dorry Canyon laccolith. In the lower part of the Morrison formation is the south (left) edge of the Brumley Creek laceolith. 


\section{DORRY CANYON LACCOLITH}

The Dorry Canyon laccolith forms the ridge along the south side of the head of Dorry Canyon and extends $1 \frac{1}{2}$ miles west from Gold Basin. It has a maximum width of 1 mile and a maximum thickness of not less than 500 feet.

Exposures on the side towards the stock are good but not complete enough to reveal whether the laccolith continues eastward under the sedimentary formations exposed there or connects with the dikes that cut the sediments. Probably the laccolith was fed by the dikes, and if so its bulging part does not extend much east of sec. 16 .

The laccolith is in the lower part of the Morrison formation except at the easternmost end where it has cut upward into the middle part of the Morrison. The distal end of the laccolith abuts into an area where the host rocks are tilted and faulted, but exposures there are not satisfactory. The mapping in the E $1 / 2$ sec. 17 and adjoining part of sec. 16 may be in error. The distal end of the laccolith forms a cliff 300 feet high and three-quarters of a mile long. The sedimentary formations are exposed only a few hundred feet west from its base.

The Dorry Canyon laccolith ends northward at a steep hillside paralleling the strike of the sandstone beds, which dip $25^{\circ}$ southward off the roof of the Brumley Creek laccolith. This flank of the Dorry Canyon laccolith is as steep at its western and distal end and may be along a fault.

The roof of the laccolith dips about $25^{\circ} \mathrm{S}$., and the intrusion thins southward in a tapering wedge in the north part of sec. 21 .

To the east the main body of the laccolith is separated from the stock by a ridge of sediments that dip about $25^{\circ} \mathrm{S}$. These sediments are cut by several dikes that end both upward and downward in the steep wall overlooking Gold Basin (fig. 118). Lineation in the dikes is horizontal and parallel to the side walls, and the dikes probably are the conduits that fed the Dorry Canyon laccolith. The general form of the Dorry Canyon laccolith, therefore, is like an axe laid on its side, with cutting edge to the south and a slender handle or handles extending east.

The volume of the laccolith is about 0.05 cubic mile.

\section{MOUNT TUKUHNIKIVATZ LACCOLTTH}

The Mount Tukuhnikivatz laccolith extends $1 \frac{1}{2}$ miles southwestward from Gold Basin. The laccolith forms Mount Tukuhnikivatz, the ridge extending northwest from its peak, and the outer slope of the mountain towards Hell Creek. It is 1 mile wide and its maximum thickness is at least 2,000 feet.
The floor of the laccolith is not exposed. It must be lower than Gold Basin at the northeast end and below 10,000 feet on the distal or southwest end. The peak of Mount Tukuhnikivatz is about 13,000 feet; therefore, even assuming a southwest slope for the floor, the laccolith must be at least 2,500 feet thick in its central part.

In Gold Basin, where the walls of the laccolith are well exposed, the side contacts are nearly vertical and cut discordantly upward from the middle part of the Morrison formation to the Dakota sandstone (fig. 118). Where the side wall crosses the summit ridge east of Mount Tukuhnikivatz, the laccolith is in contact with uppermost Morrison or lowermost Upper Cretaceous strata. The contact is almost at right angles to the strike of the beds adjoining it, and the stratigraphic discordance along it is at least 700 feet. The north side of the laccolith roughly parallels the strike of the adjoining formations which, at the contact, dip about $10^{\circ} \mathrm{S}$. But this dip is only half as great as it is 1,000 feet north of the contact and may reflect upward drag.

Along the southwest or distal end of the laccolith, exposures are poor but this edge of the laccolith appears to be concordant at about the contact between the Morrison formation and formations of Late Cretaceous age.

The upper surface of the laccolith, which probably marks the roof at least approximately, plunges about $35^{\circ}$ towards Hell Canyon.

At the northeast base of Mount Tukuhnikivatz the laccolith is sheeted by joints that roughly parallel the side walls but dip less steeply. Upwards the dip of the sheeting diminishes as if the joints were curved across the upper part of the laccolith to meet those rising from the opposite side.

Locally the porphyry is flow banded roughly parallel to the side walls.

The Tukuhnikivtaz laccolith has a volume of about 0.6 cubic mile. Its axis extends southwestward from the stock in Gold Basin, a direction that is transverse to the regional structure. Its large volume, general form, discordant sides and structural setting are quite distinctive from the smaller and more concordant intrusions like the Dorry Canyon and Brumley Creek laccoliths that were injected parallel to the regional structure. The Tukuhnikivatz laccolith may be later than the Dorry Canyon and Brumley Creek laccoliths and was turned southwest by those intrusive masses.

\section{INTRUSIONS AT HEAD OF LA SAL CREGK}

At the head of La Sal Creek and in the southern part of Gold Basin, mostly in sec. 23 T. 27 S., R. 24 E., the Morrison formation is broken by numerous small faults 


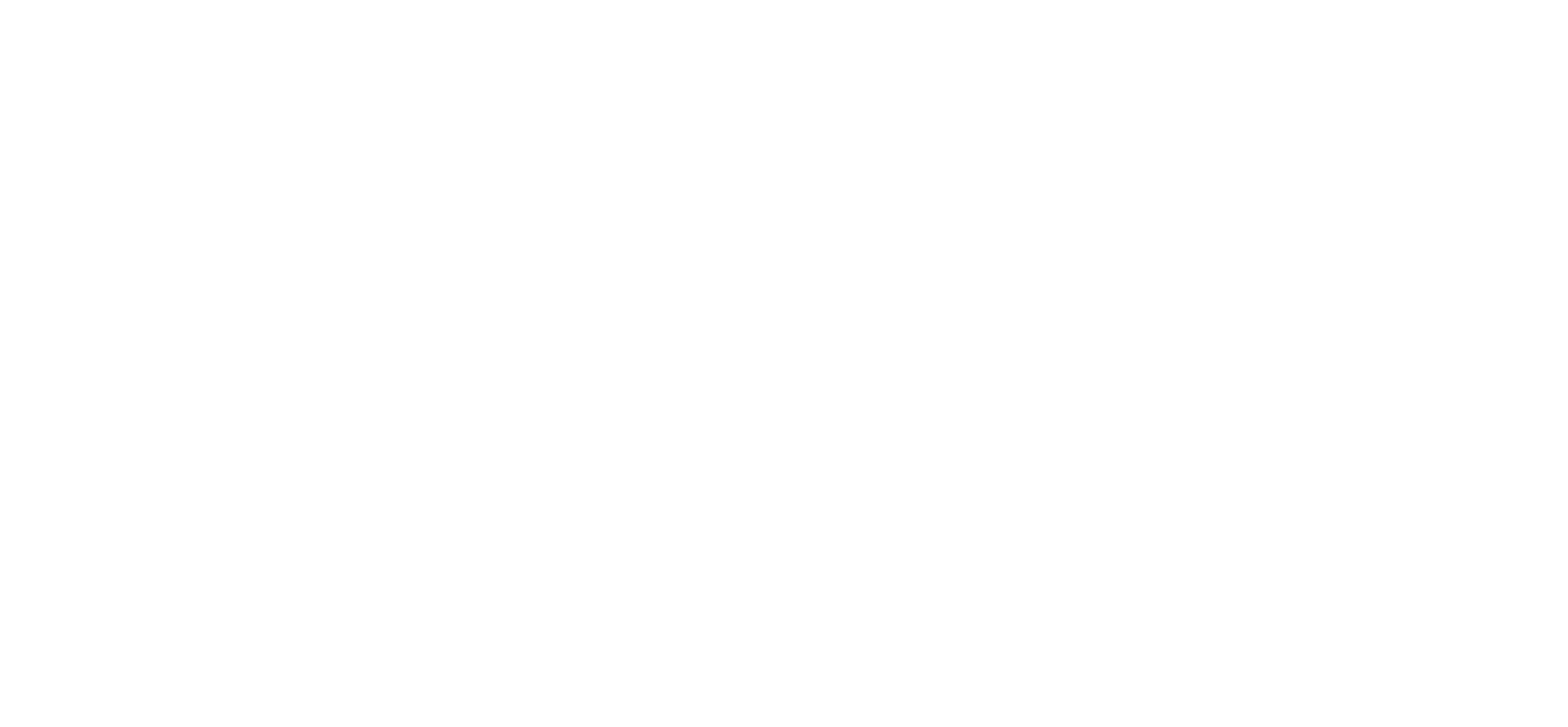

FIGURE 119.--View west across cirque at head of North Fork of La Sal Creek. Tp, diorite; Jm, Morrison formation.

and intruded by an irregular mass of diorite porphyry (fig. 119). In the divide between the head of La Sal Creek and Hell Canyon (SW $1 / 4$ sec. 23) the porphyry is overlain concordantly by beds in the middle part of the Morrison formation. The roof rocks dip about $35^{\circ} \mathrm{S}$. In the head of La Sal Creek, however, the contact trends northeast and is vertical and discordant. It trends about $45^{\circ}$ obliquely across the strike of sandstone beds in the lower part of the Morrison formation. In the $\mathrm{SE} 1 / 4$ of sec. 23 the contact cuts upward several hundred feet into the upper part of the middle unit of the Morrison formation. On the summit ridge this intrusion is in contact with other intrusions that have not been separated from it. The wedge-shaped outcrop of Morrison formation on the summit ridge at the very head of La Sal Creek and Hell Canyon may be the floor of the intrusion but it discordantly cuts these strata, crosses the summit ridge, and extends as an irregular dikelike mass northward into Gold Basin where it forms a ridge between two cirques.

The volume of these intrusions probably is only about 0.01 cubic mile.

\section{MOUNT PEALE LACCOLITH}

The Mount Peale laccolith underlies Mount Peale, the cirque at the head of Dark Canyon, and the summit ridge lying between the head of Dark Canyon and Gold Basin. This laccolith and the Mount Tukuhnikivatz laccolith are the largest on Middle Mountain. The Mount Peale laccolith extends 2 miles southeastward from the stock; it is 1 mile wide in the head of Dark Canyon and $1 \frac{11}{2}$ miles wide under Mount Peale. It intrudes the Morrison formation.
The roof of the laccolith is fairly well exposed around the sides of Mount Peale about 500 feet below the peak. The roof is sandstone belonging to the lower part of the Morrison formation. The peak is also capped by a sandstone bed that probably is in the middle or upper parts of the Morrison.

On Mount Peale the roof rocks dip $15^{\circ}-25^{\circ} \mathrm{W}$., and, except for minor irregularities, the contact at the top of the porphyry is concordant.

Westward from Mount Peale the roof rocks are cut discordantly by the porphyry along an essentially vertical but irregular contact trending somewhat east of south and crossing the summit ridge in the saddle 700 feet west of the peak. This porphyry may be a separate intrusion, but probably it is part of the Mount Peale laccolith that broke upward several hundred feet stratigraphically higher than the part of the laccolith underlying the peak. Its top, however, has been eroded, and its original form and extent must be inferred.

No roof rocks were found on that part of the laccolith that forms the ridge between Dark Canyon and Gold Basin.

The outcrops of porphyry along the east foot of Mount Peale probably are near the original distal edge of this intrusion. Close by are beds of sandstone, belonging in the lower part of the Morrison, that dip $50^{\circ}$ away from the intrusion.

The sides of the intrusion, along the northeast foot of Mount Peale and along the southwest side of the mountain, seem to be steep and discordant like the side walls of the Mount Tukuhnikivatz laccolith. Along the north foot of Mount Peale, in Dark Canyon, the beds nearest the porphyry are sandstone belonging to the lower part 
of the Morrison formation. On the west side of Dark Canyon the contact between the porphyry and Morrison is vertical and cuts upward to beds in the middle or upper parts of the Morrison.

West of Mount Peale, in the La Sal Creek drainage, the porphyry appears to rest concordantly on shale probably belonging to the middle part of the Morrison formation; a short distance southeast the porphyry seems to be on sandstone that is somewhat higher stratigraphically than the shale. These strata dip south more steeply than does the trace of the porphyry outcrop. The contact must dip steeply northeastward into the mountain and discordantly cut downward across the middle and lower parts of the Morrison.

In the cliffs at the north foot of Mount Peale and along the summit ridge between Dark Canyon and Gold Basin the diorite porphyry is jointed in vertical sheets that approximately parallel the north side of the laccolith. Linear structures within this part of the porphyry are roughly horizontal and parallel to the sheets. Along this zone of sheeted joints is weak pyritic alteration.

The volume of diorite porphyry in the Mount Peale laccolith probably is roughly 0.5 cubic mile.

\section{MOUNT MELLENTHEN LACCOLITHS}

Mount Mellenthin (pl. 44), one of the three high peaks in Middle Mountain, is the erosion remnant of two laccoliths, both of which are in the Mancos shale.

The floor of the southeasterly laccolith is exposed in the headward part of Horse Canyon, at the south foot of Mount Mellenthin, and in the cirque at the head of the valley draining to Blue Lake. The floor is Mancos shale, about 75 to 150 feet above the Dakota sandstone, and is baked to hornfels for 15 or 20 feet below the floor of the intrusion.

The steep distal edge of the laccolith is exposed on the northeast and southeast spurs of the mountain. This contact is irregular but dips about $75^{\circ}$ away from the intrusion. The shale exposed on the northeast spur is baked to hornfels that is crumpled and slickensided for 20 feet away from the contact. This shale contains numerous Gryphaea newberryi.

Diorite porphyry in contact with the shale has an inch selvage of crushed phenocrysts that are dragged linearly parallel to the dip of the contact but conform to irregularities in it.

In the head of the valley between these two spurs the floor is exposed. The porphyry for 100 to 200 feet above the floor is sheeted by vertical joints that trend somewhat south of west. Phenocrysts in the porphyry are crudely alined parallel to the sheeting and roughly horizontal.

Separating this laccolith from one that forms the northwest part of Mount Mellenthin is a band of Mancos shale that extends up the slope from Horse Canyon, crosses the summit about 200 feet west of the peak, and extends down the north slope for 200 or 300 feet. The shale is baked to hornfels but fragments of ammonites are still preserved in it. At the summit the shale dips $70^{\circ} \mathrm{W}$., but it is cut off on the north side of the mountain by the more steeply dipping floor of the laccolith to the west. Below the lower end of this band of shale and a few hundred feet northwest of it is an isolated block of Mancos shale dipping northwest. Except for this shale block, the two laccoliths are in contact with one another on the north slope of Mount Mellenthin and have not been separated.

The more western of the two Mount Mellenthin laccoliths appears to be less concordant than the eastern one. In the wall of Horse Canyon it is in contact with sandstone that is uppermost Morrison or Dakota, but northward the floor rises into the Mancos. Presumably this intrusion is phacolithic against the steep northwest flank of the eastern laccolith.

On the south side of Horse Canyon is an irregular mass of porphyry 750 feet wide and having side walls trending northeast. Northeastward this porphyry divides into three dikelike masses, which apparently fed the two Mount Mellenthin laccoliths. The map (pl. 39) shows two of the dikes crossing the canyon bottom where the rocks are concealed, but they may not extend that deeply into it; the dikes may have floors like the feeders to the Dorry Canyon laccolith. The middle of the three dikes, the one alined with the peak and probably the feeder for the southeast Mellenthin laccolith, appears to be separated on the outcrop from the laccolith. The dike cuts the Dakota sandstone but seems to end upward in Mancos shale.

Where the westerly dike joins the west Mellenthin laccolith, the porphyry has been hydrothermally altered.

The Mount Mellenthin laccoliths cover about threequarters of a square mile and have a maximum thickness of about 1,000 feet. Their volume, therefore, is about 0.15 cubic mile.

The seeming phacolithic relationship of the western laccolith to the eastern one, the alinement and location of the feeder dikes, the hydrothermal alteration on the southwest side of the western laccolith, and the internal structures along the east side of the eastern laccolith, all point towards the Gold Basin stock as being the source of these intrusions.

\section{BLUE LAKE LACCOLITH}

The Blue Lake laccolith is northeast of the Mount Mellenthin laccoliths and forms the high part of the ridge that extends northwest of Blue Lake. Along the 
north side of the ridge, shale belonging to the middle part of the Morrison formation is exposed below the laccolith and on its roof. The roof rocks dip $35^{\circ}$ and the floor dips $10^{\circ} \mathrm{W}$. near the foot of Mount Mellenthin. Eastward, however, the floor of the laccolith abruptly plunges eastward as if the laccolith were bent by a transverse fold trending about north. Part of this change in dip seems to reflect discordant intrusion because the east end of the porphyry is in sandstone at least 150 feet stratigraphically lower than the beds at the flexure. In the valley at the east foot of Mount Mellenthin the laccolith is much higher in the Morrison formation and perhaps in Mancos shale.

No exposures of the contacts were found along the south side of the ridge and possibly this laccolithic intrusion connects with the isolated mass of porphyry exposed on the next ridge 1,000 feet to the south.

The exposed part of the Blue Lake laccolith is only a couple of hundred feet thick. It is three-fourths of a mile long and one-fourth mile wide. How far it extends southwestward under the Mount Mellenthin laccoliths is not known. The volume of the exposed segment is about 0.01 cubic mile.

\section{INTRUSIONS IN HORSE CANYON}

At the head of Horse Canyon, on the summit ridge south of Mount Mellenthin, is a small but well-exposed laccolith in Mancos shale. The floor of the laccolith is nearly horizontal and about 100 feet above the base of the Mancos. The roof has been completely removed, so the original extent and form of the intrusion are not known.

The most interesting feature of this laccolith is the feeder dike that extends northwestward along the south wall of Horse Canyon where it connects with the conduits that fed the Mount Mellenthin laccoliths.

The intrusion covers only about 40 acres and the maximum thickness preserved is about 200 feet.

In the NW1/4 sec. 11, T. 27 S., R. 24 E., is a mass of slide-rock composed entirely of porphyry boulders, probably representing the frost-riven upper surface of an intrusion. Its general outlines, concordant with nearby ridges of sedimentary rocks, suggest that it is a sill. Its stratigraphic position is in the middle part of the Morrison formation.

\section{BRUMLEY RIDGE NOSELITE SYENITE PORPHYRY}

The noselite (sodalite?) syenite porphyry on the Brumley Ridge in secs. 4 and 9, T. 27 S., R. 24 E., is topographically part of Middle Mountain but petrographically this intrusion is quite unlike the other intrusions on Middle Mountain, which are exclusively diorite porphyry. Probably it is a part of the North Mountain feldspathoidal series. Whether the intrusion is a dike or a sill is not known. No contacts between it and the surrounding sedimentary rocks were found. The intrusion is in the middle part of the Morrison formation and forms a ridge 75 to 100 feet high.

At its southeast edge the intrusion forms a dikelike ridge, 200 feet wide and arcuate in plan. Southeastward this ridge ends in a cliff; northwestward it breaks off in a series of rockslides. The northwest limits of the intrusion are very ill defined because the downhill dip of the shale has caused sliding and masses of the porphyry have moved northwestward with the shale. Even on the highest part of the ridge, the porphyry has many open crevasses. Possibly the entire mass is out of position because of sliding on the shale.

The porphyry has a strongly developed platy structure but no orderly pattern was found in the orientation of the plates.

The rock is noselite or sodalite syenite porphyry containing about 35 percent large phenocrysts of perthite surrounded by a strongly lineated felt of orthoclase (about 50 percent), noselite (or sodalite?) (about 12 percent), and aegirine-augite (about 3 percent). In addition there is a trace of magnetite, apatite, and sphene. The phenocrysts of perthite are as large as 25 millimeters in diameter and are well rounded. The smaller ones average about 5 millimeters in diameter; these have sharp crystal edges but their corners are rounded.

\section{MTDDLE MOUNTAIN STOCK}

The laccoliths in Middle Mountain and the structures associated with them radiate from Gold Basin (pl. 44). The center of the igneous activity, and structural doming on Middle Mountain are in the east half of sec. 15 and west part of sec. 14, T. 27 S., R. 24 E. This area probably marks the surface of a stock that provided the source for the cubic mile or so of diorite porphyry contained in the dozen laccoliths clustered around this center. The central intrusion, however, is very poorly exposed and provides no direct evidence that it is a stock. The chief reason for the paucity of exposures is the glacial fill in Gold Basin.

All the igneous rocks exposed in Gold Basin are diorite porphyry, and only diorite porphyry was observed in the float downstream. Unaltered diorite porphyry is exposed at several places along the channel of Gold Creek and on the hillside north of the creek at the center of the east side of sec. 15. Other exposures of unaltered diorite porphyry are located at the edges of the cirque in the SW $1 / 4$ sec. 14 . In other parts of the basin the porphyry has been hydrothermally altered; 
the hornblende has been removed and pyrite or iron oxide deposited.

On the north wall of Gold Basin are masses of breccia composed of mixed fragments of sedimentary rock and diorite porphyry ranging from less than an inch to several feet in diameter. Exposures of the breccia are few but its float is abundant locally. Probably it represents a zone of shattering at the north wall of the stock, like the shatter zones that surround the stocks in the Henry Mountains.

One very curious mass of breccia, located in the $\mathrm{SE} / 4 \mathrm{NW} 1 / 4$ sec. 14 , is composed entirely of sedimentary rock in the form of a dike. It extends into the south side of the head of Horse Canyon and cuts through strata in the uppermost part of the Morrison formation, Dakota sandstone, and lowermost Mancos shale. The dikelike mass is 20 feet wide at the canyon rim but narrows down the slope. It is composed of angular and rounded pebbles and cobbles of carbonaceous shale and carbonaceous sandstone evidently derived from the Dakota and of purple shale evidently from the Morrison.

Other small masses of breccia composed of mixed sedimentary and igneous rocks are exposed near the southeast corner of sec. 15 and probably mark the south side of the stock.

The east wall of the stock is fairly well defined where it crosses the hillside in the NW1/4W $1 \frac{1}{4}$ sec. 14 . Here, breccia and hydrothermally altered porphyry cut discordantly upward from the middle of the lower sandstone unit to the top of the middle shale unit of the Morrison formation. Shale adjoining this wall of the stock is baked to hornfels for a few hundred feet east of the contact. Breccia, hydrothermally altered porphyry, and some sulfide mineralization occur in the stock along this wall. Except for this exposure, the limits of the stock in Gold Basin as shown on the map are arbitrary. The areal extent as shown on plate 39 is about 0.4 square mile; its volume to a depth equal to the height of the Middle Mountain dome $(3,500$ feet) is about 0.3 cubic mile.

Many prospect pits in Gold Basin expose porphyry that has been hydrothermally altered. The alteration has largely removed the ferromagnesian minerals and partly argillized the feldspar. Pyrite is common and there is some chalcopyrite. Specular hematite and epidote occur in the rocks surrounding Gold Basin. The hydrothermal alteration is neither intensive nor extensive, but it is much more so than in any of the laccoliths. Pyritic alteration is restricted to Gold Basin.

\section{SOUTH MOUNTAIN}

South Mountain, topographically the smallest of the La Sal Mountains, covers about 15 square miles, mostly in the north part of T. 28 S., R. 24 E. Both topographically and structurally the mountain is elongated to the northwest and southeast.

The oldest sedimentary rocks on the mountain are Triassic or older and are exposed along the southwest flank of the mountain. Mancos shale of Late Cretaceous age is the youngest preserved formation involved in the doming. The intrusions are mostly diorite porphyry but include some small masses of monzonite porphyry.

At the center of the mountain is a stock, about 1 mile in diameter, that discordantly cuts across Triassic, Jurassic, and Cretaceous formations. This crosscutting amounts to about 2,500 feet of beds in a mile. Surrounding the stock is a series of irregular intrusions, presumably laccolithic and injected outward from the stock. These satellitic intrusions extend $2 \frac{1}{2}$ miles southeast from the stock and more than 1 mile northwest from it, but to the southwest and northeast they are short.

The intrusive rocks in South Mountain aggregate about 3.3 cubic miles. Of this amount 1.50 cubic miles are contained in the stock down to a depth equal to the height of the South Mountain dome. About 1.8 cubic miles are contained in the satellitic intrusions that were pushed out laterally from the stock. Practically all this rock is diorite prophyry, like that on North Mountain (p. 319), but there are some small younger intrusions of monzonite porphyry, probably more than shown on plate 39 .

\section{PACK CREEK LACCOLTTH}

The Pack Creek laccolith is on the south side of Pack Creek mostly in secs. 32 and 33 . Only the upper part of the intrusion, covering about one-fourth of a square mile, is exposed. It forms a ridge between Pack Creek and a small tributary from the south. The laccolith is intruded into beds of Triassic age near the base of the Glen Canyon group, which is folded anticlinally across the laccolith.

The anticline produced by the laccolith is about 2 miles long, 1 mile wide, and has a structural relief of perhaps 1,000 feet. It trends and plunges northwestward from the stock. The volume of the intrusion is 0.25 cubic mile.

\section{LACCOLTTH SOUTHEAST OF THE STOCK}

A laccolith southeast of the stock and located between Deer Creek and East Pole Canyon, is roofed by sand- 
stone belonging to the Glen Canyon group. At the mouth of East Pole Canyon the intrusion appears to cut discordantly across Triassic and possibly older rocks.

The distal end of this laccolith is lobate in plan. The intrusion, which probably extends northward under the sandstone capped ridge between Deer and La Sal Creeks, is about 1 mile wide, almost 3 miles long, and probably averages nearly 1,000 feet thick. Its volume is 0.5 cubic mile.

This laccolith abuts against the intrusion west of East Pole Canyon and may be simply a bulging part of it.

\section{INTRUSIONS SOUTH AND WEST OF THE STOCK}

South and west of the stock and extending from East Pole Canyon to West Pole Canyon is a large intrusion or series of intrusions. The southwest side of the intrusive mass is concordant with the steep southwest flank of the South Mountain dome and dips about $65^{\circ}$ away from the stock. It is roofed by Triassic or older rocks.

The volume of these intrusive masses must be at least 1 cubic mile.

\section{INTRUSIONS NORTHEAST OF THE STOCK}

Extending northeastward from the stock is a crosscutting porphyry mass that feeds at least 3 sill-like intrusions in the uppermost Morrison and Upper Cretaceous strata. One of the sills extends more than $1 \frac{1}{2}$ miles eastward. It starts in the Dakota sandstone but cuts upward into the Mancos.

Two other sills are in the steeply dipping beds at the head of Pack Creek.

\section{SOUTH MOUNTAIN STOCK}

The South Mountain stock, at the center of the South Mountain cluster of intrusions, centers around the head of Lackey Basin. The peak of South Mountain, at an altitude of almost 11,800 feet, is in the stock. Lackey Basin is eroded more than 1,500 feet into the south part of the stock and a cirque has been eroded a thousand feet or more into the northeast part of the stock. A smaller cirque is located on the northwest side of the stock. Around the sides of these basins, exposures are excellent.

The stock is roughly circular in plan. Its side walls are reasonably well defined on the northwest side where the stock discordantly cuts across 2,500 feet of Triassic, Jurassic, and Cretaceous strata. The contact was found exposed only in the $\mathrm{SW} / 4 \mathrm{SE} / 4$ sec. $33, \mathrm{~T} .27 \mathrm{~S}$., R. 24 E., where it dips $65^{\circ}$ towards the intrusion. The wall here is shattered sandstone belonging to the Glen Canyon group or Entrada sandstone.

On the south side of the stock, in Lackey Basin, and on the ridge to the west are small masses of brecciated sedimentary rocks and porphyry probably marking the south wall of the stock. Between these brecciated masses the porphyry of the stock appears to be continuous with that of the intrusions to the south and west.

Several textural varieties of porphyry were found in the stock but the boundaries between them were not mapped. A small mass of monzonite porphyry, elongated to the northeast and apparently dipping steeply southeast, was found in the upper part of Lackey Basin.

Near the northeast and north walls the stock is sheeted by vertical or nearly vertical joints through a zone about 500 feet wide parallel to the walls. Some narrow fissures within the stock contain pyrite, hematite, and copper carbonate.

\section{SUMMARY COMPARISON OF THE VOLUMES AND} POSITIONS OF THE INTRUSIONS

The following table presents in summary form the dimensions, volumes, and stratigraphic positions of the intrusions in the La Sal Mountains. 
TABLE 3.-Dimensions, volume, and stratigraphic positions of intrusions in the La Sal Mountains

\begin{tabular}{|c|c|c|c|c|c|}
\hline \multirow{2}{*}{ Intrusion } & \multicolumn{3}{|c|}{ Dimensions, in miles } & \multirow{2}{*}{$\begin{array}{l}\text { Estimated } \\
\text { volume } \\
\text { (cubic miles) }\end{array}$} & \multirow{2}{*}{ Youngest rocks cut by intrusion } \\
\hline & Length & Width & $\begin{array}{l}\text { Maximum } \\
\text { thickness }\end{array}$ & & \\
\hline \multirow[t]{3}{*}{$\begin{array}{l}\text { North Mountain: } \\
\text { Laccoliths southeast of the stock } \\
\text { Laccoliths southwest of the stock } \\
\text { Haystack Mountain laccolith } \\
\text { Mill Creek sill } \\
\text { Laccoliths northwest of the stock } \\
\text { Laccoliths northeast of the stock } \\
\text { Beaver Creek laccolith } \\
\text { Round Mountain bysmalith } \\
\text { Total diorite porphyry laccoliths }\end{array}$} & $\begin{array}{l}3.0 \\
2.0 \\
1.0 \\
3.5 \\
3.5 \\
2.0 \\
3.0\end{array}$ & $\begin{array}{r}1.5 \\
2.75 \\
1.0 \\
.2 \\
1.5 \\
3.5 \\
.5\end{array}$ & $\begin{array}{l}0.5 \\
.5 \\
.25 \\
.02 \\
.6 \\
.4 \\
.1 \\
\end{array}$ & $\begin{array}{r}1.25 \\
1.25 \\
.10 \\
.02 \\
1.50 \\
.80 \\
.15 \\
<.02\end{array}$ & $\begin{array}{l}\text { Pennsylvanian. } \\
\text { Do. } \\
\text { Upper Cretaceous. } \\
\text { Do. } \\
\text { Pennsylvanian. } \\
\text { Triassic or older. } \\
\text { Upper Cretaceous. } \\
\text { Pennsylvanian. }\end{array}$ \\
\hline & $-\ldots+\ldots$ & $\mid-\ldots+\ldots$ & -....... & 5. $00+$ & \\
\hline & $\ldots \ldots$ & 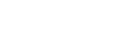 & {$[\ldots$} & .5 & Diorite porphyry. \\
\hline $\begin{array}{l}\text { North La Sal stock: } \\
\text { Diorite porphyry } \\
\text { Dike-swarm complex } \\
\text { Feldspathoidal dikes } \\
\text { Soda syenite porphyry } \\
\text { Aegirine granite porphyry } \\
\text { Soda rhyolite porphyry dikes. }\end{array}$ & 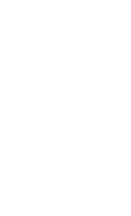 & 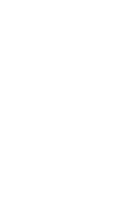 & 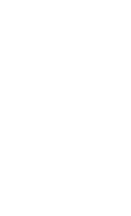 & $\begin{array}{l}5 \\
7 \\
.02 \\
.15 \\
.10 \\
02\end{array}$ & $\begin{array}{l}\text { Monzonite porphyry. } \\
\text { Dike-swarm complex. } \\
\text { Do. } \\
\text { Feldspathoidal dikes. } \\
\text { Aegirine granite porphyry. }\end{array}$ \\
\hline Total North La Sal stock & 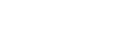 & 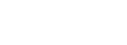 & (........... & 1. 50 & \\
\hline Total North Mountain intrusions............. & -- & & $-\ldots$ & 7. 00 & \\
\hline $\begin{array}{l}\text { Middle Mountain: } \\
\text { Brumley Creek laccolith } \\
\text { Dorry Canyon laccolith } \\
\text { Mount Tukuhnikivatz laccolith } \\
\text { Intrusions at head of La Sal Creek } \\
\text { Mount Peale laccolith } \\
\text { Mount Mellenthin, Horse Canyon, and Blue Lake } \\
\text { laccoliths. } \\
\text { Middle Mountain stock }\end{array}$ & $\begin{array}{l}\text { 1. } 5 \\
\text { 1. } 5 \\
\text { 1. } 5 \\
\begin{array}{l}2.0 \\
1.0\end{array}\end{array}$ & $\begin{array}{l}\text { 1. } 0 \\
\text { 1. } 0 \\
-1.25 \\
\text { 1. } 0\end{array}$ & $\begin{array}{c}.1 \\
.1 \\
.4 \\
-.4 \\
.2\end{array}$ & $\begin{array}{l}.03 \\
05 \\
.60 \\
.01 \\
50 \\
.20 \\
.30\end{array}$ & $\begin{array}{l}\text { Upper Jurassic. } \\
\text { Do. } \\
\text { Do. } \\
\text { Do. } \\
\text { Do. } \\
\text { Upper Cretaceous. } \\
\text { Discordant. }\end{array}$ \\
\hline Total Middle Mountain & 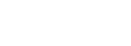 & 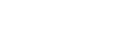 & - & 1. 70 & \\
\hline $\begin{array}{l}\text { South Mountain: } \\
\text { Pack Creek laccolith } \\
\text { Laccolith southeast of the stock } \\
\text { Intrusions south and west of stock } \\
\text { Intrusions northeast of stock } \\
\text { South Mountain stock }\end{array}$ & $\begin{array}{l}\text { 2. } 0 \\
\text { 3. } 0 \\
\text { 1. } 0 \\
\text { 2. } 0 \\
\text { 1. } 25\end{array}$ & $\begin{array}{l}.5 \\
\text { 1. } 0 \\
\text { 3. } 0 \\
.5 \\
\text { 1. } 25\end{array}$ & $\begin{array}{r}.2 \\
.2 \\
.5 \\
.1 \\
- \\
-\end{array}$ & $\begin{aligned} .25 \\
.50 \\
1.0 \\
.05 \\
\text { 1. } 50\end{aligned}$ & $\begin{array}{l}\text { Pennsylvanian. } \\
\text { Do. } \\
\text { Do. } \\
\text { Upper Cretaceous. } \\
\text { Discordant. }\end{array}$ \\
\hline Total South Mountain & $-\cdots---$ & 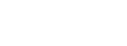 & 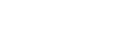 & 3.30 & \\
\hline Total La Sal Mountains & - & $(-\ldots+\ldots$ & 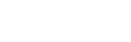 & 12. 00 & \\
\hline
\end{tabular}


For further comparisons that may be made, the estimated volumes of intrusive rock in the five Henry Mountains are given in the following table:

TABLE 4.-Estimated volumes of intrusive rock in the Henry Mountains

\begin{tabular}{l|r|r|r}
\hline \multirow{2}{*}{ Mountain } & \multicolumn{3}{|c}{ Volume, in cubic miles } \\
\cline { 2 - 4 } & Laccoliths & \multicolumn{1}{c|}{ Stock } & \multicolumn{1}{c}{ Total } \\
\hline Mount Holmes & & & \\
Mount Ellsworth & 0.20 & 0.06 & 0.26 \\
Mount Pennell & .35 & .26 & .61 \\
Mount Hillers & 1.18 & 2.25 & 3.43 \\
Mount Ellen..82 & 2.44 & 4.26 \\
\hline
\end{tabular}

\section{ORIGIN AND EVOLUTION OF THE MAGMAS}

By Aaron C. Waters and Charles B. Hunt

The ultimate source of the parent magma that gave rise to the La Sal laccolithic complex can only be surmised, for the site of magma generation was far below the levels now exposed by erosion. From indirect evidence, however, a few tentative suggestions can be offered.

\section{INADEQUACY OF CRYSTALLIZATION DIFFERENTIA- TION OF BASAIT}

Basaltic magma has clearly had a part in the development of many igneous centers containing a diversity of rock varieties. The theory that basalt is the primary magma from which other rock varieties were formed by differentiation is strongly substantiated not only by field evidence but by laboratory studies and theoretical deductions as well (Bowen, 1928). Was basalt the primary parent from which the varied igneous suite of the La Sal Mountains evolved by crystallization differentiation or other igneous processes?

The field evidence on this point is entirely negative. Basalt (and its plutonic equivalents gabbro and dolerite) are entirely absent from the La Sal suite of igneous rocks. Nor have they been found as components of the igneous sequence at the other laccolithic centers of the Colorado Plateau except possibly in the Henry Mountains, where fragments of a sill of greatly altered basalt occur at one place in the shatter zone around the Mount Ellen stock (Hunt, C. B., 1953), and in the La Plata Mountains where there are some curious maficrich dike rocks (Eckel, 1949). Several of the laccolithic complexes now have been mapped, but no field evidence has been found to indicate that basalt magma was ever present within any of the stocks or laccolithic chambers. Furthermore, although the stocks and laccoliths contain abundant inclusions, none have been found that could be interpreted as autoliths of gabbroic type.

The change in composition of the La Sal magma with time is also not that which might be expected if these rocks had been formed by the crystallization differentiation of basalt magma. Here, however, we are on less firm ground, as it is well known that differentiation processes operating on primary basalt magma have given rise to quite different suites of rocks at different localities. The sequence of intrusions at the La Sal Mountains can be diagrammatically pictured as follows (see also fig. 120):

Diorite $\rightarrow$ monzonite $\rightarrow$ syenite $\rightarrow$ feldspathoidal syenite $\rightarrow$ carbonatite (calcite veins)

Quartz syenite $\rightarrow$ aegerine granite and soda rhyolite $\rightarrow$ quartz veins and miarolitic cavity fillings

This sequence contrasts strikingly with well-established igneous sequences in which primary basaltic magma seems to have had an important part. For example, a typical sequence well shown by many circum-Pacific volcanoes is:

Olivine basalt<smiles>C[AlH2]</smiles>

hypersthene basaltic andesite<smiles></smiles>

andesite

$\searrow$

dacite

In Hawaii (Macdonald, 1949) and other oceanic islands a common sequence is:

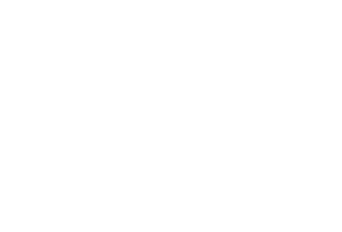

Locally, in the Pacific a subordinate stem gives rise to mellitite and nepheline basalt or, rarely, to phonolite.

Another sequence-dolerite or gabbo (and norite) $\rightarrow$ granophyre-with no intermediate rocks of dioritic or monzonitic composition, is well known from basic sills the world over, and is also common in volcanic rocks as, for example, in the sequence tholeiitic basalt $\rightarrow$ rhyolite in Iceland.

The larger lopoliths and "stratiform complexes" are generally more thoroughly differentiated:

Liquid line of descent:

Gabbro (or norite) $\rightarrow$ diorite $\rightarrow$ syenite (and quartz syenite)

Crystal accumulates:

Dunite

Peridotite

Pyroxenite

Anorthosite

Magnetite and chrome ores

The Skaergaard intrusion differentiated from gabbro 

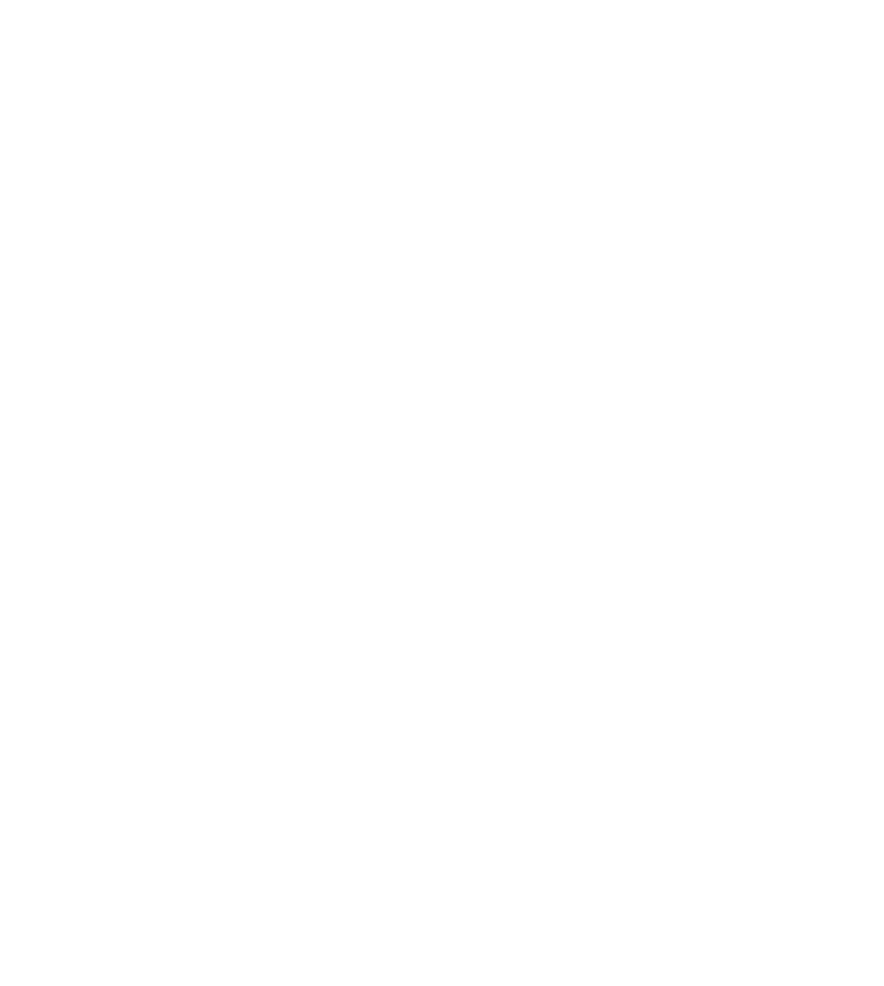

FIGURE 120.-Graphs showing variations in alkali and silica content of the differentiation sequence in North Mountain.

to ferrogabbro with gradual increase of soda and iron in the late differentiates (Wager and Deer, 1939).

These typical sequences resulting from the crystallization differentiation (plus local hybridization?) of basaltic magma differ from the sequence in the La Sal Mountains not only in the kind of rocks produced but also in the order of formation of individual minerals. The sequence of crystallization from a differentiating basalt magma in its course down the "liquid line of descent" is, with minor variations, the well-known Bowen reaction series (Bowen, 1928, p. 60). The order of the ferromagnesian minerals is from olivine to pyroxene to hornblende to biotite; that of the feldspars is from calcic plagioclase to sodic plagioclase, with potash feldspars also appearing near the end of crystallization. In the La Sal rocks, on the other hand, this mineral sequence for the ferromagnesians is reversed. It progresses from hornblende (in diorite porphyry) to augite and aegirine-augite (in monzonite and soda syenite porphyry) to aegirine-augite and aegirine (in soda syenite, feldspathoidal syenites, aegirene granite, and soda rhyolite porphyries). Also the plagioclase shows no marked fractionation from calcic to sodic types-oligoclase is the chief feldspar and is present in all rocks. The chief change in the feldspar content is in the ratio of oligoclase to potash feldspar, the sequence in time being oligoclase to anorthoclase and sanidine (or perthite). This change in the feldspar is in approximate conformity with the late stages of Bowen's sequence.

Irregular replacement or jacketing of hornblende by augite or by aegirine-augite is common in the La Sal rocks; this is a phenomenon that would indicate a rise of temperature instead of continued crystallization differentiation. A rise in temperature also is indicated by the evidence (Hunt, C. B., 1953) that the temperature of the diorite porphyry melt apparently was near the theoretical lower limit for such magma, perhaps little, if any, above $500^{\circ} \mathrm{C}$, whereas the soda rhyolite and aegirine granite porphyries contain high-temperature quartz.

Furthermore, in normal differentiation sequences of basalt there is a progressive increase in the silica content. The rocks of the La Sal and Henry Mountains, on the contrary, show a gradual decrease in silica from diorite to monzonite to feldspathoidal syenite (fig. 120). In the La Sal Mountain rocks, however, there is a marked increase in silica in the last formed soda rhyolite and aegirine granite porphyries.

Thus on both field and physical-chemical grounds the evidence suggests that the La Sal magmas did not evolve from a primary basaltic magma by crystallization differentiation.

\section{EVIDENCE FROM INCLUSIONS}

A hint as to a possible alternative explanation can be gained from the study of inclusions within the igneous rocks. In the Henry Mountains, Hunt (1953) studied the kinds and quantities of the inclusions. There, and also in the La Sal Mountains about 5 percent are obvious xenoliths derived almost entirely from the enclosing sedimentary rocks but containing a few unmodified granites and schists from the crystalline basement. These xenoliths show no contact-metamorphic effects except for a mild induration. They are free of reaction effects, and the hornblende and plagioclase with which the surrounding magma was saturated is not in equilibrium with them, nor has it precipitated upon them as "seed" centers. In short, the evidence indicates that these inclusions were merely mechanically incorporated into a crystallizing magma that was too cold to metamorphose them effectively or change their composition.

On the other hand the great bulk (95 percent) of the inclusions contrast strikingly with these little-altered sedimentary xenoliths. The most abundant are amphibolite inclusions which comprise perhaps 1 percent of the total volume of the diorite porphyry intrusions. The amphibolite inclusions show evidence of having attained almost complete equilibrium with the surrounding magma. The hornblende content ranges from 20 to 100 percent and averages about 75 percent. 
The other main mineral is plagioclase which almost invariably has the same composition as the plagioclase in the surrounding intrusive; this is particularly striking because the composition of the plagioclase varies somewhat from one intrusion to another. Other minerals present in many inclusions, but not common to all, are garnet and biotite. If the surrounding igneous rock contains aegirine-augite, this mineral is also likely to be found in some of the hornblendic inclusions. Here, as in the surrounding igneous rock, the aegirine-augite is clearly later than hornblende, which it replaces in intricate interfingering patterns governed in part by cleavage planes and grain boundaries.

Some of these mineralogic relations are consistent with the idea that the amphibolite inclusions might be autoliths formed by the segregation of early crystallizing constituents of the magma into glomeroporphyritic clots. There is, however, convincing evidence against this mode of origin. A great many of the inclusions show relic metamorphic textures and structures, especially gneissic banding and schistosity. Such relic structures are more common and more distinct in inclusions that contain less than 75 percent hornblende; in the more hornblendic types original structures appear to have been largely obliterated by continued grain growth of the hornblende. Most inclusions are angular, though some of the richly hornblendic kinds appear to have been softened and strung out or disintegrated into smaller pieces. Where relic bands are preserved, the banding in different inclusions is not parallel but stands at all angles. Many inclusions are cut by veins that are in turn truncated by the enclosing porphyry. The occurrence of large blocks of partly replaced and partly assimilated Precambrian rocks in the soda syenite of the North La Sal stock provides important additional evidence that the hornblendic xenoliths were derived from preexisting amphibolites and similar ferromagnesianrich rocks and are not cognate segregations from the magma.

Table 5 presents a summary description of variations in the mineral composition, size, shape, grain size, and texture of the inclusions.

TABLE 5.-Statistical study of 85 inclusions in diorite porphyry float in the La Sal Mountains

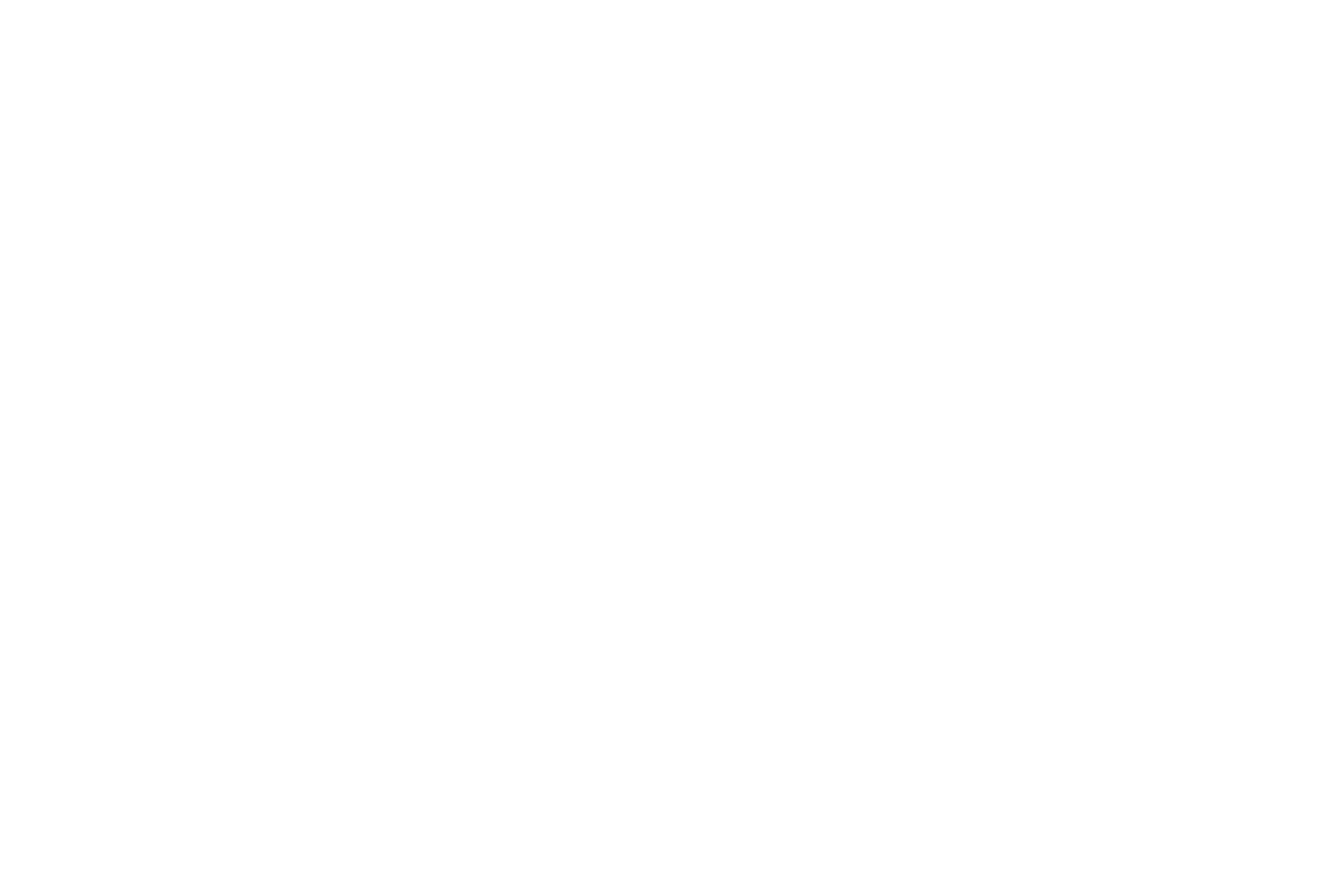


STRUCTURAL AND IGNEOUS GEOLOGY OF THE LA SAL MOUNTAINS, UTAH

TABLE 5.-Statistical study of 85 inclusions in diorite porphyry float in the La Sal Mountains-Continued

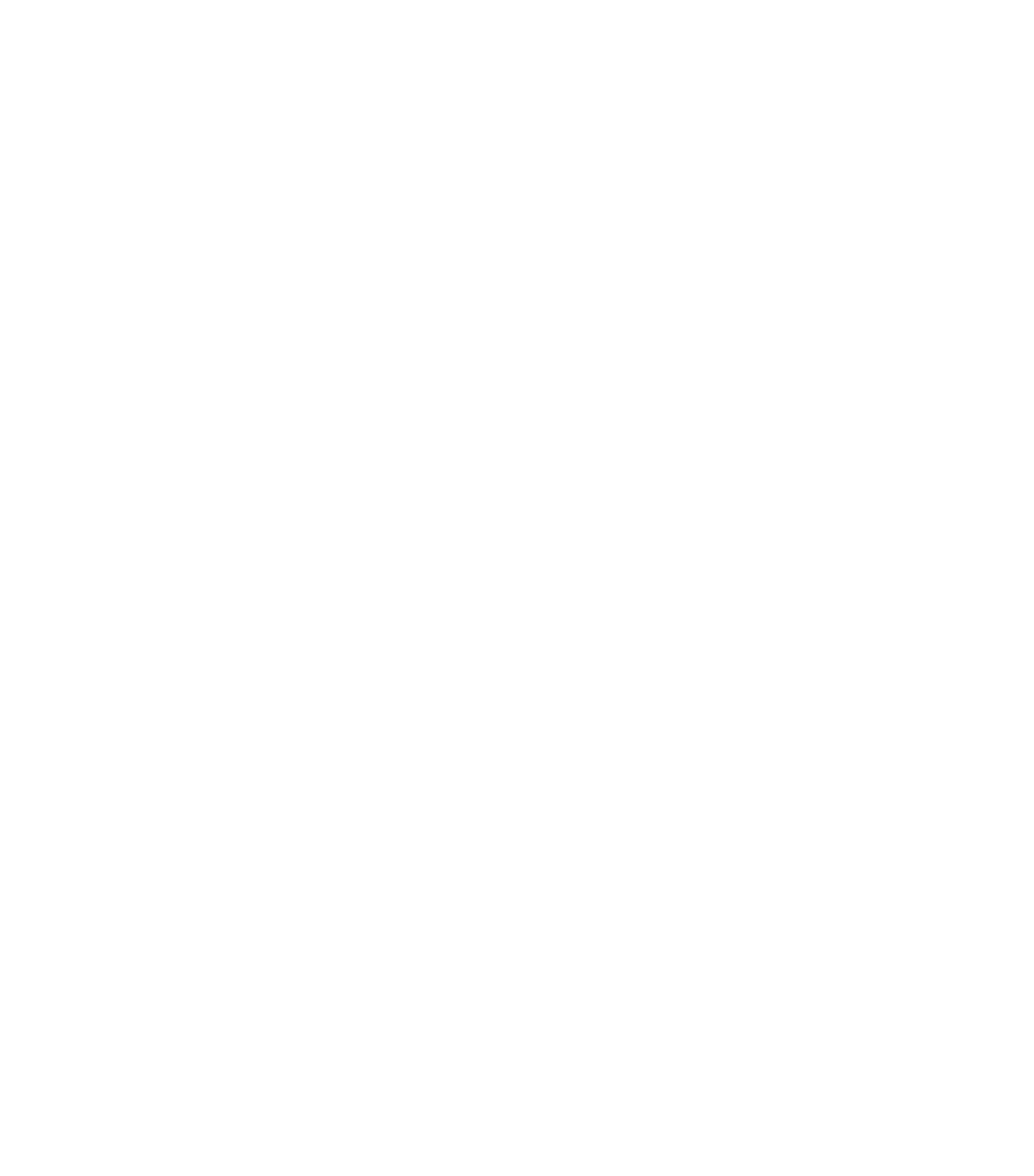




\section{PALINGENESIS OF AMPHIBOLITE}

These physical relations suggest an alternative explanation: Perhaps the original diorite magma was formed by the selective fusion (palingenesis) of a metamorphic sequence of which the hornblendic inclusions represent refractory remnants that were not actually incorporated into the liquid magma but were, in large part, "made over" into minerals with which the surrounding magma was in equilibrium (Bowen, 1922). The visible fragments have been rafted upward from the site of magma generation and are now frozen into their present position within the stocks and laccoliths.

It is very difficult to determine whether these secondary changes and mineral transformations occurred at depth, and hence might be connected with the development of the diorite porphyry magma by palingenesis, or whether they are the result of longcontinued reactions in a magma of different origin which plucked amphibolites from its wall and then altered them during its long ascent toward the surface. In favor of the palingenetic theory is the fact that in the La Sal Mountains, just as in the Henry Mountains, there is no transition between the highly altered hornblendic inclusions and the somewhat indurated but otherwise almost totally unaltered xenoliths of sedimentary rocks. The lack of any transition in alteration between the obvious xenoliths and the hornblendic inclusions strongly suggests that the latter came from great depths and have had an entirely different history from that of xenoliths incorporated at higher levels. Either they are fragments of diverse wall rocks brought to equilibrium with a magma at great depths, or else they are the leftover unfused fragments of the substratum from which the magma itself was derived - or perhaps both.

\section{SOME PHYSICAL-CHEMICAL DEDUCTIONS}

Assuming that the diorite porphyry magma was formed by selective fusion of amphibolite and associated metamorphic rocks, certain consequences can be deduced that may serve as a partial check on the hypothesis. If a metamorphic series of basic rocks approximating the composition of basalt underwent slow palingenesis until an interstitial dioritic liquid was formed, the remaining unfused constituents of the amphibolite would consist largely of undissolved hornblende-in fact the remaining unfused part of a typical amphibolite should have approximately the composition of the smaller hornblende-rich inclusions found in abundance within the Henry and La Sal intrusions. What would then be the result of a rise in temperature and additional solution of a part of the remaining hornblende?
Bowen (1928) considered the effects of fractional dissolving of hornblende and biotite crystals settling by gravity to a hotter and deeper zone within a magmatic mass, and he discusses the consequences of partial resolution of this igneous hornblende into the magma of the deeper zone. The principle involved can be applied as well to the problem of solution of hornblendic fragments in a partial magma formed by the selective fusion of amphibolite.

Whereas a magma like diorite will "make over" minerals such as olivine and pyroxene that are higher in the reaction series than the ones with which the magma is saturated, its effects on hornblende and biotite present a more complex problem (Bowen, 1928, p. 269273). Bowen calls attention to the fact that hornblende is a very basic mineral and also a highly complex one. He states:

We should expect hornblende, sinking into a region of somewhat. hotter liquid, not to be redissolved as such, except in quite small amount, but rather to enter into reactions which precipitate, as crystals, earlier minerals in the reaction series $* * *$. If a large amount of hornblende suffers such action there should result an enrichment of the liquid in all the constituents of hornblende other than those precipitated during the reaction.

The norms of 10 hornblendites selected from Washington's tables (Bowen, 1928, p. 271) show considerable amounts of nepheline and albite as well as large amounts of diopside, anorthite, and olivine. All contain small amounts of normative orthoclase or leucite (or both). Bowen concluded:

Of the normative minerals listed, albite and orthoclase are late members of the ordinary reaction series and their tendency would be to become part of the "hot" liquid *** nephelite is. a rather important constituent of nearly all the norms $* * *$ nephelite is capable of forming with diopside a liquid of quite low melting temperature, so it is to be expected that nephelite together with a nearly equivalent weight of diopside could enter the liquid. Probably the small amounts of leucite shown in some of the norms $* * *$ would tend to pass into the liquid also. On the other hand, olivine, excess of pyroxene and perhaps basic plagioclase would tend to be precipitated by the "hot" liquid.

In short, the effect is to fractionate hornblende into. two parts: A strongly alkalic portion (approximately the normative albite, orthoclase, leucite, nepheline, and a part of the diopside) which dissolves in the liquid; and a residual solid precipitate (consisting of the normative olivine, hypersthene, and a part of the anorthite and diopside). In our assumed case of the partial fusion of amphibolite beneath the La Sal Mountains, the tendency would be to produce first a liquid of dioritic composition and then as more hornblende partially dissolved to make this liquid more definitely alkalic. The remaining unfused amphibolite would simultaneously be transformed to a more basic composition. 
Regarding the solution of biotite Bowen writes (1928, p. 271):

The sinking of biotite, either alone or with hornblende, and its reactive solution in "hot" liquid should be regarded in the same general way. Biotite may be regarded as made up of highly femic molecules, mainly olivine, that would be precipitated and alkalic molecules that would in large part enter the liquid.

\section{FIELD EVIDENCE}

These physical-chemical deductions can now be compared with the field relations in the La Sal and Henry Mountains. In good accord is the clear-cut field and petrographic record of replacement of hornblende by augite (or aegirine-augite) in both the magma and the solid hornblendic inclusions. Also in good accord is the transition of the magma from diorite to monzonite to syenite to feldspathoidal syenite; it clearly exhibits the tendency to become more alkalic-predicted as a result of continued partial solution of hornblende.

Bowen, however, suggests that the partial solution of large quantities of hornblende should result in a thoroughly basic alkalic magma, such as the nephelinites, alnoites, or olivine-rich lamprophyres. The silica content of the La Sal rocks (unlike the typical suites thought to have been formed by crystallization differentiation of basaltic magma) changes only slightly during the transition (fig. 120). All these rocks are of mesosilicic type, and nowhere in the La Sal Mountains are strongly mafic alkalic rocks developed. Precisely the kind of strongly mafic alkalic rocks that Bowen suggests, however, are widespread in the Navajo and Hopi volcanic fields in the southern part of the Colorado Plateau (Williams, 1936). These relations are treated more fully in a report by Hunt (1956) on the Cenozoic geology of the plateau.

Perhaps an answer to the absence of strongly mafic alkalic rocks in the laccolithic complexes is to be found in the effects of filtration differentiation during rise and emplacement of the magmas at their present high levels in the crust. Chilled contacts show that even the earliest rocks of the La Sal Mountains are strongly porphyritic, indicating that partial crystallization had occurred before the magma entered the visible chambers. During rise and intrusion the liquid portions would be expected to advance more rapidly and to higher levels than the solid constituents. Thus the early formed phenocrysts and the included fragments of unfused basement would tend to lag behind. Furthermore, with the onset of crystallization the magma would probably precipitate hornblende and other early crystallizing minerals upon the hornblende inclusions, thus decreasing the amount of femic material in the rest magma and causing the hornblendic inclusions to grow and clot together. By a combination of these processes the magma may have freed itself of large quantities of early crystallizing femic and anorthitic constituents.

That such filtration effects actually did occur is strikingly displayed by the field and petrographic relations of some of the strongly porphyritic igneous masses in the North La Sal stock. The intrusion of the syenitic dike swarm occurred during the later stages of the magmatic history as the top of the stock slowly congealed and then was repeatedly cracked. It is noteworthy that the last dikes of this swarm are highly alkalic feldspathoidal varieties which probably represent the segregation of alkalic residues in late filtrates. The highly porphyritic soda syenite of Mineral Mountain shows obvious filtration effects (fig. 111).

\section{ORIGIN OF THE QUARTZ-RICH DIFFERENTIATE}

The idea of magma generation by selective melting of amphibolite followed by continued partial solution of hornblende and of the fractionation of the alkalic magmas thus formed by filtration differentiation during rise to present crustal levels seems to accord with the field relations. But the hypothesis of palingenetic derivation and evolution seems to hold only for the sequence from diorite porphyry to feldspathoidal syenite; it would not account for the late quartz-rich aegirine granite and soda rhyolite porphyries.

It is noteworthy, however, that the quartz-rich rocks are confined almost entirely to the final volcanic phase in the development of the North La Sal stock. They occur as fillings of the volcanic diatremes, as a brecciated rubble within the diatremes, and as dikes that cut, or are closely related to, individual diatremes. Quartz-filled cavities are abundant in the aegirine granite porphyry associated with the diatremes; quartz also fills the angular spaces between the breccia fragments within the diatremes. It seems that the initiation of a volcanic cycle during the closing phases of consolidation of the stock brought about a change in the evolution of the magma that led to the development of quartz-rich types.

If the stock and substratum were almost crystallized at the onset of the volcanic cycle the gas pressure in the remaining rest magma would be very high, and relief of pressure by bursting of the roof to form a volcano would be likely to start violent evolution of gas (retrograde boiling) in the still liquid residues of the stock. If the palingenetic melts in the substratum were also nearing final solidification at about this time, they, too, might send vast amounts of tenuous fluids streaming upward through the stock.

Field evidence of the passage of such exhalations upward toward the surface is widespread. As previ- 
ously noted, the older diorite porphyry of the North La Sal stock is drastically altered to metadiorite. Feldspars and homblende are thoroughly decomposed, and joints in the rock are commonly coated with mixtures of hedenbergite, actinolite, and epidote. At the very top of the stock the joints are filled with an intricate network of quartz veinlets. Similar, though less drastic, alteration also affects the syenite and other rocks of the stock. By contrast, laccoliths and other radial injections some distance beyond the periphery of the stock are perfectly fresh.

The quartz-rich granitic and rhyolitic rocks, and even the quartz-poor soda syenite of Mineral Mountain, contain abundant miarolitic cavities and quartz-filled channelways testifying to the fact that fluids were escaping upward through these bodies while they were still at least partially molten.

During the volcanic phase, then, the North La Sal stock can be pictured as a partly congealed, and hence porous gaseous diffusion column, reaching perhaps from the surface to the site of magma generation in the substratum. On their way upward the streaming gases would have attacked and altered already crystallized but perhaps still hot minerals. Free silica released by the alteration processes would be carried upward in the fluids and some of it would enter the small amount of syenitic rest magma in the upper part of the stock transforming it to quartz-rich granitic or rhyolitic rocks. With continued congealing the traveling fluids precipitated bull quartz and comb quartz in open channelways and in breccia zones within the solidifying aegerine granite porphyry and in the brecciated rock of the diatremes. Ore-bearing sulfides, fluorite, and other hydrothermal products form a part of these fillings. This, together with the widespread sericitization, chloritization, and other hydrothermal effects in the rocks within and adjacent to the stocks, brings the igneous cycle to an end.

\section{SUMMARY}

To recapitulate, there is no direct evidence as to the origin and exact mechanics of evolution of the magmas, but a tentative working hypothesis may be inferred from the field relations and from physical-chemical considerations. The steps suggested are as follows:

1. Rise of temperature in the substratum leads to partial fusion of amphibolite, or related heteromorphous metamorphic rocks, producing a melt of dioritic composition intimately mingled with unfused hornblende-rich remnants of the original metamorphic series. Selective fusion probably occurred at or near the base of the crust.

2. Hydrostatic or orogenic pressures cause a mechan- ical break up of the partly fused layer, with coalescence and rise of the more fluid parts.

3. The palingenetic melt, carrying suspended unfused fragments, is physically injected toward the surface. Eventually diorite porphyry stocks penetrate to high levels in the crust with attendant doming of the surface and radial intrusion of a satellitic retinue of diorite porphyry laccoliths. Some filtration differentiation occurs during upward intrusion.

4. Continued rise of temperature in the substratum causes partial solution of considerable hornblende and biotite into the new palingenetic magma, thus changing its composition to a more alkalic and more femic liquid.

5. The new alkalic liquid rises into the stock with attendant filtration differentiation, changing the composition of the rest magma in the upper part of the stock to monzonite and then to syenite. These magmas form new composite intrusions within the stock and also a few satellitic intrusions outward from it.

6. Loss of heat in the substratum causes a cessation of palingenetic melting and the onset of crystallization.

7. Stiffening of the upper part of the stock by cooling and congealing, but continued rise of magma into the lower part of the stock, causes repeated fracturing of the roof leading to the formation of the syenitic dike-swarm complex. Strong filtration effects occur as the now nearly solid magma is forced into the fracturing roof. The final alkalic residues of crystallization are squeezed out as late feldspathoidal dikes. Locally a few veins of calcite end the cycle.

8. Continued loss of heat occurs with concomitant crystallization in the substratum and in the deeper parts of the conduits leading upward to the laccolithic complex until finally only a small fraction (perhaps 5 percent) of the magma remains fluid.

9. The rise of gas pressure due to crystallization within the magma, perhaps assisted by erosion of the domed roof, eventually blasts a series of diatremes through the top of the North La Sal stock, initiating a volcanic phase.

10. Release of pressure caused by opening of the volcanic orifices starts violent retrograde boiling in the still liquid residues within the stock. Greatly increased gas pressure due to crystallization of the palingenetic melts at depth may also send vast amounts of gases streaming upward through the stock toward the surface. 
11. The upward surging fluids change the course of differentiation. The stock and its volcanic orifices are now a long gaseous diffusion column. The streaming fluids carry upward large quantities of silica, perhaps released in part by alteration of already solidified minerals by the streaming gases. This rising silica-rich fluid mixes with and transforms the residual syenitic liquor into a quartz-rich soda rhyolite porphyry, parts of which explode violently to the surface, otber parts of which solidify in and adjacent to the roots of the volcanic diatremes as quartz-rich miarolitic soda rhyolite porphyry.

12. Crystallization of magma is completed, but gases continue to rise for a while through the hot solidified rock producing pneumatolytic and hydrothermal effects such as sericitization, chloritization, and deposition of ore minerals.

\section{ECONOMIC GEOLOGY GENERAL}

Mineral deposits in the La Sal Mountains area are of three principal kinds: deposits of metals, mostly hydrothermal, in and amongst the intrusions; gold placer deposits at the base of the mountains; bedded deposits of uranium-vanadium and of manganese in the sedimentary formations around the mountains.

The uranium-vanadium deposits in this general region are mostly in the Morrison formation and Shinarump conglomerate. They have been described by Fischer and others (Fischer, 1937, 1943; Fischer and Hilpert, 1952). Manganese oxide occurs in sandstone of the Morrison formation at the northwest edge of Bald Mesa, in the SE $1 / 4$ sec. 18, T. 26 S., R. 24 E. (Baker, Duncan, and Hunt, 1952, p. 127). These bedded deposits occurring in the sedimentary rocks were given little attention during the study represented by this report and will not be further considered here.

\section{PLACER DEPOSITS}

Gold-bearing gravel deposits have been prospected at several places on Bald Mesa and farther west on Wilson Mesa, and along Placer Creek.

The deposits along Placer Creek are bouldery glacial outwash and moraine, are little weathered, are in the bottom of Placer Creek, and are probably of Wisconsin age. A moraine in Placer Creek east of Pinhook is said to have been prospected by an adit that was driven inward nearly 1,000 feet without reaching the bedrock floor of the moraine. This adit is caved.

The gravel in the deposits on Bald and Wilson Mesas range from $1 / 2$ inch to $2 \frac{1}{2}$ feet in diameter. They are deeply weathered, are high above the present streams draining the mountain, and must be pre-
Wisconsin in age. These gravels, like those along Placer Creek, contain pebbles of soda syenite and other feldspathoidal rocks, metadiorite veined with actinolite and hedenbergite, and amethystine quartz and must have been derived from the central part of North Mountain. Thus, the deposits on Bald and Wilson Mesas not only are high above the present drainage, they now are separated from their source by a high ridge.

$$
\text { According to Hill (1913, p. 114): }
$$

The gold, said to be worth from $\$ 19$ to $\$ 20$ an ounce, occurs in small wires or flakes, and none of that seen appeared to be. much waterworn. It is distributed throughout the thickness of the deposits, which are said to be of about the same grade from the surface to bedrock. Besides the gold that can be recovered by washing, it has been found that the $* * *$ porphyry cut by quartz stringers $* * *$ contains a fairly large portion of the gold value of the gravels. Some of the miners assert that for every ounce saved by sluicing 10 ounces is lost in the $* * *$ rock which goes over the dump.

The deeply weathered pre-Wisconsin gravel deposits on the tops of the mesas should offer more promise for prospecting than the comparatively unweathered gravel deposits of Wisconsin age along the present stream courses. The weathering could be expected to increase the percentage of fines and thereby free some gold from its matrix. Weathering of sulfides could be expected to free some gold from the sulfide minerals. The suggested importance of the weathering also is strengthened by the fact that the gold in the weathered gravels, as quoted above, occurs in wires and flakes and does not appear to be waterworn, and that it seems to be as abundant in the upper part of the gravel deposit as in the lower. However, water for sluicing would be difficult to obtain on the mesa tops.

Weathered gravel similar to that on Bald Mesa occurs on the benches along Beaver Creek at the northeast foot of North Mountain. These gravels were derived from Beaver Basin and should be as promising for prospecting as those on Wilson Mesa.

The occurrence of gold in these placer deposits encourages the hope that commercial deposits of gold may occur in the central part of North Mountainthe area in and adjoining the stock-for it is the gravels from this area which have yielded the best shows of gold in the placers.

\section{METALLIFEROUS DEPOSITS IN THE INTRUSIONS}

The evidence at hand strongly suggests that the content of copper, lead, zinc, selenium, and presumably gold in the intrusions is a function of the degree and kind of hydrothermal alteration (p. 338), but the radioactivity seems to be of magmatic rather than pneumatolytic origin (p. 338). 
The radioactivity is greatest in the youngest intrusions, which are potash rich. These intrusions are mostly in the stock in North Mountain but include some of the feldspathoidal dikes that radiate from that stock. There is no evidence to suggest whether the materials responsible for the radioactivity of the stock are disseminated throughout the syenitic intrusions or are locally concentrated.

The other metals are most abundant in the zones of vertically sheeted joints that radiate from the North La Sal stock, especially in the pyritic and (or) quartzic facies, and in fissures in the stock. Although the deposits contain some silver and a little copper, their chief value probably is in their content of gold-which is thought to be mostly in the pyrite from which it is freed on oxidation. The tendency in prospecting thus far has been to drive crosscuts or drifts under the exposed parts of promising fissures or fissured zones, but some of the oxidized upper parts of the fissures or fissured zones might contain enough free gold to warrant development.

\section{MINE DESCRIPTIONS}

\section{DHLON ADIT}

The Dillon adit (pl. $45 B$ ) is at the west foot of Mineral Mountain at an altitude of almost 10,000 feet. A steep but satisfactory road has been built by the Fowler Mines from Pinhook to the portal in Miners Basin. The adit, about 1,200 feet long, is by far the largest adit in the La Sal Mountains. It is a drift along one or more zones of fissuring in the west edge of the North La Sal stock.

Judging by outcrops just south of the portal, the adit begins in sheared and pyritized diorite porphyry, but somewhere along the timbered area in from the portal, the adit enters pyritized shale beds, probably belonging to the Paradox member of the Hermosa formation. These beds are overturned so that they dip east towards the stock; they are cut by at least one reverse fault.

Two hundred feet from the portal, the adit enters metadiorite of the North La Sal stock. From here on to the breast, the adit drifts along shear zones in the porphyry. For 200 feet back from the breast, the adit exposes considerable masses of Precambrian rocks. These are plastic and claylike; large quantities of water seep from the roof in this part of the adit. $\mathrm{Nu}$ merous small blocks of Precambrian rocks show along the walls of the drift in the metadiorite in the central part of the adit.

According to reports, the shale beds near the portal contain nonauriferous pyrite, but gold-bearing pyrite occurs in the wall rocks of the adit in the metadiorite. In the sheared roof is much iron oxide, evidently due to oxidation of pyrite, and gold has been found in this oxidized rock. Some fissures are stained with copper carbonate. Quartz veins and calcite veins are not abundant.

During the fieldwork it was determined that a Geiger counter would become contaminated, apparently by radon, when taken into the Dillon tunnel. On May 1, 1952, Henry Faul, Arthur Sakakura, and I visited the adit to obtain samples of the mine gas and to test for radon. The mine had been inactive through the winter and the portal was sealed with snow. Mine air samples were taken in glass containers of two sizes, 100 and 500 cubic centimeters. A portable field laboratory was set up at Moab, Utah, and the containers were evacuated there and carried to the mine.

In the laboratory the gas samples were transferred from the bottles by expansion and flushing with nitrogen into evacuated ionization chambers of 4-liter capacity. The radon content was determined by Henry Faul. The test consisted of measuring the total equilibrium intensity of electron- and negative-ion flow in the saturated chambers with a vibrating-reed electrometer. This intensity was compared with that obtained from an amount of radon derived from a reference solution prepared and calibrated by the National Bureau of Standards.

The mean radon content of air in the Dillon tunnel was found to be about 5,000 micromicrocuries per liter at mine temperature $\left(34^{\circ} \mathrm{F}\right)$ and pressure.

A sample of water, collected at the portal, was found to contain about 625 micromicrocuries of radon per liter.

\section{I. F. ADIT}

The M. I. F. adit (pl. 45C), located on the west side of Mineral Mountain at an altitude of about 10,400 feet, is reached by trail from the portal of the Dillon adit. The M. I. F. adit is a 300 -foot drift along a shear zone in metadiorite at the west edge of the North La Sal stock, probably the same zone of fissuring as in the Dillon adit but 400 feet higher.

The walls of the adit are brecciated and hydrothermally altered metadiorite, much of which is finely veined with actinolite and (or) hedenbergite.

Between 50 and about 100 feet in from the portal, the fissured zone of pyritized and brecciated metadiorite is about as wide as the adit. From 100 to 150 feet the shear zone is only an inch wide, or at most a very few inches wide, but it is wide most of the way from the bend 150 feet from the portal to the breast. Fifteen feet from the breast, however, the shear zone is interrupted by a rib of firm, only slightly altered metadiorite. The rib ends at a vertical shear plane, with vertical slickensides.

The metadiorite is thoroughly stained with iron oxide, some of which occurs in cubes. This evidently is an 
oxidized pyritic zone. Where the metadiorite is widely sheared, gold can be panned from the crushed rock.

\section{HIGH ORE ADIT}

The High Ore adit (pl. 45D) is on the east side of Mineral Mountain, in the High Ore Basin, at an altitude of 10,900 feet. It is reached by trail from Miners Basin. The mine consists of two principal drifts along mineralized fissures at the east edge of the soda syenite porphyry on Mineral Mountain. The north drift extends about 150 feet along the footwall of a fissure in syenitized metadiorite. The hanging wall side of the fissure forms the north wall of the drift and dips between $70^{\circ}$ and $90^{\circ}$ $\mathrm{N}$. The footwall is crossed by three principal sets of fissures. One set trending N. $50^{\circ} \mathrm{W}$. is tight. The other two sets, one trending $\mathrm{N} .10^{\circ} \mathrm{E}$. and the other trending N. $40^{\circ} \mathrm{E}$., commonly contain thin veins, less than an inch wide, of quartz stained with copper carbonate. Most of these joints end against the hanging wall, but one that cuts the hanging wall is 2 feet wide.

At the portal and at the breast, the main fissure zone is 2 to 3 feet wide and consists of gouge stained with copper carbonate and lenticular openings lined with comb quartz. No doubt the openings were filled with clay gouge.

A branch of the main fissure trends south of west and has been explored by a drift about 100 feet long. Where the drift crosses the contact between the metadiorite and soda syenite porphyry the fissuring becomes tight and the copper carbonate staining ends. At the breast the soda syenite is fissured and stained with iron oxide in a zone about 3 feet wide.

The minerals observed in the main fissured zones in the High Ore mine include quartz, calcite, fluorite, chalcopyrite, pyrite, malachite, azurite, chrysocolla, hematite, limonite, goethite, and chalcedony. The wall rocks contain veins of hedenbergite and (or) actinolite. According to Hill (1913, p. 113), 7 tons of ore from the north vein is said to have brought $\$ 54$ a ton in copper, silver, and gold.

A Geiger-counter traverse of the workings showed little or no radioactivity in the metadiorite. In the part of the south drift that is in the soda syenite porphyry the Geiger counter showed counts two to three times higher than background at the portal.

\section{DEWEY ADIT}

The Dewey adit (pl. 45A), in Golden Sceptre Gulch at an altitude of 11,400 feet, is reached by trail from the head of McCormick Park which in turn is accessible by jeep. The adit, which extends slightly more than 500 feet N. $85^{\circ} \mathrm{E}$, , follows a fissured zone that cuts across the dike-swarm complex. This zone is crossed by a set of joints that trend slightly east of north and $\operatorname{dip} 45^{\circ}-70^{\circ} \mathrm{W}$. These joints occur singly at widely spaced intervals and do not form a fissure zone; only a few are mineralized. For 350 feet in from the portal, quartz veins are common although hardly abundant. Most of them trend N. $10^{\circ} \mathrm{E}$. Two of the quartz veins are 6 to 8 inches wide but most of them are less than 1 inch wide. Some of the quartz is coated with chrysocolla. Few of the veins extend from one wall to the other; most of them are cut off along the fissured zone along which the adit has been driven.

The drift is mostly in crushed and fissured soda syenite but exposes some metadiorite. About 75 feet from the face the drift crosses an explosion breccia 20 feet wide. Although the last 30 feet of the adit is in syenite porphyry, the breast may be in soda rhyolite and Precambrian rocks.

The minerals observed on the tailings dump at the portal of the Dewey adit include quartz, chalcedony, calcite, fluorite, chalcopyrite, pyrite, malachite, chrysocolla, and various iron oxides. Along the walls of the adit are sporadic masses of highly altered Precambrian rocks, mostly less than a foot in diameter, and a few veins of actinolite and hedenbergite.

The Dewey adit was opened during the nineties and was worked intermittently during the next 35 or so years. According to Hill (1913, p. 113), some of the veins are said to average $\$ 20$ to the ton in gold, silver, and copper.

A Geiger-counter traverse of the drift indicated radioactivity to the extent of about two to three times background. The mine was generally dry at the time of the traverse; at only a couple of places was there drip from the roof.

\section{MCCOY ADIT}

The McCoy adit (pl. 45E), in Beaver Basin at an altitude of about 10,640 feet, consists of an adit, shaft, and some open pits. A road leads to the mine from the road along the north foot of North Mountain.

The several openings are in what appears to be syenitized diorite porphyry at the northwest edge of a wide zone of much jointing and shearing. Syenite porphyry dikes trending southeastward parallel to the sheeted zone lie about 500 feet southwest of the mine, but none was observed in or about the openings.

The main adit is about 250 feet long. It enters along a northwestward-trending shear zone that involves porphyry and sedimentary rocks; the latter probably is the Paradox member of the Hermosa formation. Fifty feet in from the portal the shale beds dip $40^{\circ}$ to $65^{\circ}$ south of west; but they are much sheared and it is doubtful if these dips persist. Northwest of this shear zone the adit crosses into a block of little disturbed and only moderately altered porphyry. Even where the 
porphyry is not brecciated or much jointed it is bleached and has lost its femic minerals.

Thin veins of quartz, some stained with copper carbonate, and thin veins of bornite and chalcopyrite were observed along some of the fissures in the sheared porphyry. At the portal is a vein of calcite about 6 inches wide, but not much calcite was observed along the adit.

Water seeps from the roof of the adit along the shear zone near the breast; the rest of the tunnel was dry at the time of the survey.

At several places along the adit the hanging wall of the fissure zone is a plane sharply separated from brecciated and fissured porphyry making up the footwall. Slickensiding on the hanging wall parallels the dip.

The shaft, judged to be about 25 feet deep, was not surveyed. It is 100 feet higher than the adit and about 300 feet to the northwest. It is reported to connect by a crosscut with an adit about 50 feet southeast of the shaft.

Small amounts of gold and silver-bearing copper ore reportedly have been produced from the McCoy mine. A Geiger counter taken a short distance into the adit behaved erratically, as if the air contained radon.

List of some mine openings in and near the North La Sal stock [Length of caved openings based on reports from local people; see pl. 40 for location of openings]

1. Dillon adit, Fowler Mines; adit 1,200 feet long (pl. 45B).

2. M. I. F. adit (south); 290 feet long (pl. $45 \mathrm{C}$ ).

3. M. I. F. adit (north); 40 feet (caved); in metadiorite and Precambrian.

4. Double Standard shaft; depth 44 feet; partly caved; in soda syenite porphyry.

5. Double Standard adit; 50 feet(?), caved; in metadiorite and Precambrian.

6. Florence No. $1 ; 180$-foot adit and 60-foot side drift; entranoe caved; in metadiorite and Precambrian.

7. Florence No. 2; 90-foot adit; entrance caved; in metadiorite and Precambrian.

8. Newberg adit; 25 feet long; in metadiorite. Not shown on map; exact location not determined; near 6, 7 .

9. Wheat adit (lower level), 120 feet long; entrance caved; in diorite porphyry with pyritic alteration.

10. Wheat adit (upper level), 35 feet long; entrance caved; in diorite porphyry with pyritic alteration.

11. High Ore adit (pl, $45 D$ ).

12. West Slope crosscut; 290 feet long; entrance caved; in diorite porphyry with pyritic alteration. See Tornado No. 1 (no. 14).

13. West Slope incline; 25 feet long; in diorite porphyry with pyritic alteration. See Tornado No, 1 (no. 14).

14. Tornado No. 1; 40-foot adit; entrance caved; in diorite porphyry with pyritic alteration. According to Hill (1913, p. 112): "The Tornado property has been worked to more advantage than any of the other properties in [Miners] Basin. Two zones of fracturing intersect near the main workings; one, the Tornado vein strikes N. $80^{\circ} \mathrm{E}$., and the other, the Indiana, strikes N. $40^{\circ} \mathrm{E}$. Along these zones there are numerous branching fractures filled with dark glassy drusy quartz up to three-fourths of an inch in width. Near the junction of the two systems the interlacing seams are more abundant. Pyrite has been deposited both with the quartz and disseminated in the altered monzonite porphyry wall rock. The Indiana zone averages about 10 feet in width and the Tornado from 15 to 20 feet. The former is opened by two short tunnels and the latter near its junction with the Indiana by a tunnel and a 50-foot shaft. A crosscut tunnel, now 270 feet long, has been started for the intersection but [West Slope crosscut?] has not yet reached it. All the altered pyrite-impregnated $* * *$ porphyry cut by quartz stringers is classed as ore, with a reported average value of $\$ 15$ to $\$ 20$ a ton in gold. It is all oxidized, and only a few pyrite crystals remain unchanged to limonite. The material pans well, but it is said that the iron concentrates, made at the mill, ran $\$ 28$ to the ton in gold."

15. Tornado No. 2; inclined shaft 30 feet long; entrance caved; in diorite porphyry with pyritic alteration. See Tornado No. 1.

16. Indiana adit; 60 feet long; entrance caved; in diorite porphyry with pyritic alteration. See Tornado No. 1.

17. Leland No. 1 ; 65 -foot adit, entrance caved; mostly in colluvium, some diorite porphyry with pyritic alteration and may extend into syenite porphyry dikes.

18. Leland No. 2; 80-foot adit, entrance caved; mostly in colluvium, some diorite porphyry with pyritic alteration and may extend into syenite porphyry dikes.

19. Beibush adit; 65 feet long; entrance caved; pyritic altered diorite porphyry and possibly syenite porphyry dikes.

20. Bryant opencut; 35 feet long; caved; in pyritic altered diorite porphyry.

21. Ice cave; 480 -foot adit, filled with ice; mostly in diorite porphyry.

22. McCormick adit; 120 feet long; entrance caved; a drift along contact at side of feldspathoidal dike. According to Hill $(1913, p .112)$ : "This vein is not very well defined and is nowhere over 21 inches wide. The vein material is calcite, siderite, and a little fine quartz, partly filling the fracture, which in a few places shows stains of copper carbonate."

23. Alamo adit; 65 feet long; entrance caved; probably crosses syenite porphyry dike and may extend into explosion breccia.

24. Dewey adit (pl. $45 \mathrm{~A}$ ).

25. Upper Dewey adit; 35 feet long; drift along fissured dike wall in dike swarm.

26. Lower Dewey adit; 100 feet long; in soda syenite porphyry of dike swarm.

27. Skylark No. 1; 205-foot adit; entrance caved; in soda syenite porphyry. According to Hill (1913, p. 112), the Skylark No. 1 and No. 2 (see below, no. 28) "expose a vein varying from knife-blade thickness to 2 feet. This vein euts both monzonite porphyry and a dike of syenite porphyry. It strikes $\mathrm{N} .52^{\circ}$ E. and stands nearly vertical. In its wider portions there is an abundance of glassy dark quartz with drusy cavities. Some of these druses are coated with greenish-blue chrysocolla, much of it dull and earthy. Masses of limonite, usually copper bearing, which are probably the alteration products of cupriferous pyrite or chalcopyrite, occur in the quartz. Narrow quartz stringers make off into the porphyry, which contains some disseminated pyrite near them."

28. Skylark No. 2; 35-foot adit; entrance caved; in quartzveined soda syenite porphyry. 
29. Venus adit; 50 feet long; in dike swarm.

30. Little Dot adit; 150 feet long; mostly metadiorite; may cut some syenite porphyry dikes.

31. McCoy adit (pl, 45E).

32. Shaft; 25 feet deep, in sandstone of Glen Canyon group; in sec. 3 (projected) T. 26 S., R. 24 E.

33. Johnson shaft; 80 feet deep, mostly in rounded gravel, glacial outwash, but bottoms in Mancos shale; on Bald Mesa, near center sec. 19, T. 26 S., R. 24 E. Gravel derived from North La Sal stock includes soda syenite, vent breccia, and soda rhyolite.

34. Crystal adit, in fissure in soda syenite; north side of Mineral Mountain.

Some other openings are shown on the map (pl. 40), but either they are small or their extent is unknown.

\section{SELECTED BIBLIOGRAPHY}

Baker, A. A., 1933, Geology and oil possibilities of the Moab district, Grand and San Juan Counties, Utah: U. S. Geol. Survey Bull. 841.

— 1935, Geologic structure of southeastern Utah: Am. Assoc. Petroleum Geologists Bull., v. 19, p. 1472-1507.

Baker, A. A., Duncan, D. C., and Hunt, C. B., 1952, Manganese deposits of southeastern Utah: U. S. Geol. Survey Bull. 979-B.

Baker, A. A., and others, 1927, Notes on the stratigraphy of the Moab region, Utah: Am. Assoc. Petroleum Geologists Bull., v. 11, p. $785-808$.

Bowen, N. L., 1922, The behavior of inclusions in igneous magmas: Jour. Geology, v. 30, p. 513-570.

—_ 1928, The evolution of the igneous rocks: Princeton, N. J., Princeton Univ. Press, 332 p.

Butler, B. S., 1920, The ore deposits of Utah: U. S. Geol. Survey Prof. Paper 111.

Cater, F. W., Jr., 1953, Geology of the Gypsum Gap quadrangle, Colorado: U. S. Geol. Survey quadrangle map GQ-59, scale, $1: 24,000$.

Clarke, F. W., 1904, Analyses of rocks from the laboratory of the United States Geological Survey 1880-1903: U. S. Geol. Survey Bull. 228.

Clarke, F. W., and Hillebrand, W. F., 1897, Analyses of rocks, with a chapter on analytical methods, Iaboratory of the United States Geological Survey, 1880 to 1896: U. S. Geol. Survey Bull. 148.

Cross, C. W., 1894, The laccolithic mountain groups of Colorado, Utah, and Arizona: U. S. Geol. Survey 14th Ann. Rept., pt. 2, p. 152-241.

Cross, C. W., and Spencer, A. C., 1900, Geology of the Rico Mountains, Colo.: U. S. Geol. Survey 21st Ann. Rept., pt. 2, p. 7-165.

Cross, O. W., Spencer, A. C., and Purington, C. W., 1899, Description of the La Plata quadrangle [Colorado]: U. S. Geol. Survey Geol. Atlas, Folio 60 [1901].

Dane, C. H., 1931, Uncompaghre Plateau and related structural features: Washington Acad. Sci. Jour., v. 21, p. 28.

_ 1935, Geology of the Salt Valley anticline and adjacent areas, Grand County, Utah: U. S. Geol. Survey Bull. 863.

Eckel, E. B., 1937, Mode of igneous intrusion in La Plata district Colo.: Am. Geophys. Union Trans., pt. 1, p. 258-260.

1949, Geology and ore deposits of the La Plata district, Colorado: U. S. Geol. Survey Prof. Paper 219.
Emery, W. B., 1916, The igneous geology of Carrizo Mountain: Am. Jour. Sci., v. 42, p. 349-363.

Fischer, R. P., 1937, Sedimentary deposits of copper, vanadium, uranium, and silver in southwestern United States: Econ. Geology, v. 32, p. 906-951.

1943, Vanadium deposits of Colorado and Utah, a preliminary report: U. S. Geol. Survey Bull. 936-P.

Fischer, R. P. and Hilpert, L. S., 1952, Geology of the Uravan mineral belt: U. S. Geol. Survey Bull. 988-A.

Gilbert, G. K., 1877, Report on the geology of the Henry Mountains [Utah]: U. S. Geol. and Geog. Survey Rocky Mountain region (Powell).

Gilluly, James, 1927, Analcite diabase and related alkaline syenite from Utah: Am. Jour. Sci., 5th ser., v. 14, p. 199-211.

Gould, L. M., 1925, A "laccolith in the air" [La Sal Mountains]: Michigan Acad. Sci. Papers, v. 5, p. 253-256.

_- 1925, Petrography of some Sierra La Sal dikes [abs.]: Pan-Am. Geologist, v. 44, 2, p. 158.

1926a, The Geology of La Sal Mountains of Utah: Michigan Acad. Sci. Papers, v. 7, p. 55-106.

- 1926b, The role of orogenic stresses in laccolithic intrusions: Am. Jour. Sci., 5th ser., v. 12, p. 119-129.

Harrison, T. S., 1927, Colorado-Utah salt domes: Am. Assoc. Petroleum Geologists Bull., v. 11, p. 111-133.

Hill, J. M., 1913, Notes on the northern La Sal Mountains, Grand County, Utah: U. S. Geol. Survey Bull. 530, p. 99-118.

Holmes, W. H., 1877, Report on the San Juan district, Colorado: U. S. Geol. and Geog. Survey Terr. 9th Ann. Rept., p. 237276.

1878, Report on geology of the Sierra Abajo and west San Miguel Mountains: U. S. Geol, and Geog. Survey Terr. 10th Ann. Rept., p. 189-196.

Hunt, A. P., 1953, Archeological survey of the La Sal Mountain area, Utah: Univ. Utah Anthropol. Paper 14, 248 p.

Hunt, C. B., 1938, Igneous geology and structure of the Mount Taylor volcanic field, New Mexico: U. S. Geol. Survey Prof. Paper 189-B, p. 51-79.

1_ 1953, Geology and geography of the Henry Mountaing region, Utah: U. S. Geol. Survey Prof. Paper 228.

1956, Cenozoio geology of the Colorado Plateau: U. S. Geol. Survey Prof. Paper 279.

Hunter, J. F., 1925, Pre-Cambrian rocks of Gunnison River, Colo.: U. S. Geol. Survey Bull. 777.

Macdonald, G. A., 1949, Hawaiian petrographic province: Geol, Soc. America Bull. 60, p. 1541-1596.

Peale, A. C., $1877 \mathrm{a}$, On a peculiar type of eruptive mountain in Colorado: U. S. Geol. and Geog. Survey Terr. Bull. 3, p. 550-564.

1877b, Geological report on the Grand River district: U. S. Geol. and Geog. Survey Terr. 9th Ann. Rept.

1878, Geological report on the Grand River district: U. S. Geol, and Geog. Survey Terr. 10th Ann. Rept., p. 163-182.

Prommel, H. W. C., 1923, Geology and structure of portions of Grand and San Juan Counties, Utah: Am. Assoc. Petroleum Geologists Bull., v. 7, p. 384-399.

1927, Salt domes, fractures and test wells in southeast Utah: Oil Weekly, v. 45 , no. 11 , p. 41.

Prommel, H. W. C., and Crum, H. E., 1927a, Salt domes of Permian and Pennsylvanian age in southeastern Utah and their influence on oil accumulation: Am. Assoc. Petroleum Geologists Bull., v. 11, p. 373-393. 
Prommel, H. W. C., and Crum, H. E., 1927b, Structural history of parts of southeastern Utah from interpretation of geologic sections: Am. Assoc. Petroleum Geologists Bull., v. 11, p. 809-821.

Robinson, H. H., 1913, The San Franciscan voleanic field, Arizona: U. S. Geol. Survey Prof. Paper 76, p. 74-85.

Thorpe, M: R., 1919, Structural features of the Abajo Mountains, Utah: Am. Jour. Sci., 4th ser., v. 48, p. 379-389.
1938, Structure of the Abajo Mountains, in Gregory, H. E., The San Juan country, a geographic and geologic reconnaissance of southeastern Utah: U. S. Geol. Survey Prof. Paper 188, p. 89-91.

Wager, L. R., and Deer, W. A., 1939, The petrology of the Skaergaard intrusion, Kangerdlugssuaq, East Greenland: Medd. om Grønland, v. 105, no. 4, 352 p.

Williams, Howel, 1936, Pliocene volcanoes of the Navajo-Hopi country: Geol. Soc. America Bull., v. 47, p. 111-172. 


\section{INDEX}

Acknowledgments

Adits:

Dillon.

Dewey.

High Ore

$\mathrm{MeCoy}$

M. I. F.

Placer Oreek

Aegirine granite porphyry of North La SaI stock

Alkali content of differentiation sequence in North Mountain................ 349

Ammonite Iragments in Mancos shale....... 343

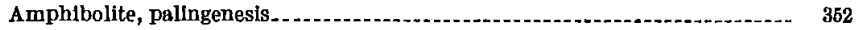

Antlolines, Castle Creek faulted salt_-_._._...... 316

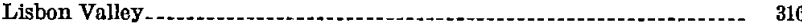

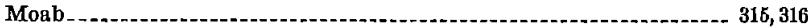

North La Sal stock.-. 318

Onion Creek.

Spanish Valley.

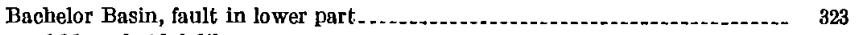
feldspathoidal dike across_.................... 328 vent breccia.

vertically shested joints.

332; pl. 40

Bear Oreek, diorite porphyry dike along west side $\ldots \ldots \ldots \ldots \ldots \ldots$

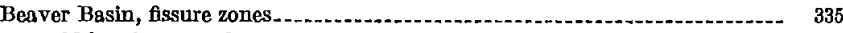

gold-bearing gravels

MeCoy adit............... 357-358, 359; pl, $45 E$

Beaver Creek, gold-bearing gravels ........ 355

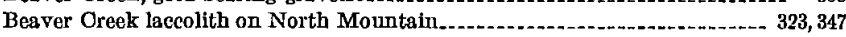

Blue Lako.

343; pl. 39

Blue Lake laccolith on Middle Mountain

Boren Mesa, Mlll Creek slll.......................... 318, 322

Bowen, N. L., quoted ....................... 352, 359

Breccias, explosion....................... 319, 324, 325, 328, 331-333, 334, 335, 345, 353, 357

Brumley Creek

Brumley Oreek laccolith on Middlo Mountain, description.-.-.-.-.- 340, 341, 347

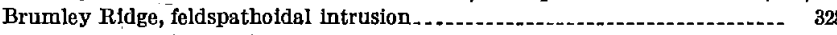
noselite syenite porphyry.................................................... 340,

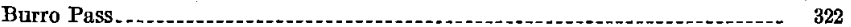

Calcium oxide, source.

Carmel formation.

(312, 315,316, 325

Castle Valley, conglomerate............... 309, 314, 315, 323 Round Mountain bysmalith..................................... 312, 323; pl. 39

Cheinical analyses, aegirine granite porphyry of North La Sal stock .._._._. 332 dike-swarm complex rocks in North $\mathrm{La}$ Sal stock.......................... $\quad 327$ diorite porphyry from laccolithic mountains on Colorado Plateau ......... 321 monzonite porphyry, Henry Mountalos................................... 324

La Plata Mountains.......... 324

La Sal Mountains.

noselite syenite porphyry .......................... 328

soda rhyolite porphyry dikes in North La Sal stock

soda syenite porphyry of North La Sal stock

Chinle formation, deseription

Cirques........................................................... 320, 342, 343, 344, 346

Colorado Plateau, chemical analyses of diorite porphyry from laccollthic mountains.-................ 320, 321

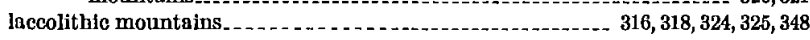
Conglomerate, in Castle Valley, description ........................ 309, 314, 316, 323 between Battle-ground and Harpole Mesa
Page
Cutler formation. Dakota sandstone . . . . . . Dark Canyon, Mount Peale laccolith on Middlo Mountain................... 342, 343 Deep Creek, diorite porphyry mass laccolith........ 345,346 zone of fissuring . ................................. 335 Description of area Dewey adit_............. 367, 358; pl. $45 \mathrm{~A}$ Diatremes, North La Sal stock.

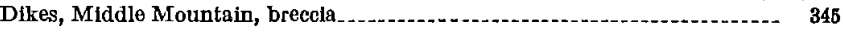
feeder-

North La Sal stock, feldspatholdal..._..._._. 319, 328, 331, 332, 353, 354, 356, 358 soda rhyolite porphyry

North Mountain, monzonite porphyry soda syenite. ......... 323 Dike-swarm complex in North La Sal stock area $320,326-328,331,333,334,335,337,338,353,354,357,358,359$; pl. 40 chemical analysis ................. 327 volume Dike swarm of syenite porphyry rocks in North La Sal stock .......... 319 , $327,357,358,359 ; \mathrm{pl} .40$
Dillon adit Diorite porphyry intrusions, metal content......... 366, 368; pl. $45 B$ Middle Mountain North Mountain. petrography

South Mountain

statistical study Diorite porphyry laceoliths of North Mountain

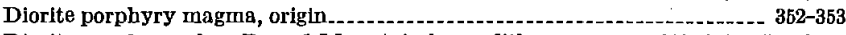
Diorite porphyry plug, Round Mountain bysmalith Diorite porphyry stock, North La Sal_._-_._....... 319, 325-326, 334, 335, 337; pl. 40 Dome, Middle Mountain ............. 316, 318, 339-340 North Mountain. . South Mountaln $\ldots \ldots \ldots \ldots, 316,345,346$ Dorry Canyon laccolith on Middle MountaIn, description._........- 338, 340, 341, 347 feeder dikes.........- 340, 343 Dry Fork of Mill Creek, zone of vertically sheeted joints

\section{$\mathbf{E}$}

East Pole Canyon, intrusions.-1.-1 345-346 Economic geology ........... Ellen, Mount, stock................. 325-326, 334 Ellen, Mount, stock
Entrada sandstone, description. Esearpment along La Sal Creek

35 Feldspars, alteration Feldspathoidal intrusion on Brumley Ridge Ferron sandstone member of Mancos shale Fissures in North La Sal stock._._.

Flow banding, dike-swarm complex............. 326 monzonite porphyry Folds, description... . Fowler Mines. Frectures................... 330, 334, 358

G

等

Middle Mountain stook 
Gold Creek, dlorite porphyry.

Golden Scoptre Gulch, Dewey adit.

Grand Vlew Mountain leccoliths on North Mountain _....... 315, 322, 329

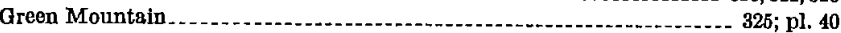

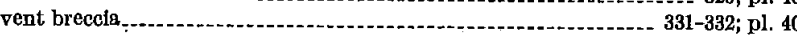
Gryphaed newberryl ................... 343

Gunnison River region, Precambrian rocks

Harpole Mesa

Haystack Mountain laccolith, North Mountain

Hell Canyon ...................... 341, 342 limestone beds of Morrison formation Hell Creek. Henry Mountains............-. 316, 318, 320, 321, 322, 324, 325, 326, 346, 348, 349, 352, 353 Hermose formation, descriptlon _... _ 311,312 Paradox member............................ 309, 311-312, 315, 318, 320, 322, 323, 334

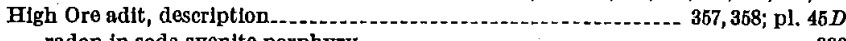
radon in soda syenlte porphyry High Ore Basin, soda syenite porphyry Hill, J. M., quoted

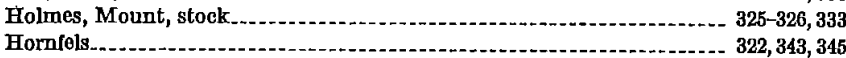
Horse Canyon, breccis dike in Middle Mountain stock

Dakota sandstone .... 313, 346

Mount Mellenthin, intruslons south laccolith. -

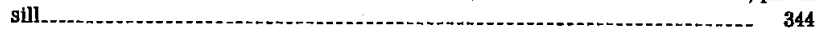
Horse Mountain laccoliths, North Mountnin ............................ 322-323 Houston, J. R., quoted.

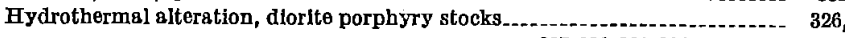

Mount Pennell stock, 330, 331, 334-335, 343, 344, 346

Introduction......
Intruslons, metalliferous deposits
rock formations cut by
sequence.

summary of dimenslons, volume, and stratigraphlc positions.............. 347 North La Sal stock.

$\mathbf{K}$

Kayenta formation, description.

$\mathbf{L}$
$310,312-313$

Laccoliths, between Wet Fork and Placer Oreek, North Mountain. Mancos shale....................... 317, 318-310, 322, 323, 334, 339-340, 343, 344 Middle Mountain, Blue Lake._._................................. 343, 344, 347 Brumley Creek.

Dorry Canyon.

Mount Mellenthin

$340,341,347$

Mount Peale.

$338,340,341,343$

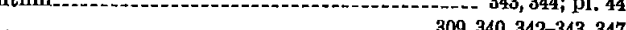

Mount Tukuhnikivatz....... 340, 341, 342

Morrison formation........................................ 318-319, 334, 340, 341, 342, 343-344

North Mountain, Grand Vlew Mountain........................ 315, 322, 323 Haystack Mountain

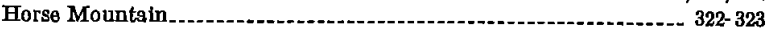

Oregon Park

North Mountaln stock, northeast_-

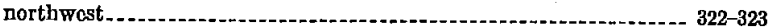

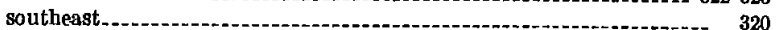

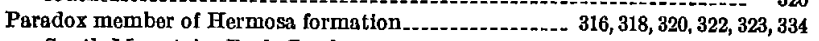
South Mountain, Pack Oreek. southeast of stock

Lackey Basln, Bouth Mountain stock. . ....................................... 346

La Plata Mountains

La Sal Oreek, intruslons at head........... 341-342

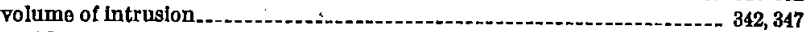

Lisbon Valley, faulted anticline

\section{$\mathbf{M}$}

MeCormlek Park, feldspatholdal dike across quartz veins ........... 337 trall.

vent breccla 332; $\mathrm{pl}, 40$
McCoy adit............. Page Magmas, evolution and origin M. I. F. adit. M. I. F. adit_._Mancos shale, ammonite fragments............................................. 343 description... Ferron sandston $\theta$ member

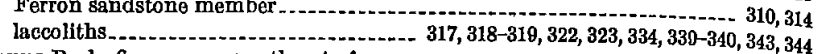

Manns Peak, fissure zone northeast of

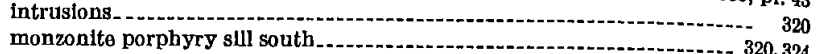

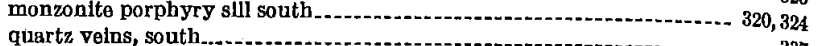
quartz veins, south .................. 337 soda rhyolite dlke-_. 337

Mapping of area-_ant, laccoliths
Mellenthin, Mount

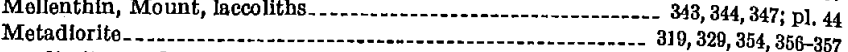
diorite porphyry stook, xenoliths..

Metalliforous deposits in intrusions.

Metals:

copper

distribution

gold -

lead.-...- 338, 365

selenium

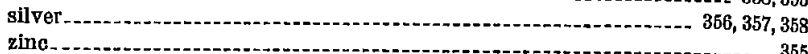

Middle Mountain, Brumley Ridge noselite syenite porphyry

dikes, breccin, in Horse Canyon............ 345

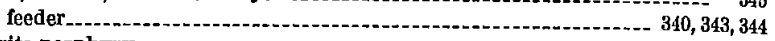

dlorite porphyry.-....... 340, 343; pl. 39

dome

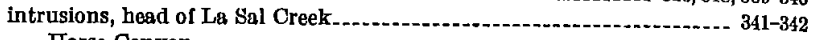

Horse Canyon ............. 344

volume-_._-_.

lnccoliths, Blue Lake.............. 343, 344, 347

Brumloy Oreek..................................................... 340, 341, 347

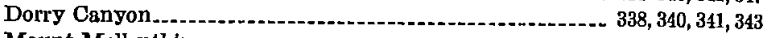

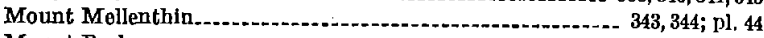

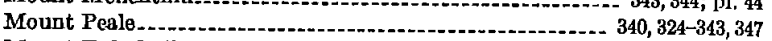

Mount Tukuhnikivatz........................................... 340, 341, 342

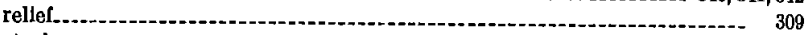

stock... 316, 318, 339, 340, 344-345, 347; pl. 44

structure

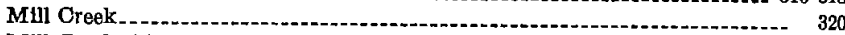

Mill Creek slll in North Mountain .

Mine descriptions.

Mine openings, list.

Mineral composition of dlorite porphyry of North La Sal stock

Mineral deposits..................... 355-356

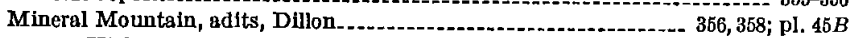

High Ore -

M. I. F........ 356-357, 358; pl. $45 C$

bull quartz and quartz veins........................ 337

North La Sal stock

sode syenite porphyry

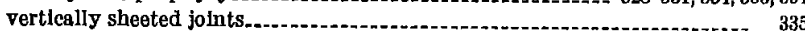

Minerals:

actinolite.

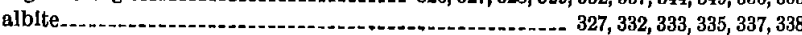

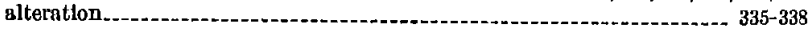
anorthoclase.-.-.- 320 apatite-

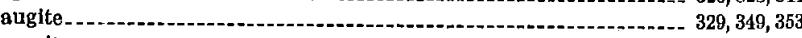
azurite biotite-_.....-_.............................. 326, 327, 329, 330, 350-351, 362, 354 calcite

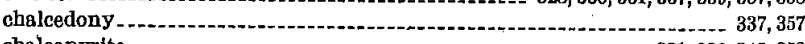

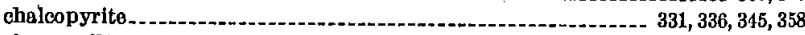

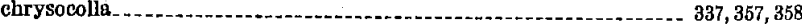

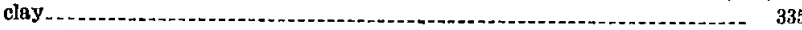
diopside epidote. ........... 326, 330, 335, 336, 339, 345, 350-351 feldspar............ 350-351, 354

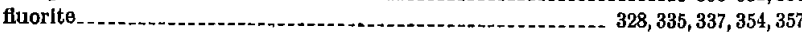
garnet. goethite hedenbergite

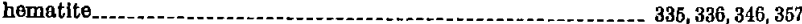
lornl)lende ......................... 326, 330, 395, 336, 339, 345, 349, 360-351, 352, 353, 354 
Minerals-Continued

(1)

megnetite $\ldots . . . .538,330,335,336,344$

malachite

microcline _._.

muscovite 328

noselite_............. 344

oligoclase.......... 327, 333, 337, 338

orthoclase . . .

perthlte _ $327,328,329,333,335,337,338,344$

pyrite. . . .

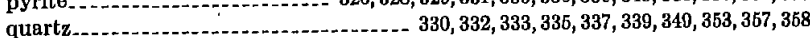
bull. _. . ................ 332, 337, 354 comb...... 331, 332, 337,354

smoky smoky rutile. sericite. . . . siderite

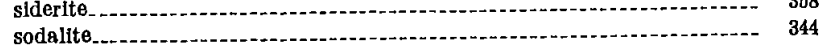
specular hematite........... 326, 330, 336, 338, 345 sphene. suliur

suliur

volume

Tornado property

$$
\text { trall }
$$

Moab anticline, description........................... 315, 316 Moenkopl formation, description $. . . . . . . .310,312,314$ Monzonite porphyry, Manns Peak, sill south

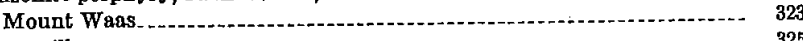
sill.

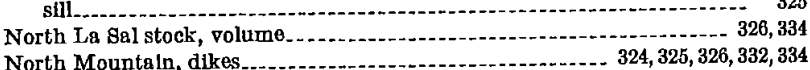

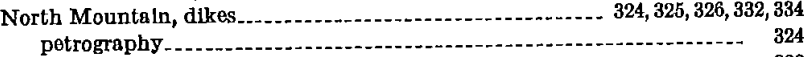
petrography

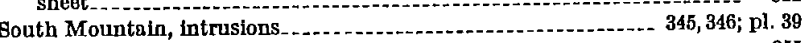

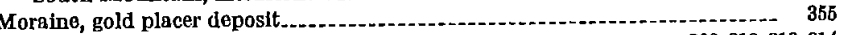

Morrison formation, deseription. . .................................... 309, 310, 313, 314 escarpment along La Sal Creek laccoliths. manganese oxlde deposits............ 365 sillis

uranlum-vanadium deposits.

\section{$\mathrm{N}$}

Navajo sandstone, description

North La Sal stock, aeglrine granite porphyry anticline.

area covered.

chemical analyses, aegirne granite porphyry

dike-swarm complex

sada rhyolite porphyry dikes.

soda syenite porpbyry

diatremes.

dikes, feldspathoidal. soda rhyollte porphyry

dike-swarm complex..

$309,310,312-313$

$319,331-333,347$

diorito porphyry.$331,333,334,335,337,338,347,353,354,357,358,369 ;$ pl. 40

fissures. 19, 325-326, 334, 335, 337, 347; pl. 40

general reatures.

356,357

mineral composition of diorlte porphyry.

$325 ; \mathrm{pl}, 40$

petrography, aegirine granite porphyry.

soda rhyollte porphyry dikes.

soda syenite porphyry.

$325-326$

- $\quad 333$

sheets of aphantic lavallke rook

329-330

319, 328-331

structural history

syenite porphyry dike swarm........................ 319, 327, 357, 358, 359; pl. 40

topography . . .

volumo....

325,347

North Mountain, dikes, monzonite porphyry _..................... 324, 325, 326, 332, 334 soda syenite.

$315, \mathbf{3 1 6}$

dome.

gold placer deposits

intruslons, volume.

laccoliths

Beaver Creek.
North Mountain-Continued

laccollths-Continued Pag6

between Wet Fork and Placer Creek $\quad \mathbf{3 2 0}$

diorite porphyry .

Grand View Mountain

Haystack Mountein........................................ 318, 319, 322

Horse Mountain

northeast of stock

northwest of stock

Oregon Park.

Paradox member of Hermosa formation, southwest of stock

southenst of stock

southwest of stock

petrography, diorite porphyry

monzonite porphyry

quartz veins in diorite porphyry

relief _ _............. 309

rock alteration

Round Mountain bysmalith.

sheets, monzonite porphyry

sills, Mill Creek. monzonite porphyry...... 320, 324, 334, 335

Mount Wass
Placer Creek.

stock

See also North La Sa] stock.

structure

Noselite syenite porphyry, Brumley Ridge ............................... 340, 344

o

Onion Creek anticline, faulted

Oregon Park, diorite porphyry laccolith in Paradox member of Hermosa formation, North Mountain

zone of vertlcally sheoted jolnts

\section{$\mathbf{P}$}

Pack Creek.

Pack Creek
sills at head.
Pack Creek lacolith on South Mountain

Pountain

Creek syncline, descriptlon . . . .

Panama vent breccia

Paradox member of Hermosa formatlon, description ............... 309, 311-312, 315 laccoliths, diorite porphyry at Oregon Park, North Mountain........ 320, 322

North Mountain stock......... 334

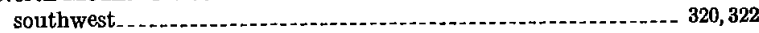
salt plugs Paradox Valley, faulted belt. Peale, Mount, altltude.
$\quad$ laccolith...

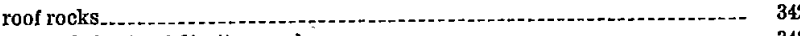
vertical sheets of dtorite porphyry

Pennell, Mount, chemical analysis of monzonite porphyry hydrothermal alteration . . .

Petrography, aegirine granite porphyry of North La Sal stock . . ............ 332-333 diorite porphyry of North Mountain........ 319-320 monzonite porphyry of North Mountain

soda rhyolite porphyry dikes in North La Sal stock

soda syenite porphyry on Mineral Mountain. ........................... 329-330

Pilot Mountain, hydrothermal alteration in vicinity monzonite porphyry dike north................ 325; pl. 40 quartz and bull quartz veins............... 337 vertically sheeted joints.

Placer Creek adit monzonite porphyry sill

Placer deposits, gold-bearing

Pleistocene deposits

Precambrian complex, description

Precambrian schist.

Present investigation. ............................. 307

Prevlous investigations_:

Quartz veins. See Veins.

353-354

R

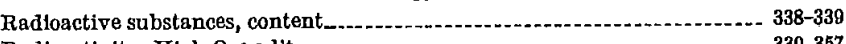

Radioactivity, High Ore adit.....

MoCoy adit .

Radon in soda syenite porphyry

Rico formation, description............................................ 3116 
Rockslides of noselite syenite porphyry on Brumley Ridge. Round Mountain bysmalith in Castle Valley

Salt beds in Spanish Valley-Pack Creek synclines $314,320,323,324,334$ Salt plugs in Paradox member of Hermosa formation . . . . . . . . San Juan Mountains, Precambrian rocks. ................................ 311 San Rafael group.......... 309,310 Schuman Canyon, gone of vertically sheeted joints $\ldots \ldots \ldots$ Schuman Gulch, belt of altered sheeted rocks. Sheets, aphanitic lavalike rock in North La Sal stock diorlte porphyry, Mount Pealo monzonite porphyry, North Mountain.

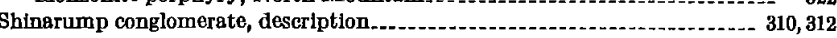
uranium-vanadium deposits......................................... 355

Sllica content of differentiation sequence in North Mountain._._. 349, 353 Sills, altered basalt in Henry Mountain ...... east rim of Whlow Basin Horse Canyon.

Mill Creek in North Mountain monzonite porphyry $\ldots$ Mount Waas.
Morrison formation......... Placer Creek in North Mountain South Mountain south of Manns Peak

Sinbad Valley, faulted belt__._. $\quad 316$ Snowsllde Gulch, Mineral Mountain, soda syenite porphry Soda rbyolite porphyry dikes in North La Sal stock, alteration of feldspar.-.- 338

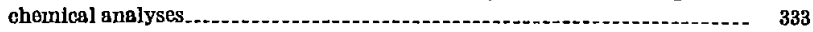
intrusion.

petrography Soda syenite dikes, North Mountain Boda syentte porphyry, Green Mountain, vugs in vent breccia Mineral Mountain, petrography veins, bull quartz_........ 330, 337, 354, 357 smoky comb quartz_....... 330, 337, 354, 357

North La Sal stock volume_..._. 328 vugs_-_..-... 330 xenoliths ............... 330

petrography -

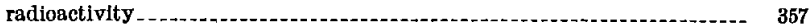

radon _ 339, 356, 358

Sodalite syenite porphyry on Brumley Ridge. See Noselite syenite porphyry.

South Beaver vent breccia..........-. 324, 330, 332

South La Sal stock. See South Mountain, stock.

South Mountain, dome $-315,316,345,346$

intrusions, diorite porphyry $\ldots \ldots \ldots$ monzonlte porphyry northeast of stock

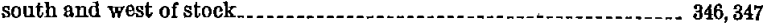
volume

laccoliths, Pack Oreek. southeast of the stock

peak, altitude........ 346

sills

stock syncline................... 318 structure

Spanish Valley anticline

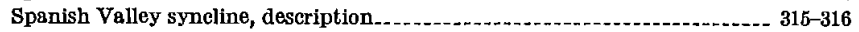

Stocks, Henry Mountains . . . _..._._. Middle Mountain. ........................... 316, 318, 339, 340, 344-345; pl. 44 North La Sal diorite porphyry _._.............. 319, 325-326, 334, 335, 337; pl. 40

North Mountain. South Mountain..... 312, 316, 318, 326, 345, 346 Stratigraphy

Structural geology
344

Structural history of North La Sal stock Page

327, 333-334

Summary _.
Summerville formation.

Syenite porphyry, dike swarm in North La Sal stock.... 319, 327, 357, 358, 359, 313 metal content................... 338

Synclines, faulted salt Pack Creek......... 316 South La Sal stock . Spanish Valley.

\section{$\mathbf{T}$}

Tomasaki, Mount, zone of vertically sheeted joints $\ldots$.
'Topography

Tomasaki, Mount, zone of vertically sheeted joints
Topography_... Topography
Tornado Basin, zone of vertically sheeted joints

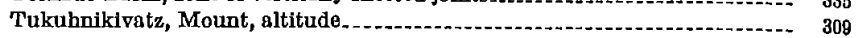
joints laccolith

\section{U}

Uncompaghre Plateau, Precambrian rocks , uplift. Uncomformity between Dakota and Morrison formations Uranium-vanadium deposits in the Morrison formation and Shinarump conglomerate.

\section{$\mathbf{v}$}

Veins:

actinolite.

bornite.

calcite ............ 358 chalcopyrite epidote

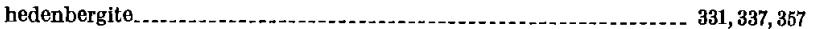

hematite

pyrite

quartz_............. 320, 332, 336, 337, 354, 356, 357

and calcite . .

bull smoky specular hematite............ 336 Vent Breccias:

Bachelor Basin..... Green Mountain....... 331-332; pl. 40 McCormlck park.

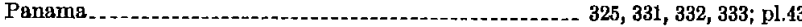
South Beaver.............................. 324, 330, 332 West Beaver Volume of intrusions, Henry Mountains._. La Sal Mountains, summary _._._. monzonite porphyry in North La Sal stock Placer Creek sill in North Mountain Vugs in soda syenite porphyry, Green Mountain vent breccla North La Sal stock ......... 330

Waas, Mount, monzonite porphyry

325

Warner Ranger Station.... 330 West Beaver vent breceia.......... 332, 333; pls, 40, 43 West Pole Canyon, Intrusions Wet Fork . . . .

Willow Basin, sill at east rim

Wilson Mesa, gold-bearing gravel deposits

Wingate sandstone, description ..................................... 309, 310

$\mathbf{X}$

Xenoliths metadorite of diorite porphyry stock soda syenite porphyry in North La Sal stock . . . . . . . . . 